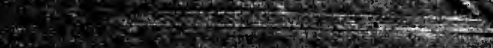

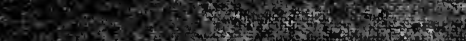

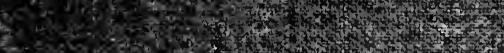

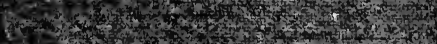

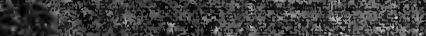

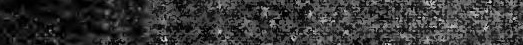

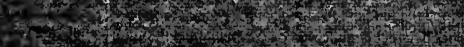

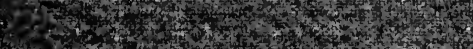

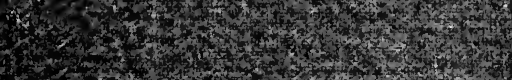

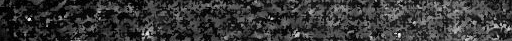
S. 2.

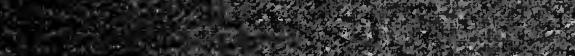
C.

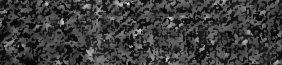

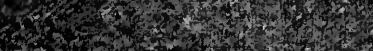
(2.

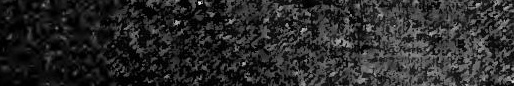

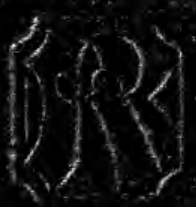

3.

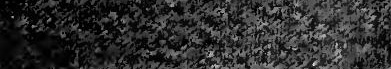
s. (n)

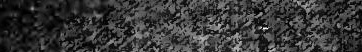

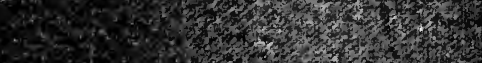

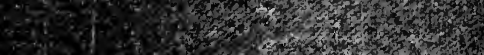

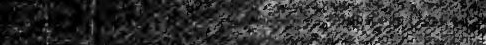
6. 3.

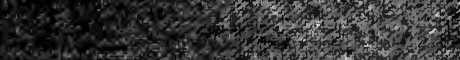

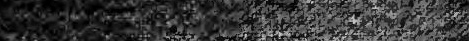

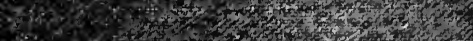
Hi

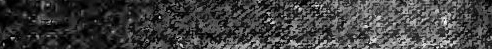

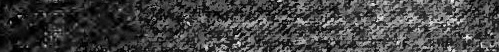

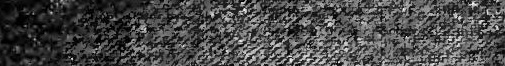

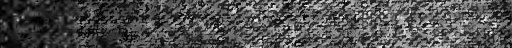

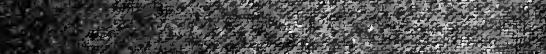

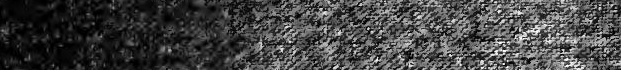

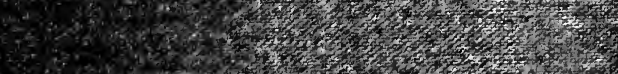

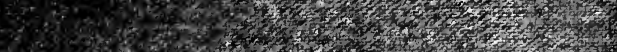

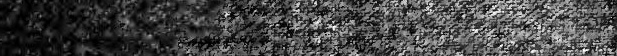
13. 30.6

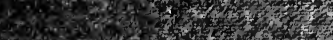

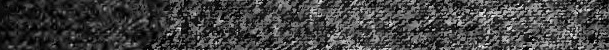
S.T. 


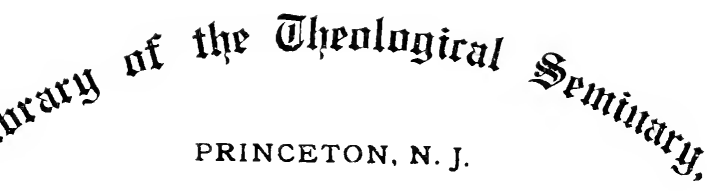

,

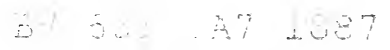

Arritage, Whin am

sketches of church ard stat

ir the inst eight 



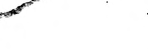


SKETCHES OF CHURCH AND STATE 


\section{SKETCHES OF}

\section{Nov ? 1914}

\section{CHURCH AND STATE}

IN THE

\section{FIRST EIGHT CENTURIES}

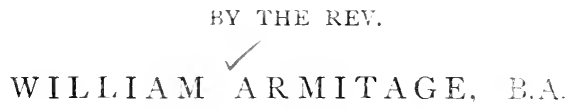

VICAR OF SCOTFORTH, LANCASTER:

LATE SCHOLAR OF EMMANUEL COLLFGE. CAMSRIDRE

RIVINGTONS

WATERLOO PLACE, LO.TDOA 


\section{$P R E F A C E$.}

THE facts of the following pages have been given on the authority of the Ecclesiastical Histories of Eusebius and the Venerable Bede; the Antiquities of Josephus; Gibbon's Decline and Fall of the Roman Empire; Hallam's Middle Ages; Maclear's History of Christian Missions ; Blunt's History of the Church of the First Three Centuries; Bishop Browne's Exposition of the Thirty-nine Artieles of Religion. The object in writing them has been to bring into a popular form some of the leading persons and events, parties and movements, in the Church and the world, during the first eight centuries of the Christian era; and where observations have been made or inferences drawn, it has been with a desire to keep within the sanction and authority of our own Church of England.

The records of the early Church should be known, that we may see and understand the 
historic position of our own Church, and her close affinity with the early Church in constitution, government, and doctrine. It is necessary that the early history of the Church of England should be circulated as freely and widely as possible, if she is to resist with success the assaults made upon her, and if she is to win the affectionate esteem and firm adherence of the masses, whose influence has now become prelominant for good or for evil. 


\section{CONTENTS.}

CHAT.

I. Extension of the Roman Empire into Britain, . . . . . . . . . 1

II. Early Struggetes of the Church with Jews AND GNostics, . . . . . . 10

III. Heresies and Persecutions, . . . 21

IV. Cheistian Apologists, . . . . . 31

V. Christianity Established bi the Stite, . 4’

VI. The Arian Heresy, . . . . . $\$ 2$

VII. Growing Power of Roman Bishops, . 6.3

VIII. GOTHIC INrasions, . . . . . . 75

IX. Growing Cormeptions in the Church, . 86

X. The Miraclei of Saints, . . . . . 96

XI. Northtmbilan Kings, . . . . . 107

XII. The Easter Contronerst, . . . $11 \%$ 
viii

Contents.

CHAP. PAGE

XIII. General Codncils, . . . . . . 128

XIV. Attila, King of the Huns, . . . 140

XV. Monastic Institutions, . . . . . 152

XVI. Mahomet, . . . . . . . . 162

XVII. Mahometan Conquests, . . . . 173

XVIII. IMAGe-Worship, . . . . . . 186

XIX. Irish Missionaries, . . . . . . 198

XX. Charlemagne, . . . . . . 211

Chronological Index, . . . . . . 223

INDEX, . . . . . . . . . . 229 


\section{CHAPTER I.}

EXTENSION OF THE ROMAN EMPIRE INTO BRITAIN.

"OUT of Zion shall go forth the law, and the Prophecy word of the Lord from Jerusalem." So spake filment. the Prophet Isaiah. Accordingly the Church of Christ was first established in Jerusalem, by the miraculous descent of the Holy Spirit upon the Apostles. From them shone forth the rays of Gospel light, which soon reached the shores of Britain. The cities and countries first visited were those nearest to the centre of light-Palestine, Egypt, Asia Minor, Greece, Italy, Gaul, Antioch, Ephesus, Athens, Alexandria, Rome. All these, notwithstanding their extent and distance from one another, were included within one grand Empire, and bound together by one elaborate system of government, of which the headquarters were at Rome, and chief was an Emperor entitled Augustus. 1 Within the Empire every facility was

1 "Augustus was therefore a personal, Cæsar a family distinction. The former should naturally have expired with 
CHAP. I. made for passing safely and rapidly from nation to nation, and from city to city ; first, for military purposes; and next, for the general convenience of subjects in all parts of the world. The words of the prophet were thereby literally fulfilled: the way of the Lord was prepared, and His paths made straight; the valleys were exalted, and the mountains and hills made low; the messengers of life and light were able to run freely into all lands, and their words unto the ends of the world.

Julius

Cæsar's first invasion of Britain.
The first spread of Christianity, within and beyond the limits of Palestine, coincides in point of time with the first serious attempt to conquer Britain; and it was the only conquest made by the Empire during the first century of the Christian era. Julius Cæsar had made an invasion fifty-five years before the Birth of Christ. The island had previously been visited by merchants for the sake of traffic; but Julius Cæsar was the first Roman general to meditate and plan the prince on whom it was bestowed; and however the latter was diffused by adoption and female alliance, Nero was the last prince who could allege any hereditary claim to the honours of the Julian line. But, at the time of his death, the practice of a century had inseparably connected these appellations with the imperial dignity, and they have been preserved by a long succession of emperors, Romans, Greeks, Franks, and Germans, from the fall of the Republic, to the present time."-Gibbon, vol. i. 
its conquest. He was led to this by the assist- CHAP. I. ance which Britons had given to his enemies in the Gallic war. He effected a landing with great difficulty. As he approached the southern shores, he saw the hills behind covered with fierce-looking warriors-foot, horse, and charioteers-and was at once challenged with showers of missiles. "Leap," cried a standard-bearer, "into the water ;" and the soldiers leapt from their boats, fought their way to the beach, and succeeded in beating back the enemy. But no further progress could be made. The season was far advanced. Cæsar therefore hastened back with all his troops.

$\mathrm{He}$ made a second invasion in the following second summer. This time no enemy appeared in invasion. summer. This time no enemy appeared in view. He reached some way into the interior. Then he began to be harassed by attacks from the thick woods. On the banks of the Thames a great battle was fought with Cassivellaunus, the leading chief of the Britons, and won by the Romans. The victory led to a surrender by the neighbouring tribes; but its effect was seriously counterbalanced by the damage done to the Roman boats by storms and high tides. The summer was again at an end, and Cæsar was only too glad to get his soldiers safely across the Channel, with his many captives and hostages from the principal tribes of the south of Britain. 
CHap. I. After this the Romans left the island unmolested unitil A.D. 43.

Meanwhile the first of the Cæsars was assassinated B.c. 44. Under Octavian, the second, who reigned until A.D. 14, Jesus Christ was born. It was a time of peace longer than had ever been known in the history of Rome. Under Tiberius, the third of the Cæsars, who reigned until A.D. 37, Jesus was crucified; His Church was established in Jerusalem, and it increased and spread over Palestine and Syria. Then came Caligula, who reigned four years, and made some preparations for the conquest of Britain; but Claudius, mentioned in the Acts of the Apostles, was the first to take adequate measures in A.D. 43. The Romans established their dominion as far as the wall of Antoninus, built across the island from the Firth of Forth to the Firth of Clyde.

Rapid

During the years that Britain was being Church. effectually added to the Empire, the Gospel was being vigorously preached by the Apostles. The Apostle Paul travelled through Syria, Asia Minor, Greece, and Italy, probably into Spain, and possibly into Britain. Persecution inflamed the zeal of the first Christians, and extended the field of their labour. "The blood of the Martyrs was the seed of the Church." One heathen writer says, "The Christians of the Roman capital were a very 
great multitude." Another speaks of them as cHAP. I. "crowds of deluded fanatics." Both writers speak from observation at the time of the martyrdom of the Apostles Peter and Paul. And Gibbon affirms that by the middle of the third century there was in Rome one Bishop, forty-six Presbyters, seven Deacons, seven Subdeacons, besides many other inferior officers, and not less than 50,000 believers. Such was the Church of the capital. The Churches of other citiesAntioch, Alexandria, Carthage, for example-embraced an equal proportion of the population. From all these centres the light shone upon the regions beyond, and shone to a distance in proportion to its intensity at these great centres. It is remarkable that the decline of the Empire dates from the dawn of the Christian Church and the conquest of Britain.

At the time of the conquest the Britons were Religion of divided into thirty or more tribes, often at war Britons. with one another. They gave themselves the most frightful appearance; bringing their hair down over their foreheads, staining their bodies with a blue dye, and clothing themselves in the skins of animals. Their life and social habits were of the lowest type, not much in advance of the animals they hunted, whose flesh and milk were their principal food. Their religion was that 
CHAP. I. of the Druids, who were priests, judges, magistrates, and lawgivers. Their religious rites were performed in some secret shade; sacrifices were offered, not uncommonly of human victims. The mysterious rites were communicated to chosen youths, who were placed under the most stringent oaths of secrecy, and visited with the most terrible penalties if the oath was broken. Young men of the best families were initiated at their own desire, or by the wish of their parents and guardians. Some knowledge of the sciences, particularly of astronomy, was cultivated. The Britons were entirely at the mercy of the Druids, who had absolute power of life and death, and were presided over by an elected chief, called the ArchDruid.

The Roman Empire a preparation of the way of the Lord.

The Roman conquest was the preparation of the way of the Lord into Britain. Thereby the country became settled and consolidated, life and property were rendered secure by a strong government, and there was freedom of intercourse with foreign nations, who had hitherto been jealously excluded. Towns were built, roads made, forts erected at longer intervals, posts established at shorter, and milestones set up. The posts were at distances of five miles, and provided with horses for the use of the Roman legions and of travellers. By the roads a journey might be 
made with comparative ease into any part of the CHAP. I. Empire. From Jerusalem, the centre of Christianity, to Rome, the centre of the Empire, and from Rome into the very heart of Scotland-the farthest limits of Roman dominion-a distance of over 4000 miles, the messengers of the good tidings might travel with tolerable security. The way was thus prepared for the ambassadors of Christ from Zion to the east, the west, the north, and the south.

After their conquest, Britons were drafted into The drafting the Roman army for service abroad, and troops of Roman were drafted from other nations into the legions which garrisoned the island. British soldiers soon obtained a reputation for valour, and found their way into the legions which guarded the capital, where the word of the Lord might be heard from the lips of Apostles. And on their return to their native land, they reported what they had heard of a Saviour for all men.

The number of soldiers required to maintain Roman the conquest, and to keep Britain in subjection, sometimes was three legions, - that is, about 30,000 men, very many of whom must have had some acquaintance with the new religion. A Christian writer of the second century says, "There was no nation of the Empire where the Gospel was not preached, and disciples made, and churches established." 
CHAP. I. Christian converts were constituted into

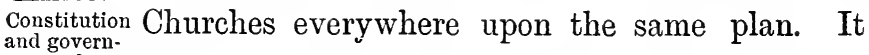
and governChurches.

was a maxim that there was no Church without a Bishop, who was intrusted with the government of the churches within the several districts and cities. Believers were everywhere knit together into one body by the bonds of a common faith and obedience, and marched under the banner of a common Lord, Jesus Christ, the Chief Shepherd and Bishop, from Whom sprang a succession of chief ministers in every Church, through the laying on of hands, with prayer for the Holy Ghost. To those thus Ordained, first by Christ, then by His Apostles, the charge was given to Ordain Elders in every city. The Ordination of Bishops, Priests, and Deacons is frequently referred to in the Acts and Epistles of the New Testament. Of such importance was the Episcopal government of the Church considered, that Eusebius, Bishop of Cæsarea, at the beginning of the fourth century, and the great historian of the early Church, has carefully recorded complete lists of Bishops of Jerusalem and other leading cities down to his own time. The Bishop of Jerusalem contemporary with himself was Hermon, who was the thirty-ninth in succession from James the Just, the Lord's brother.

After Claudius, the fifth of the Cæsars, came 
Nero, a monster of iniquity and cruelty, the chap. I. murderer of his mother, his wife, and his son, continuity and the bitter persecutor of Christians, under 吕 the whom St. Paul was beheaded, and St. Peter Episcopacy. srucified. But before their execution much had been done in the city of Rome, the scene of their martyrdom, in extending the Kingdom of their Master. It had been their earnest care to settle the infant Churches; and, wherever the Name of Jesus was received and believed in, to appoint overseers of the flock to take responsibility of feeding and folding them; and so they relieved themselves, before their departure, of the care of the Churches. For this purpose, Titus was left in Crete, Timothy in Ephesus, Mark in Alexandria, Linus in Rome, Dionysius in Corinth, and possibly Aristobulus, with his two companions, in Britain. 


\section{CHAP'TER II.}

EARLY STRUGGLES OF THE CHURCH WITH JEWS AND GNOSTICS.

Physical barriers removed.

Mingling of Christianity and Judaism.

The physical barriers to the spread of Christianity were removed by the Roman conquests. The Roman soldiers made roads, established and maintained garrisons, around which grew towns with a settled population; the wild tribes were held in subjection, and became amenable to law and order.

Jerusalem was the spring whence flowed the pure stream of heavenly truth into all parts of the world. The Gospel, which Jesus commanded to be preached to every creature, was first to be preached in Jerusalem. The leaven of Christianity, which was to influence the whole world, was first to influence the Jewish capital. But from the Gospel being first preached to Jews by Jews, Christianity and Judaism came to be considered, in the eyes of the Romans, one and the same; and for a hundred years Christians and Jews were regarded as one and the same people; 
Struggles of Church with Jews and Grostics. 11

were subjected to the same persecutions, which снар. II. were sometimes the result of Jewish sedition and revolt, and sometimes of the jealousy of the emperors, when they heard of Jesus of Nazareth, the King of the Jews, Who, as they feared, would supplant them.

It was necessary for the progress of the new Faith to make a separation, and to mark the distinction between Jews and Christians. The new wine could not be contained in the old bottles. The new cloth was not for the patching of an old garment. The Gospel was too vigorous and allembracing to be confined within the narrow limits of Palestine, and within the narrow prejudices of Judaism. Being in its nature expansive, it soon began to shake off an effete system, and to present itself in its own native beauty before all the nations.

For a little while the Apostles preached, as the vision of they had been commanded, only to their own Destruction nation-the Jews. Then came the vision of Peter, recorded in the Acts of the Apostles. A sheet was let down from Heaven, which contained all manner of living creatures, clean and unclean; then the command from Heaven, "Rise, Peter, kill and eat;" then the objection, "I have never eaten anything that is common or unclean;" then the reply, "What God hath cleansed that call not 
chap. II. thou common." This was Peter's commission from his Lord to welcome the Gentiles into the Church and fellowship of believers, and to minister to the Roman centurion, Cornelius, and his family, at Cæsarea. For so doing an outcry was raised against him, and the commotion within the Church was not easily allayed. But the great partition wall of Judaism was overstepped, although not yet broken down. Many of the believers still held that it was necessary for Christians to be circumcised, and to keep the law of Moses. To settle the controversy upon this matter, a Council was called in Jerusalem, under the presidency of James, the first Bishop, which decided against the necessity of circumcision for Gentile believers; and, with regard to ceremonial uncleanness, required only that they should avoid pollutions of idols, fornication, things strangled, and blood. The Apostle of the Gentiles, St. Paul, had fought hard for this freedom. Yet circumcision was held, by the greater part of Christians, to be necessary for all Jewish converts: and so there were Christians of the circumcision, and Christians of the uncircumcision. The first fifteen Bishops of the Church of Jerusalem were of the former. The Temple worship and the ceremonies of the law were observed by St. Paul himself. Peter and John went up to the Temple 
to pray at the stated hour. St. Paul was purified CHaP. II. in the Temple, after the expiration of his vow, in company with other Jews, who were not believers. The synagogues, which were places of Jewish worship, were everywhere open to, and used by, the messengers of Christ in all the principal cities of the world, where Jews had settled. All this led to a confusion between Jews and Christians. But circumstances arose which soon manifested the necessity for a complete separation. The Romans found great difficulty in keeping the Jews in order; there were frequent revolts, especially in Jerusalem, which led to the siege and destruction of that city by Titus, A.D. 70. The chosen people had filled up the measure of their iniquity. They had killed the Lord's prophets, and crucified His Anointed. They had persecuted His Church and its Ministers. Therefore, as Christ had predicted, their Temple and city were overthrown and utterly destroyed. Untold miseries were suffered by the besieged; the Roman army carried off and sold in the slave markets of Rome those who had escaped the siege and destruction of the city.

Meantime the Christians had found a refuge on Church of the other side of Jordan, at Pella. The Church of cision. the circumcision had now its centre at Pella, but was still undistinguished from that of the uncir- 
CHAP. II. cumcision. It looked with fondness to the site of the ancient Temple and worship, and returned to Jerusalem, as soon as it was safe. It still was zealous for the ancient rites. At the same time the unconverted Jews became more stubborn in their opposition to the Romans, until the Emperor Hadrian, who reigned from 117 to 138 , banished all Jews from Jerusalem, and forbade them to come near it under the severest penalty. The Church of the circumcision was swept out at the same time, and the place colonised by people of other nations. For the future the Christians of Jerusalem were Gentiles, and the name of the city was changed to Elia Capitolina, after the emperor's own name Ælius.

Separation of Jews and Christians.

From this time Jews and Christians were no longer considered one and the same people. The separation was now complete, and Christianity was free to pursue its course without compromise with Judaism. The law had gone forth from Jerusalem : her work for the present was done; her very name was lost, and Christians no longer cast their longing eyes towards her. The centre of Christianity was now removed, and the Church was upon the open sea, with her precious freight, bound for the most distant lands.

Simon

Magus.

There was another obstruction to the freedom of her course, and the fulness of her work. Vessels 
that sail over Eastern seas become encrusted CHAP. II. with a kind of shell-fish, which adheres firmly to their sides, greatly impeding their progress, and seriously damaging their timbers. In like manner, corrupt doctrines, commonly called heresies, began their mischief upon the ark of Christ's Church. These corruptions were the work of certain leading men and their followers. The opinions of the world, the doctrines of heathen philosophers, were joined to the pure Word of God. The first arch-heretic was Simon Magus, honoured by the Samaritans, and afterwards by the Romans, with divine honours, as being "the great power of God." At Rome an altar was discovered bearing the inscription "Simoni Deo." This man had joined himself to the body of believers, in the hope of getting the power of conferring miraculous gifts of the Holy Spirit, and thereby of increasing his fame as a sorcerer. Although St. Peter denounced him, saying, "Thou hast neither part nor lot in this matter," he persuaded many that true Christianity was not what the Apostles but what he himself taught. Others followed him, disfiguring and corrupting the truth.

These errors and corruptions went to painful Menander. extremes. A disciple of Simon Magus, named Menander, taught that he was himself the 
CHAP. II Saviour, that he had come from the invisible world, that believers in him would live for ever, that even Angels derived their power and immortality through him. Like Simon, he was a Samaritan, who, as he travelled from city to city, spread doubt and confusion in the minds of believers, and raised the prejudices of unbelievers against the One true and only Saviour.

cerinthus. Another man of great influence taught, about the same time, that Christ's Kingdom was earthly, and would begin, after the general resurrection, with feasting, which should last a thousand years. According to his teaching, Christianity allowed every indulgence to the flesh. His name was Cerinthus. Polycarp, the good bishop of Smyrna, having accidentally met him in the baths of the city, fled at the very sight of him, and bade others in the building do the same, lest some fearful catastrophe should overtake them.

Docetz. Another class of heretics taught that our Blessed Lord took not, at His Birth, a real substantial body, but only the appearance of a body; that therefore He was not truly crucified, dead, buried, and did not truly rise again ; that Simon, the Cyrenian, who bore the Cross after Jesus, was crucified in His stead. They were named Docetæ.

Other
heresies. The Ebionites taught that Jesus Christ was not the Son of the Father, was not conceived by 
the Holy Ghost, but was the natural son of CHAP. II. Joseph and Mary. The Manichæans taught that matter is essentially evil, and that the Maker of the world is not the Father of the Lord Jesus. The Valentinians asserted that Jesus possessed not all the fulness of the Godhead, but was only an emanation from that fulness, called Logos or the Word. These were some of the corruptions which fastened upon the pure doctrine; the vain conceits and foolish imaginations of men of depraved minds. Heresies prevailed in the Church from the destruction of Jerusalem until the reign of the Emperor Constantine, who took Christianity under the special protection of the State in A.D. 321, and made it the one religion of the empire. He proclaimed his design to have his subjects taught a pure Christianity, as it had proceeded from the lips of Jesus and His Apostles.

There was one form of heresy which became the prevalent in the first century, combining with Christianity the philosophy of Greece and Rome. This philosophy had in it much that was good and true, noble and elevating. It taught the immortality of the soul, yet not in harmony with pure Christianity. It inculcated the doctrine that the human soul has a past as well as a future eternity. This philosophy held that there are 
CHAP. Ir. two independent principles of good and evil, and two independent powers presiding over the two distinct realms in which these principles operate. But Christianity forbids us to believe that there is any other god but One, or any power, good or evil, independent of the One living and true God. The union of heathen philosophy and Christianity made the latter popular, at the expense of purity. This union was very generally accepted throughout the empire. The Christians who favoured this combination were named Gnostics, "men of knowledge." Many, who would have turned away from pure Christianity, or Christianity in alliance with Judaism, readily embraced it in union with philosophy. This was especially the case with the more refined sections of society.

The formation and value of the New Testament.

But it was too great a price to pay-to sacrifice purity for numbers. And so it was felt by all who drank of the water of life from the fountain; and they felt it a duty to the Church to call men from darkness and error into the true light. Where could the Church look to behold that light, when Jerusalem was now trodden underfoot, the Saviour gone into Heaven, and the inspired Apostles all departed this life? It was remembered that some of the Apostles and first disciples had left records of their Lord's Life and doctrine; 
and it was found that these very errors and cusp. II. heresies had all been answered by anticipation in those records. The Apostles had left those sacred writings that believers might learn from them "the truth as it is in Jesus." Therein all ranks and degrees might learn their duties; and all errors in doctrine might be corrected. Those writings began to be read in the assemblies of the Church every Lord's Day. Copies of them were multiplied. The several books that were the genuine production of inspired men-whether Apostles, like Peter and John and Paul, or of an inferior order, like Mark and Luke-were collected into one volume, and called the New Testament, that it might be a canon rule or standard of faith and duty for the whole Church until the Lord's return. Copies were distributed among the churches; and some of these early copies exist to this day. There is one of the most ancient manuscripts of the New Testament in the British Museum; another in the Library of St. Petersburg; another in the Vatican Library at Rome. Some of these copies contain all the books of the New Testament; others only part; and others but fragments, of which some are very small. They are all exceedingly interesting and valuable, from their variety of material aud type, and from their harmony of teaching. 
CHAP. II. It was to this volume that the Church appealed

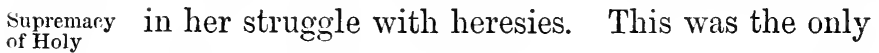
Scripture. antidote of error. Men might come and go; but the book remained to bear the same witness from age to age, and from land to land. It is a leading principle in the Church of England, that " the Scriptures of the Old and New Testament contain all things necessary to salvation; so that whatsoever is not read therein, nor may be proved thereby, is not to be required of any man, that it should be believed, as an article of the faith, or be thought requisite or necessary to salvation." And now, wherever the messengers of Christ go forth, they take with them this sure Word of God, and from it they deliver their message, as a corrective of all that is false and wicked, and as a standard of all that is good and true. If any one country or people has risen to a higher condition of general happiness and content, and to a firmer and more established power and dominion than others, it will be found to be due, mainly, to the influence, to the full and free use of the Old and New Testament by the Church, by the family, and by the individual Christian. 


\section{CHAPTER III.}

\section{HERESIES AND PERSECUTIONS.}

HeResy is an error in doctrine made to pass for truth. In the present state of our existence the the talse evil is ever mingled with the good, and truth is Jewsitsopen, never wholly free from corruption. But the enemies. heretics of the early Church went beyond mere inadvertence and natural infirmity, and maintained doctrines which by the Church had been distinctly condemned. It might be said that the Gospel itself, at its first preaching, was condemned by the authorities of the Jewish Church; and the infant Church of Christ was counted by the Jewish Church a body of heretics. But it may be replied that the Gospel was rejected altogether by the Jews in all its distinguishing features; whereas the heretics accepted it, adding thereto their own peculiar tenets, and their own peculiar colouring to what was true. The Jews were open and declared enemies of Christianity. The heretics were its false friends.

One form of heresy was specially associated 
CHAP. III. with Britain. The author was a Briton, named Pelagius. Morgan, who took the Roman name of Pelagius, residing in a monastery at Rome. It spread rapidly over great part of the Church. With Pelagius was associated Celestius, a native of Ireland. Britain was infected by this spiritual plague about A.D. 410, the year in which Rome was sacked by the barbarous tribes of the north. This invasion from northern Europe caused the complete withdrawal of the Roman armies from Britain, which had been under Roman dominion over three hundred years. It was now a prey to the Picts and Scots from the north of Scotland, whom the Romans had never been able to subdue. Thus the island was torn to pieces politically and religiously.

The Pelagian Pelagius, against whose teaching the Ninth heresy. Article of the Church is directed, taught that Adam was created mortal; that the sins of mankind spring not from his disobedience, but from each man's own act and will; that infants are born into the world as sinless as Adam at his creation; that we may do good and avoid evil, if we will, without the assistance of God's grace and Holy Spirit.

St. Augus- This heresy is the more remarkable from the
tine. great champion of the truth whom it called forth, the great Christian divine and luminary of the 
early Church, converted from heathenism by a cHAP. III. mother's prayers,-Saint Augustine, Bishop of Hippo, near ancient Carthage. He offered the most determined and successful opposition. He secured the peace of the Church and the condemnation of Pelagius by the decrees of the General Council of Ephesus, A.D. 431. His errors were combated in Britain by two learned Bishops from Gaul, named Germanus and Lupus, assisted by David, the great father of the British Church, afterwards known as St. David. The chief weapon used by the friends of truth was the Word of truth, the oracles of inspiration, the sword of the Spirit, which the Saviour Himself used in His conflicts with the arch-deceiver, answering each attempt to mislead with the words "It is written."

There was yet another obstacle to the progress The supreof Christianity and the establishment of Christian Maryist of churches. It should be remembered that the His Word. heathen have a religion to which they generally cling with passionate fondness. The worship of Diana prevailed in Ephesus, and in all Asia Minor. The end of the religion of Christ is to overcome and take the place of every other religion, as being the only religion which is true. Jesus says, "I am the way, the truth, and the life." Christianity seeks to rule in every heart, over every motive, and to rule alone. It was the policy of the 
CHap. III. Roman emperors, as long as they were heathen, to patronise and protect all religions, true or false, of the subject nations. Hence there was the great temple of all the gods at Rome, called the Pantheon, afterwards converted into a Christian church. Thus they sought to conciliate the nations they had conquered, and to compensate them in some measure for their loss of independence. But they forbade interference with one another's creeds. There must be no collision between one religion and another. This, however, was opposed to one of the first principles of the Gospel, which aims at the conversion of all nations, and is a message of peace, and a deliverance from all bondage and superstition into the glorious liberty of the children of God. The Emperors themselves had conquered nation after nation, but allowed no other conquerors, no other ruler-not even the King of kings. The Roman empire benefited politically the pagan nations, but the religion of Jesus blessed the inner life, as well as the outer, of all who most needed to be blessed. "In Him all the families of the earth are blessed." The perse- Christianity, therefore, by its principles and
cuting emperors. aims, must interfere with all other creeds, with all other religions, however ancient, however much venerated, and with the lives of all, both rulers and people, bond and free, learned and 
unlearned. A teacher of Christianity came to be chap. III looked upon as one who turned the world upside down; Christians, as a pernicious sect, to be punished, persecuted, destroyed. The emperors Nero, Domitian, Aurelius, Severus, Decius, and Diocletian are pre-eminent for their persecution. Aurelius was one of the most enlightened philosophers, and yet under him there was the most intense hatred of Christianity.

Lyons and Vienne, in the south of Gaul, Persecution were scenes of martyrdom, attended with every and Vieune. form of cruelty. The Churches of those cities sent to the Churches of Asia Minor the story of their sufferings. One of the martyrs was the aged Bishop of Lyons, another was Blandina, another a boy fifteen years old. The Bishop was old and feeble in body, but strong in faith, and looking with cheerful hope to receive the crown of Martyrdom. He was led by the soldiers before the chief magistrate, and after examination he was committed to prison. When the question was put to him, "Who is the God of the Christians?" he replied fearlessly, "Thou shalt know, if thou art worthy." On his way to prison blows and insults were heaped upon him by the rude multitude, while those at a distance cast stones at him, the magistrates urging them on. Nothing was omitted in the way of injury and reproach. 
CHAP. III. The pagan crowds thought they were thus avenging their gods. After two days in prison the old man expired at the age of ninety. Sufferings of Blandina received even worse treatment. Not-
Blandina. withstanding her sex, she was thrown to the wild beasts, to be torn in pieces for the amusement of the populace, for whom such scenes were provided on special occasions. She was raised up, tied to a stake that the attacks of the hungry beasts might be the better seen. Her faith was firm, and did much to strengthen the faith of her fellow-Christians. It was the hope of her enemies that she would deny the Faith. By a singular providence the wild beasts did not molest her. Then she was carried back to prison, and reserved for other conflicts, other victories, and a brighter crown. It was the common confession of the Martyrs, when they were asked their name, city, and nation, to answer, "I am a Christian, and among us there is no wrong."

Further sufferings of Blandina.
During Blandina's imprisonment, many of her fellow-citizens were put to death. Last of all, she herself was brought out again, together with the boy of fifteen, who was commanded to worship the heathen idols. He refused, and was immediately despatched. Blandina, who had already been thrown to the beasts, was now scourged, fastened to a heated iron chair and thrown into 
a pit with a furious bull. But her thoughts were CHAP. III. upon her Heavenly Friend, and upon the crown of righteousness that awaited her. She was delivered from all fear and sense of pain, and in death proved herself more than conqueror, through Him that loved her. The heathen themselves confessed they had witnessed no such sufferings as those which the holy Blandina endured.

At the sufferings and death of the Martyrs the The boast of heathen would laugh and dance, boasting that the heathen. they had put the Christians to shame, and saying, "Where is their God? What good is their religion, which they prefer to their life?" They refused their bodies a burial; they gathered them into a heap and burnt them, then cast the ashes into the river Rhone, that so they might conquer the gods of the Christians, and take away all hope of their resurrection. "Now," said they, "we shall see whether they will rise again, and whether their God will deliver them out of our hands."

The acknowledged purpose of persecution was Failure of to deter the heathen from embracing so exclusive a religion as Christianity, and to drive back as many converts as possible to their old superstition and idolatry. Every imaginable cruelty was devised and practised, but in vain. The enemy 
CHap. III. was bound to admit himself beaten. Christianity triumphed, believers multiplied in numbers, and increased in every Christian grace and virtue. It is true some were deterred, but many were faithful unto death, and did more by their death to extend and deepen the influence of the Church than thousands of professors who, by their lukewarmness, escaped with their lives. Persecution made every true disciple of Jesus look up to his Master for strength and victory in the trial. And such was their joy in the prospect of death, in the midst of their conflicts, that suffering and martyrdom had no terrors. They were even desired and welcomed, because of the immediate passage which was obtained thereby to the mansions of the blest, and the crown of glory.

The benefits of persecu-

Although the persecutions of the first three centuries were great obstacles to visible progress, they served much to deepen and confirm the Christian life and character. Evil was overruled for good. Many who denied the Faith, when they were called upon to make that denial public, repented, and made instead a public confession of it. Some were suddenly struck with thoughts of the pains of Hell as they witnessed the pains of persecution. Others were so deeply impressed by the fortitude and courage of the Martyrs that 
they readily followed their example, that they cusp. III. might share their glory.

Under the persecution of Diocletian, A.D. 305, $\underset{\text { dom of }}{\text { The martyr- }}$ died the British Martyr St. Alban, near the town St. Alban. which bears his name. Whilst in his heathen darkness, a persecuted Christian flew to him for refuge. For a time Alban observed his earnest devotion and prayers night and day; he listened attentively to his instruction in the knowledge of Christ. He became a Christian; and when it was reported that Alban had sheltered a Christian, a strict search of his house was made by order of the governor. When the soldiers arrived, Alban appeared instead of his guest. In the dress of the refugee, he was taken into the presence of the governor. On examination he was soon discovered. The governor's anger grew fiercer; he threatened Alban with all the punishment which he had designed for him whom he had sheltered, unless he returned at once to his old faith. When he was asked his name he answered-" By my parents I am called Alban; but I am a Christian, and I mean to adore and worship the living and true God for ever." Upon this he was tortured, and hurried away to be beheaded. On his way to the place of execution, near the river Colne, which flows through the cuwn of St. Albaus, he was accom- 
CHAP. III. panied by a large and sympathetic crowd. The officer charged with his execution beheld his holy fervour; and, being won over with admiration, he threw down his drawn sword, and begged that he, too, might suffer as a Christian, and share his reward. The other executioners and the crowds, in amazement, followed on to the neighbouring hill, chosen by Alban himself as the place of his execution. There the holy man was beheaded, and with him the officer, into whose charge he had been delivered. Such was the impression produced by their noble behaviour, that the governor could not refrain from expressing his admiration, and ordered that the persecution of Christians should forthwith cease. Thus, instead of being diminished and destroyed by persecution, the Church of Christ increased every day more and more, gained a firmer and wider hold upon the nations of the world, and multiplied and prospered throughout the Empire. 


\section{CHAPTER IV.}

\section{CHRISTIAN APOLOGISTS.}

In times of persecution there was no alternative Christians but to suffer or deny the Faith, or appeal to the undernorstile Emperor, with the chance of obtaining some degree of relief. For some time Christians were necessarily a minority in every city and country, often outside the protection of the State, and at the mercy of an unrestrained pagan multitude. In some instances Emperors were of a just and kindly disposition. But if the Emperor were even favourable to Christians, the distant parts of a large and unwieldy empire were little affected by his personal feelings, and especially when the local governor was a man of an entirely opposite disposition and character, and of views which were hostile to the Church and faith of Christ. Under such a governor, what could a few despised Christians do but suffer or adopt the favourite superstitions? But even a denial of the Faith was not always found to bring safety and 
CHAP. Iv. deliverance; and many, knowing this, were the more bold to endure to the end.

Apologies to the Emperors.

Sometimes there was hope in an appeal to the Emperor, in addressing to him what has been called an "Apology." This was a defence of Christianity, demonstrating the beneficence of its principles and action, and was usually drawn up by the most learned and pious of the Christians. The most famous of the early Apologists were Justin Martyr and Tertullian-the one a Martyr, under the persecution of Marcus Aurelius; the other a Presbyter of North Africa, in the reign of Severus. Justin Martyr wrote two Apologies of considerable length, which abound in references to Holy Scripture. His first was addressed to Antoninus Pius, a humane Prince, who vouchsafed a favourable response. The second was addressed to his son Aurelius, refined and very learned, but strict and intolerant; and no immediate good resulted.

The arguSome of the arguments of these Christian ments of the
Apologists. Apologies may be given. Justin reminds the Emperor and people of Rome that heretics, while calling themselves Christians, were only corrupters of Christianity; and yet they were allowed to live unmolested; they were even honoured in Rome itself with divine honours. He refers to a man whose name was Antinous, 
originally a slave of Hadrian, who was honoured CHAP IV. by the Senate of Rome, as if he were a god, by the institution of a festival and the erection of a city to him. How different was the lot of Christians! How truly did their condition correspond with the words of their Lord, "The world loves its own, but Me and Mine it hates"!

There was a sedition amongst the Jews in the The reign of Hadrian, led by one Bar-Cochebas, for of Hadrian which Christians alone were made to suffer dreadful torments. And they had no escape, except by denying their Master and speaking blasphemy. Justin Martyr refers to his own history. He had lately been converted from Greek philosophy to Christianity; he had heard Christians slandered; he was impressed by their patient endurance of suffering and shame for Christ's sake; he had seen them suffer and die, and he concluded they could not be bad. "For," he asks, "what lovers of this world and its pleasures would die so cheerfully, that they might be deprived of their pleasures?" Hadrian, the Emperor, had received from a certain Asiatic Governor letters, which complained that the Christians were pursued by the violence and howling of a mob, and put to death without a trial. The Emperor commanded that charges against the Christians should be substantiated, 
CHAP. Iv. and an opportunity allowed for their reply in open court. His words are: "If any man bring a charge against the Christians of breaking the laws, let him prove it; and then, if guilty, let him be punished in proportion to the offence. But, if he fail to do this, let the accuser be punished for his false accusation."

The favourable decree

This conduct of Hadrian, Justin commends to of Antoninus Pius. the attention of the Emperor Antoninus as an example worthy to be followed. He speaks of Christians being of every race within the empire, unjustly hated and slandered, of whom he is not afraid or ashamed to count himself one. He entreats, with all earnestness and humility, that the Emperor would, by a royal edict, grant them protection from the insults and violence with which they were treated, especially by the country people. To this appeal Antoninus returned a favourable and gracious answer. $\mathrm{He}$ pointed out to the people of Asia, in a royal decree, that the Christians were very diligent in the worship of their God-yea, more diligent than themselves in the worship of their gods; that they were proved not to be atheists, as they were accused, by their suffering death sooner than deny their God. "And in regard to the earthquakes, of which you consider their impiety and neglect of the gods to be the cause, they are zealous, while 
you are careless; they are earnest, while you are chap. Iv. indifferent; they worship their God, while you persecute them for so doing, even unto death." Antoninus then referred to letters written by governors of provinces to his father, Hadrian, and to himself: "To those governors I returned the answer that I adhere to the counsel given by my illustrious father-namely, that no charge shall be brought against Christians except in open court, and there proved."

Justin Martyr was afterwards accused himself Justin under Aurelins, the on of Antoninus, and con- Martyr's under Aurelius, the son of Antoninus, and con- defence of demned to death, from which he has been entitled himself. "the Martyr." His accuser was a philosopher of the Cynic school, named Crisces. It was the ordinary charge of atheism and impiety that was brought against him, and to please the enemies of Christianity among the higher ranks of society. Justin boldly challenged his adversary to a public disputation, which Crisces prudently declined. The timid and dainty philosopher was no match for the courageous and well-instructed champion of Christians.

To show how one Christian often brought Christians another into danger, through the whole body comperimes being knit together by the self-sacrificing bond friends. of love, Justin, in his Apology, tells the following story:-A certain man and his wife had led im- 
CHAP. Iv. moral lives. The woman became a Christian, and then laboured for the conversion of her husband. She pressed upon him the truths of Christianity, and especially the punishment of eternal fire, which shall consume the ungodly. Still he followed his evil courses, and, moreover, took another wife. She then sought a separation. which made him proceed still further in his ungodliness. She then allowed the question of separation to rest for a time, in the hope of still effecting his conversion; but in vain. She then obtained her divorce; and he retaliated, seeking to accomplish her ruin by publicly charging her with being a Christian. In this he failed, and immediately after proceeded to persecute another person, whom she had been the means of bringing over to the Christian faith. This person was imprisoned by the order of the Governor. Another Christian remonstrated, and asked why one who had lived a good life, and whose only offence was that he bore the name of Christian, should be punished. Such a course was unbecoming, and unworthy of the Emperor, the Senate, and people of Rome. The Governor merely replied, "I am not such a one as thou." "Certainly," said the Christian; and he, too, was sent to prison.

Another Apologist of great fame was Tertullian, well skilled in Roman law. In his Apology he 
refers to an ancient decree, that no god should cHAp. Iv. be admitted by the Emperor until first approved Tertullian's by the Senate. He mentions an instance where Tiberius, this this decree was applied, and then passes on to its application to Christianity, which attributes a Divine nature to the Lord Jesus Christ. He says that Tiberius referred the Godhead of Jesus to the Senate, with an assurance that he was himself satisfied that Jesus was the Son of God. But the Senate disapproved. The Emperor, notwithstanding, maintained his opinion, and threatened with death all false accusers of Christianity. Tertullian refers to Nero, the first of the persecuting Emperors, and says, "Any one who knew Nero, knew that no one was condemned by him except for some great and good deed." To the Emperor Domitian he makes allusion, as being the next great enemy of the Church. Although at first he was as cruel as Nero, yet upon better acquaintance with Christianity he relented, and recalled those whom he had banished, restored their goods and property, of which they had been unjustly deprived - at which time the Apostle John returned from his banishment in the Isle of Patmos.

Tertullian uses another argument, which he The conduct addressed to the Senate. He refers to letters of Murelins. written to the Senate by the Emperor Aurelius, 
criap. Iv. in which he relates the distress of the army in Germany from want of water during a terrible drought, when they were saved by the prayers of the Christians of the army; and thereupon he determined to punish with death any man that brought a false accusation against them. Tertullian proceeds to ask- "What kind of laws can those be whereby ungodly, unjust, and cruel men are allowed to persecute us and us only?-laws which Vespasian would not put into operation against the Jews after his victory over them, which Trajan partly set aside when he forbade Christians to be sought after for punishment?"

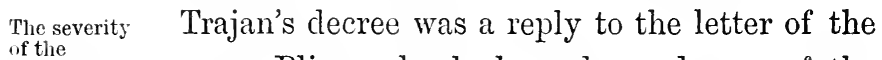
Roman law towards younger Pliny, who had condemned some of the Christians. Christians, but became perplexed when he discovered how numerous they were. He wrote to the Emperor, saying that he could not consider those as criminals whose only fault was that they were unwilling to worship idols. "And this is what they do: they rise early and sing praises to Christ as their God; and in their life they are careful to avoid murder, fornication, covetousness, and such-like." Tertullian asks again-"What kind of laws are these against Christians which favour the ungodly, which neither Hadrian, who was most diligent in all departments of government, nor Antoninus regarded ?" He indignantly 
breaks out in the following words:- "We spring cHAP. Iv. up and increase in numbers in proportion as you cut us down. The blood of the Christians is the seed of the Christians. Many amongst yourselves exhort to patience under pain and death; yet they do not win half as many converts by words as the Christians who teach by deeds. This very obstinacy of the Christians which you denounce is itself a teacher. For who can contemplate it, and not be moved to inquire, 'What there is in this matter at bottom ?' Who can inquire, and not be drawn towards it? Who be drawn towards it, and not himself feel a desire to suffer?" Thus Tertullian, by way of apology and defence of the Christians, sets forth the sufferings and patience of the Christians and the injustice of the laws, which the best of the Emperors treated as a dead letter.

By these Apologies of Justin Martyr, Tertul- Good effect lian, and others, the Emperors and the higher Apologies. classes of the empire were leavened with the doctrine of Christ, and were either drawn into the net of the Gospel, or led to regard it with more favour.

The pen of the learned was also employed with The writings

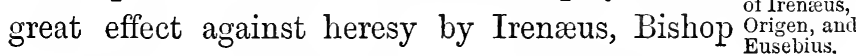
of Lyons, a contemporary of Tertullian; by Origen, the great commentator on Holy Scrip- 
CHAP. Iv. ture; and by Eusebius, the great historian of the early Church. To these and other early writers the Church of all future ages has been greatly indebted for the defence and preservation of pure doctrine and sound principles of Church Government. The History of Eusebius is full of the most interesting facts connected with the rise and growth of the Christian Church during the first three centuries; the hindrances to that growth; the conquests of Christianity over physical difficulties, over imperial power, over national depravity, over the foul insinuations and secret mischief of error and false doctrine, over violence and injustice. These victories were obtained by a people comparatively few in number, poor in regard to worldly means, despised by the rich and the noble in society, and unprotected by the laws. The laws, which should have afforded impartial security to all classes, ranks, and degrees, were specially severe against Christians, and aimed at the extinction of Christianity.

The History Eusebius has preserved copies of letters from
of Eusebius. Church to Church; from Emperors to the Governors of provinces, and from Governors to Emperors; decrees of the Senate; extracts from the leading Christian writers who preceded him; quotations from nearly all the books of Holy Scripture, and 
from the Antiquities and the Jewish Wars of cHap. Iv. Josephus. He has traced the progress of the sacred Scriptures to their final settlement in one volume of the Old and New Testament. He has continued the history of the Church from the New Testament times until his own, and has supplied many facts additional to what have been supplied by the New Testament during the period that it was being written. The progress of the Churches in various parts of the world has been traced; their modes of worship; their peculiar trials ; the succession of their Bishops ; their position relative to other Churches; their agreement and union in doctrine and government. He has also described the life of Christians, and the steps whereby converts were introduced into full communion. 


\section{CHAPTER V.}

CHRISTIANITY ESTABLISHED BY THE STATE.

Union of

Church and

State.

At the end of the third century and the beginning of the fourth, a great and important change took place in the relation of the Church to the State. Hitherto, the Church had at the best received a bare toleration; and many times it had been bitterly persecuted by the State. The Church, notwithstanding, grew and increased both in numbers and influence; at the same time Paganism declined. In the year 324 the religion of Jesus Christ was not merely a rival-it had become supreme. The Emperor Constantine not only effected the separation of the State from Paganism, but completed its union with the Church of Christ-a union which has continued to this day in many lands.

Division of the Empire.

The following circumstances led to this result. Diocletian was Emperor from A.D. 285 to 305. Born a slave, he reached, by his military skill and prowess, and by a subtle policy, the highest pinnacle of an empire which extended from 
Britain to Persia, and from the forests of chap. v. Germany to the deserts of Africa. It was a dominion too wide to be held within the grasp of one man. Diocletian adopted the principle of multiplying the Emperors to four; two of them to be named Augustus, and two Cæsar; the latter being of inferior rank. Diocletian was the chief Augustus, and Maximian the second. One Crsar was assigned to each Augustus; Constantius to Maximian, and Galerius to Diocletian. Maximian governed Italy, and Diocletian the Last; the northern and western provinces fell to the Cæsars. Constantius, who was the father of Constantine the Great, ruled in Britain, and har his palace at York, where he died.

The Emperors of the West were favourable Diocletian to Christianity, while those of the East were hostile. Under Diocletian, the fiercest persecution raged in the East; and its effects were felt, as the death of St. Alban bears witness, in the far West. It continued for ten years, and was principally instigated by Galerius, the Cæsar; although named after Diocletian, the Augustus; and it fell with most severity upon Upper and Lower Egypt, Syria, Asia Minor, and Palestine. Great numbers were put to death, with every form of torture; churches were demolished, and their property confiscated; the Holy Scriptures were 
CHaP. v. collected and burnt; all Divine ordinances and assemblies for worship were forbidden. Some of the Christians fled for refuge to mountains, deserts, and caves. Many were required to give up their religious books, and upon refusal were instantly put to death. Others, less courageous, yielded in presence of death, and received the name of Traditores-givers up of the Holy Scriptures. Others, who were required to offer incense to the heathen gods, refused, and were put to death. Others, to save their lives, complied; and were named Thurificati-the offerers of incense.

Constantius Constantius, the Cæsar of the West, who was and Helena. distinguished by mildness and benevolence towards all his subjects, was favourable to the Christians. The celebrated Helena was his wife, and the mother of Constantine. Upon his elevation to be Cæsar, he was required by his Augustus, Maximian, to put away Helena, and marry his own daughter.

Carausius makes him-

The entry of Constantius into Britain gave self Emperor some remarkable indications of her future power
of Britain. and position in the world. The Romans had built a fleet, to put a stop to the incursions from the Continent into the island; and they put this fleet under an able and skilful commander named Carausius. This man decided to make himself master both of the fleet and the isiand. $\mathrm{He}$ 
sailed from Boulogne, drew to his side the Roman crap. v. troops in Britain, separated Britain from the empire, and proclaimed himself its Emperor. His rnle lasted from A.D. 287 to 294 ; when Carausius was assassinated. Constantius, who was popular with the army on the Continent, and likewise with the troops in Britain, on the death of Carausius, seized the opportunity to re-establish Roman authority in the island. In this he was successful. The remaining years of his life were spent in beating back the tribes of Picts and Scots, and in settling the affairs of the island.

After a reign of twenty years, the two Emperors Constantine Augustus, Maximian and Diocletian, abdicated by Emperor. mutual agreement; the two Crsars now became Augustus; and new Cæsars were appointed by Galerius-Maximinus for the East, and Severus for the West. And, in addition to these, Maxentius, the son of Maximian, established himself as Cæsar in Italy and in Rome. Thus there were at this time seven living, and five reigning Emperors. It was then that Constantius died at York, in July 306. His son Constantine, who had been in the army of Diocletian, was summoned to the bedside of his father; and, after his death, immediately-and without any reference to his father's colleagues-proclaimed himself 
CHAP. v. Emperor Augustus. Galerius vigorously opposed this proceeding; but the popularity of Constantine with the army, his numerous military successes, his noble bearing, his energy and boldness on all occasions, established his position. The seven Emperors were soon at war with each other, and they were gradually reduced, until Constantine closed a series of brilliant victories by the overthrow of the only remaining colleague, the Emperor Licinius, on the plain of Adrianople; and by the siege and capture of Byzantium, on whose ruins he built the new city, named after himself, Constantinople. But the most important consideration connected with the triumphs of Constantine, was that, like his father Constantius, he favoured Christianity; and made it the one religion of the empire, as he was now the sole Emperor.

Diminished authority of the Senate.
There was an authority in the State, sometimes not inferior to that of the Emperor-the Senate of Rome, which met regularly in that city. One half of the empire was under the government of proconsuls appointed directly by the Senate; the other half under proconsuls appointed by the Emperor. To limit, and ultimately to destroy, the authority of the Senate, the Emperors were multiplied. And when they were reduced to one, Constantine aimed, like his predecessors, at 
the same object, by taking up his abode, not in СнA $\mathrm{v}$. Rome, but in other great cities-York, Milan Nicomedia, Antioch, Constantinople; and by choosing the new city of Constantinople as the centre of government, instead of Rome.

The remarkable position now occupied by Con- Constanstantine, worthily named the Great, had been tine's $\begin{gathered}\text { victories and } \\ \text { conversion. }\end{gathered}$ obtained by a continuous succession of victories, in battles which had been forced upon him by his colleagues. They hated him for his Christianity, and envied his successes. They plotted against his life, but he was preserved through all dangers by the singular Providence of God. He, who had now no earthly rival, no other sovereign with whom to share his wide dominion, laid all his glory at the foot of the Cross, and confessed himself the humble and unworthy servant and subject of Jesus of Nazareth, "the King of Kings and Lord of Lords."

Notwithstanding their flight, their sufferings, Great their death, their degradation from office in the rever the $\begin{gathered}\text { ove } \\ \text { ending of }\end{gathered}$ Imperial service during the Diocletian Persecu- perseention, tion, the Christians still were numerous in the ef chtrishCourt, the army, the Senate, and among the chiefs of the State. It was the distinguishing policy of Constantine and his father to protect them, and promote them to the highest offices in their service. They had the wisdom to observe their 
CHAP. v. superior merit, and those qualities which make a government and an empire strong. There was now a period of repose and of worldly prosperity for the Church not altogether favourable to the progress of true Christianity. It was universally admitted by the Church herself that the recent persecution had been a Divine chastisement for evils and abuses, which had multiplied and grown to a great height during a previous time of ease and prosperity, when luxury, pride, strife, and divisions had grievously prevailed in the Church. The fire of persecution came to restore unity and purity, and the beauty of holiness. Now that the trouble was over, and the refining process ended for the present, the Christians united heart and voice, saying: " $\mathrm{O}$ sing unto the Lord a new song, for He hath done marvellous things. With His own right hand, and with His holy arm hath $\mathrm{He}$ gotten Himself the victory. The Lord declared His salvation; His righteousness hath He openly showed in the sight of the heathen." They acknowledged, at the same time, that those whom trouble and persecution had removed from the earth were in possession of the better inheritance in Heaven. But the portion of those who were still left behind afforded clear proofs of the Divine goodness and mercy; and again songs of praise would burst from their lips, in the words 
of the Psalmist: " $\mathrm{O}$ come, see the works of the cHap. v. Lord, what goodness He hath wrought upon the earth. He maketh wars to cease in all the world; He breaketh the bow and knappeth the spear in sunder." And again: "I saw the ungodly in great prosperity, and sexalted like the cedars in Lebanon. I passed by, and lo! he was not. I sought his place, and he was nowhere to be found." Now the day was bright, without a shadow. The glory of Christ illumined the Church throughout the world. Now began the rebuilding of churches which had been destroyed, in the midst of universal rejoicing. Constantine issued a decree for this purpose, and granted assistance in the work from the Imperial revenues. They rose in nobler proportions, and in more beauty and grandeur than before, and were more worthy of the bountiful Giver of all. The houses of God were also frequented without fear in city, town, and country. The Lord's Day and other Christian Festivals were everywhere observed. Bishops were summoned by the Emperor to the great Council of Nicæa from all parts of the empire, and by their united voice they issued the Nicene Creed.

Thus unity and harmony prevailed through Harmony

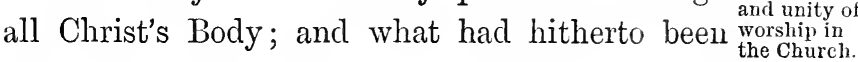
spoken in secret was now proclaimed upon the 
chap. v. housetops. There was one spirit of Divine grace; one life from our Lord Jesus Christ; one eager faith; one hymn of praise from every mouth and. every heart. Christian worship was free and unmolested. The ministrations of the Clergy were regular and uninterrupted. The Word and Sacraments drew together the whole body of believers, and fresh converts were gathered in daily.

Rome

delivered from Maxentius.

One event will give some clue to the mind and character of Constantine in regard to Christianity. He had been brought up and educated in the superstitions and practices of the heathen. In birth, education, and kindliness of disposition he surpassed his colleagues; and while he extended his power, he ever sought the happiness and welfare of all the nations under his sway. His conquest of Italy was the result of his determination to free her from the tyranny of Maxentius, the Cæsar. With this determination, he swooped down like an eagle from the North, across the Alps, into the plain of Lombardy. $\mathrm{He}$ gained a decisive victory over the generals of Maxentius, and marched straight upon Rome, without losing a single day. Before entering on the expedition, he offered up prayers to the Saviour to be with him as his leader and guide, whilst he restored a people to the freedom of 
their ancestors. The Christians of the time com- снар. v. pared the defeat of Maxentius to the destruction of Pharaoh and his army in the Red Sea. The waters of the Tiber swept away many as they His victory

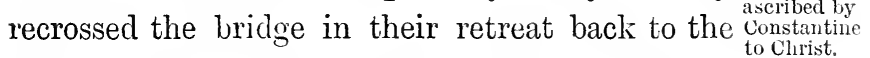
city; and the victors sang the Song of Moses. The rescued citizens gave a joyful welcome to their deliverer and benefactor; but he took not the praise and glory to himself. He raised, as a trophy, a statue of himself in the most populous part of the city of Rome; and in the right hand of the statue he placed the figure of the Cross, and inscribed thereon a declaration of his faith in the Lord Jesus, as the author of all his success- "By this have I delivered your city from the yoke of the tyrant, and made free once again your Senate and people." 


\section{CHAPTER VI.}

THE ARIAN HERESY.

Evils flowing THE establishment of Christianity by Constan-
from prosperity. tine as the religion of the Empire was not an unmixed good. The evil of man's nature is not to be subdned by an imperial decree. Christian Emperors and Princes, Christian Bishops and other ministers of the Church, were often a long way from what they ought to be in their life and character. Before its establishment, the evils in the Church had been kept in check by the circumstances of a lower station. By the circumstances of a higher station, their growth and development were manifested in a painful degree. It is an old story, and the common experience of individual persons, as well as of States and Churches. The Church in her prosperity became an enemy to herself. She became divided against herself; and her worst foes were those of her own household. Pride, ambition, worldliness, grievous heresies, and scandalous lives, became painfully common. 
The happiness of mankind depends upon an caAp. vi. alliance of the rulers of Church and State with The truth. Although converts to Christianity, Con- not alvays stantine and his sons were not always on the side ${ }^{\text {of truth. }}$ of truth. They were frequently changing sides, according as they were influenced, first by one party in the Church, then by another. Policy was thought to demand the patronage now of one set of doctrines, and now of another. The Church was divided into Catholics and Heretics, who wrangled for years and years upon the most solemn mysteries of the Divine Nature-the existence of the Trinity; the Three Persons of the Father, the Son, and the Holy Ghost in One God.

By the year 324 Constantine had reduced the The Edict whole Roman Empire under his sole dominion, from Britain to Ethiopia, and from Spain to India; and had established over this wide area the religion of Jesus Christ. Yet Christians of all sections were in a minority, and divided amongst themselves. The Emperor tried a policy of equal toleration. In the year 313 he issued the famous Edict of Milan, giving Heathen and Christians alike the privilege of worshipping according to their conscience. But the privilege made matters worse, and instead of living and worshipping in peace, each in his own way, there 
CHAP. vi. sprang up a fierce contention. The Empire was rent with controversy, and unity had to be secured by the strong arm of the civil power.

Schism of the DonaThe great schism of the Donatists afflicted tists. Northern Africa. They were a fanatical sect, who were excommunicated by the Church, and retaliated by excommunicating all the world. They declared themselves to be God's elect, refused all intercourse with other Christian bodies, and expressed the bitterest contempt for their worship and sacred things. Their fanaticism drew them into every form of licentiousness; while they encouraged one another to look for the second advent of the Lord in one of their own obscure villages.

But the most serious division in the Church was the Arian; so called from Arius, a Presbyter of Alexandria. This city had long been most distinguished as a seat of learning. Built by Alexander the Great, and named after himself, it stands near the most western mouth of the Nile. There the language and philosophy of the Greeks, and especially of Plato, found a congenial home. There the successors of Alexander authorised the translation of the Scriptures of the Old Testament from Hebrew into Greek; which was the work of seventy learned Jews, and hence called the Septuagint. There the learned, and the patrons of 
learning, formed one of the most celebrated chap. vi. libraries in the world. There Jewish Rabbis wrote the books of the Apocrypha.

The most important question, which engaged The Arian the minds of thinking men for three centuries before and for three centuries after Christ, was the Nature of the Word or Son of God. The ancient Greek philosophers had long discussed the Logos or Word as a person or emanation of the Deity, possessed of all the attributes of the Deity. It was warmly disputed at what period the Logos entered upon a distinct existence. The Christians decided the Logos to be no other than the Person of the Son of God, Jesus Christ. St. John accordingly opens his Gospel, in reference to this solemn question, with these words:- " In the beginning was the Word, and the Word was with God, and the Word was God. The same was in the beginning with God. All things were made by Him; and without Him was not any thing made that was made." " And the Word was made flesh, and dwelt among us, and we beheld His glory, the glory as of the Only Begotten of the Father, full of grace and truth." All the disputes of the heathen philosophers with respect to the Logos-all the disputes of Christians respecting Jesus Christ, the Word of God, His Nature and existence-were thus decided by an inspired 
CHAP. vi authority, in harmony with previous revelation; to the effect that Jesus was equal with God, and was God, the Maker of all things; and, therefore, before all things; from everlasting to everlasting - " the same yesterday, to-day, and for ever." This is the question upon which Unitarians have separated themselves from the Church; consequently, they are the successors of the Arians of the days of Constantine.

The Faith of the Church formulated in the creeds.
The first General Council at Nicea.
The Arians, while denying the Godhead of Christ, admitted a likeness between the Father and the Son; but were much divided among themselves as to the extent and nature of this likeness. The Church has formulated in the Nicene and Athanasian Creeds, upon the authority of the Word of God and the decrees of the first General Council, her faith in Jesus as the "very and eternal God, equal to the Father as touching His Godhead, but inferior to the Father as touching His manhood."

Athanasius was the great champion of the orthodox faith in this controversy-a controversy of the deepest importance, involving the honour and majesty of the Son of God, the extent and efficacy of His power to save and redeem mankind, to bless and glorify His people with Himself for ever. The disputes between the Catholic Church and the Arian sects created 
within the Empire intense excitement. It was cHap. vI. with the desire of restoring peace and unity that the Emperor decided on calling a great Council of Bishops and Clergy from all parts of the Christian world, to meet in the city of Nicæa, on the eastern coast of the Sea of Marmora. Three hundred and eighteen Bishops assembled. The Emperor himself was present, occupying a low seat in the midst of the assembly, and took part in the debates. The Synod drew up the Nicene Creed; and, by an almost unanimous vote, expressed, as representatives of the whole Church, their belief "in one Lord Jesus Christ, the only begotten Son of God, begotten of His Father before all worlds; God of God; Light of Light; very God of very God; begotten, not made; being of one substance with the Father, by Whom all things were made." The Arians divided on the words, "being of one substance with the Father"; and voted for the words, "of like substance with the Father." The small minority, who voted for the latter words, were required by the Emperor to accept the decision of the majority.

Athanasius was present at the Council. He $\begin{gathered}\text { athanasius } \\ \text { chosen }\end{gathered}$ was then a young Deacon, and secretary to the chosen $\begin{gathered}\text { Bishop of } \\ \text { Alexandria. }\end{gathered}$ Bishop of Alexandria. He was already distin- . guished as a divine, a preacher, and a contro- 
CHAP. vi. versialist. In a few months he was elected to succeed his old master in the See of Alexandria; a position second only to that of the Bishop of Rome. He was Bishop of Alexandria from 326 to 373 , forty-six years, during which his life was a continual struggle for the true faith and the honour of his Lord against the Arians, and sometimes against the Emperor ; who, three years after the Council of Nicea, was on the Arian side. The Emperor repeatedly tried to effect a compromise, by which the Arians might be received into the pale of the Catholic Church. Synods were convoked, at which many and grievous charges were brought against Athanasius; for example, that he had tyrannised over his Clergy, had deprived Bishops under his authority, had even murdered one, had heaped insults upon, and destroyed the furniture and Communion plate of Arian churches. These charges were refuted; and the Bishop alleged to have been murdered was produced before the assembly alive and well. The Arians, however, being in favour with the Court, Athanasius was condemned and deprived.

Banishment Athanasius now desired an interview with the of Athanasius.

Emperor, that he might plead with him in person. This he was only able to do by boldly and sud- denly appearing before him in the streets of Constantinople, dressed in his Episcopal robes. The 
Emperor was riding in from the country. At first chap. vi. he ordered the Bishop away. Athanasius then prostrated himself on the ground; with eloquent entreaties pleaded for a hearing, and prevailed. But he was not restored to his See. He was sent into honourable exile at the Court of Constans, the Emperor's son, at Treves, in the north-east of Gaul. It was the first of several banishments. Here he was diligently engaged upon those numerous writings in defence of the truth, which he left as a valuable heritage to the Church of after-ages. He was also in regular correspondence with his friends. He had a friend in St. Anthony, resident in a Monastery far up the Nile. He had another in Hilary, the famous Bishop of Arles, in the sonth of Gaul. He had friends in the Bishops of Rome and Cordova. He was beloved by his Clergy; and his popularity was so great and wide-spread in the Church, that he became an object of jealousy to both Constantine and his successors.

Constantine died in A.D. 337, leaving the Empire constantius -again divided-between his three sons and two Emperor. nephews. In a very short time the nephews were murdered; and the three sons-Constantine, Constans, and Constantius-then shared the Empire; Constantine taking the new city of Constantinople and the Central Provinces; Constans 
CHAP. vi. the West, and Constantius the East. Quarrels soon arose between them, which led to the death of Constantine in 341, and of Constans in 351. Then Constantius was sole Emperor. During the struggle between the brothers, the Church enjoyed peace and prosperity. By the favour of Constans, with whom Athanasius had resided in his exile, the Bishop was restored to his See of Alexandria, amidst the joyful acclamations of his people.

Persecution of Athanasius.

But Constantius was of the Arian faction; and now that he was sole Emperor, the peace of Athanasius and of the Church was at an end. The Bishop had steadfastly and successfully resisted all compromise with the Arians-resisted in the teeth of the most cruel persecution, which Constantius had set on foot and encouraged, with the object of bending or breaking him. The Emperor laboured incessantly to destroy him. He influenced against him the Churches of every city and country of the Empire, by every means in his power. He called them together repeatedly; and threatened all who refused to join him in the condemnation of this fearless champion of Jesus Christ. He succeeded in gaining another sentence of exile and deprivation from assembled Bishops; and he took measures at once for the execution of the sentence. 
It was known the Primate was to officiate in CHap. vi. the Church of St. Thomas, in Alexandria, on a His marvelcertain evening. A body of troops was ordered to make an attack on the church, while the assembly was worshipping. As the service proceeded, the tramp of horses was heard by those within. The danger was felt. The Bishop was advised to retire to some place of safety; but he decided to remain. The church was broken open, the worshippers were slaughtered, lights were extinguished, and darkness and confusion prevailed. Nowhere was the Bishop to be found; and the soldiers were obliged to withdraw, baffled in their purpose. For six years afterwards, until the death of Constantius, in A.D. 360, nothing was publicly known of Athanasius, where or how he had escaped. It was a profound secret among his friends-so well kept, that he was able to move from city to city and from country to country, cheering his friends, and encouraging them to continue steadfast in the Faith. After being again restored to his See, on the death of Constantius, he was again banished by the Apostate Julian; and again by his successor Valens.

Gibbon, with all his prejudice against Christi- $\begin{gathered}\text { Gibbon's } \\ \text { estimate of }\end{gathered}$ anity and the Christian Church, has sounded Athanasius. the praises of this holy and unconquerable champion of the Faith, over whom a special 
CHAP. vi. Providence had manifestly spread His protecting wings. The name of Athanasius will be honoured as long as the Church herself shall continue. And the Creed which bears his name has been, and will be, a bulwark against the waves of error, the pride of kings, and the treachery of false friends. The promise has been fulfilled in him, as it is in the Church, for whose pure doctrine he toiled and fought and suffered-" The gates of Hell shall not prevail." 


\section{CHAPTER VII.}

\section{GROWING POWER OF IOMAN BISHOPS.}

TuE chief officer of every Church is its Bishop. Title of But all the Churches are one, in Faith, in Baptism; Unishop, having One Lord, One God and Father of all. It might, therefore, be expected to have one visible head, one universal Bishop. But who of all the Bishops could claim the title, and become the Father or Pope of the Catholic, the universal Church? The influence of the Bishops of Rome had widely and rapidly spread; and their claims were acknowledged over a great part of, but never over the whole Church; although for many ages the Roman Church has appropriated the title Catholic, and many who do not belong to her, with culpable indifference to the meaning of this assumption, allow the title.

The assumption makes all who are not of assumed the Roman Church to be not of the Church. It of Rome. brands all who do not belong to her as heretics and schismatics, and outside the ark of salvation. It is a monstrous assumption; and the more 
CHAP. viI. So when those who are outside are more in harmony with the Faith once delivered to the Saints, and with the practice and discipline of the early Christians.

Unwarranted by Holy Scrip-
ture.

Holy Scripture is against the supremacy of the Bishop of Rome. It is against the traditions of that See. The Roman Church is modelled upon the political systems of this world. The Kingdom of Christ is a spiritual kingdom, and not of this world. Worldly glory and wealth are not to be the aim of His people and ministers. The Popes of Rome are not the vicars (as they pretend and call themselves) of Jesus Christ on earth. They are far from being counterparts and reflections of Him. The Roman Church is modelled, for the most part, on the plan of the Empire; like the Emperors, the Roman Bishops have claimed authority, and sometimes with success, not only over all other Bishops, but over all other sovereigns and princes of the world.

Grounds for the

Governors of the Provinces of the Roman assumption. Empire were obliged to allow an appeal to the Emperor. The Apostle appealed from the Governor Festus to the Emperor. In like manner, the Bishops of the several Provinces were required to allow an appeal to the Bishop of Rome. Rome was the capital of the Empire; and it was 
also declared to be the capital of the whole chap. vir. Church; the See of St. Peter, who was designated Prince of Apostles, the Vicar of Jesus Christ, the first Bishop of Rome, and the prototype of all future Bishops of Rome. And there was a disposition in the Western Church to admit these pretensions. But the East, and especially the cities of Antioch, Alexandria, and Constantinople, were determined opponents of such pretensions. The two former cities had been the capitals of great and ancient kingdoms; and the latter was the new capital of the Empire, intended to supplant the old capital of Rome. Although the Empire had been divided into East and West, Constantius, the Emperor of the East, had brought the West under his power, and this tended to lower the position and authority of the Bishop of Rome in the eyes of the Eastern Churches. The race for the first place ultimately remained with Rome and Constantinople; the Western and Eastern Churches, following these respective leaders, came to be known as the Greek and Roman Churches.

The Bishops of Rome were often men of great was st. ambition. They regarded St. Peter as the chief Pishop of of the Apostles, and the first of their line. But, according to the New Testament, St Paul had a better title to the headship of the Roman Church. 
CHAP. vII. It is certain that he was at Rome; not so in regard to St. Peter. He was the Apostle of the Gentiles; St. Peter of the Circumcision. He wrote a most important Epistle to the Romans ; not so St. Peter.

Pope Victor. By the end of the second century, Bishop Victor threatened excommunication of all Churches which did not conform to the practice of Rome with respect to the time of observing Easter-a stretch of authority which was condemned by the Western Bishop Irenæus, although he himself approved and followed the Roman rule.

Pope Bishop Stephanus, A.D. 253, was appealed to stephanus. by two Bishops of Spain, who had been deposed by their people; while those who had deposed them appealed to Cyprian, Bishop of Carthage, who claimed an authority equal to that of the Bishop of Rome.

Pone Leo the Great.

The Emperor Valentinian III. favoured the supremacy of the Roman See, as being the primacy of the Blessed Peter, Prince of the sacerdotal crown; confirmed by the dignity of the Roman city, and by the authority of the holy Nicene Council. That Council had recognised a patriarchal supremacy of Rome, Alexandria, and Antioch, in their respective districts. Valentinian was greatly influenced in this matter by Bishop Leo the Great (A.D. 440-461); 
whom Hallam describes as one of the most chap. vir. ambitious Pontiffs. The title Pontiff was an Imperial title, proclaiming the Emperor to be supreme in all matters of religion and religious worship. This title the Roman Bishops assumed as an assertion of a similar position in the Christian Church. In all questions of faith and practice, they maintained that the final judgment rested with them.

A certain Bishop appealed from Hilary of Leo's decree. Arles to Leo the Great of Rome, who went so far as to depose Hilary, the champion of the freedom and independence of Churches, and the good friend of Athanasius. Leo wrote-“We decree, with our irrevocable sanction, that it is unlawful for any Bishop in France, or of any other Churches, to do anything contrary to ancient custom, without the authority of the venerable Pope of the Eternal City; but that they receive for law whatever the Apostolic See has, or shall have, sanctioned."

Innocent the First, in 402, demanded to be Innocent I. consulted whenever any question of any doctrine was raised in any Church. Gelasius, in 492, claimed the final decision of all religious questions for the Apostolic See.

The greatest assistance was rendered to the Independent pretensions of Roman Bishops by the mission- Britain. 
CHAP. vir. aries of the Roman Church. The island of Britain will afford an illustration of this. A Church had been established in the island at least as early as the third century. British Bishops were present at the Council of Arles in 314. St. Alban was a Martyr for Christ in 305. The Pelagian heresy took its rise in the British Church ; and by that Church the Bishops Germanus and Lupus were invited over to refute that heresy.

Anglovited into Britain.
Saxons in-

At the beginning of the fifth century the island was troubled by incursions from the north into the south. The Roman soldiers ceased to be a protection, and were wholly withdrawn to guard Rome and Italy. The Britons were driven to seek assistance from the Angles and Saxons of the Continent. These, having beaten back the Picts and Scots, turned their arms against the Britons, seized their country for themselves, and invited more of their own countrymen to follow their example. From the numbers of the Angles who settled in the east of Southern Britain, that part of the island came to be called AnglelandEngland.

Gregory the Great in the slave-market
of Rome.
Bishop Gregory I. of Rome heard of the spiritual darkness of the Angles and Saxons, their ignorance of Christianity, and their gross idolatry. He was desirous, before becoming Bishop, that a mission should be sent to Eng- 
land. On a certain day, the market-place of chap. vir. Rome was filled with merchandise, and people flocked thither to buy. Amongst them came Gregory, who saw some boys put up for sale, of noble countenance, fair complexion, and with gracefully flowing hair. When he saw them, he inquired of what country they were. It was said, "Of Britain." Again he inquired, if the islanders were Christians or Pagans. "Pagans," was the answer. Then, heaving a deep sigh, he said-"Alas for pity! that the author of darkness should possess such a people; and that men of such graceful form and bright features should have their minds void of inward grace." Again he asked the name of the people. "Angles," was the answer. "Well," said he, "they have angelic faces, and ought to be co-heirs with the Angels." But of what province are they?" he asked. "Deiri is their provincial name," was the answer. "Well," he said, "they will be rightly named Deiri, when they are delivered from the wrath (de ir $\hat{a})$ of God into the mercy of Christ. What is the king of that province called?" " Ella," it was said. Playing on the name, he said, "Alleluia, the praise of God ought to be sung in those parts." Gregory then went to the Bishop, and entreated that a mission might be sent to convert the people to Christ. 
CHAP. vir. He was himself prepared to go, if that were the Bishop's pleasure. But he was not permitted, such was the favour of the Roman people towards him. Soon the Bishopric of Rome became vacant, and it was conferred on Gregory. Then he sent the Mission of Augustine.

Mission of Augustine.

Augustine was accompanied by forty brethren. On their journey through France, the party suddenly became panic-stricken at the appearance of some barbarous people, through whom they had to pass. The danger seemed to threaten their very life. They begged of Gregory that they might return, and be sent on some less dreadful enterprise, less toilsome, and with better prospects of success. He replied with these words:- "It had been better not to have begun this good work, than, having begun, to leave it off. With God's help proceed, and fulfil your task; and be not afraid of the way, or the work, or the people. Proceed in the Name of God, remembering the greater the work the greater the reward." He bade his companions to obey their leader in all things, and concluded with the prayer- "God Almighty protect and keep you, my most dearly beloved." $\mathrm{He}$ also wrote to the Bishop of Arles to further them on their way. Thus encouraged, they arrived in Britain. They landed in Kent,in the Isle of Thanet. 
Ethelbert, the King of Kent, had extended chap. vil. his sovereignty northward, as far as the river Ethelbert, Humber. The missionaries acquainted the King king of Kent. with their arrival. They had come with the best news; with the promise of eternal joy to those who obey, and of an endless kingdom with the living and true God.

The King had married a Christian lady- Reception of Bertha, daughter of the King of Paris. She Mission. had the attendance of a Christian Bishop, and the privilege of a Christian place of worship, although her husband was a Pagan idolater. Augustine was commanded to appear before the King, who appointed him a residence. On their way into the royal presence, the missionaries carried before them a silver cross, as their standard; and a banner, on which was painted the image of the Saviour. They offered up prayers for their own salvation, and for the salvation of those for whose sake they had come. They preached before the King and his assembled people. Then said the King, "Fair are the promises which you bring; but as they are new, I cannot yet assent to them, and leave the worship which I and my nation have long observed. But since you have come a long way; and, as you believe, to do us good, you may remain with us, and do whatever good you are 
CHAP. vir. able. All things needful for your support shall be supplied. Convert as many of my people as you can." As they entered the city of Canterbury, soon to be the See of an Archbishop and of the Primate of all England, but at present the capital of Ethelbert, they sang this hymn:"We pray Thee, O Lord, of Thy great mercy, turn away Thine anger from this people, and from Thy holy house ; for we have sinned. Amen."

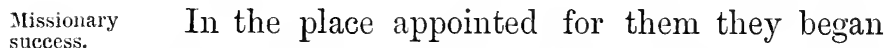
their apostolic labours with prayer, fasting, watching, preaching. They despised the things of the world, providing only such things as were necessary. They were prepared for all adversities; even to die for the truth. Some believed, and were baptized.

Augustine lirst Archbishop of

On the east of the city, there was a church Canterbury. dedicated to St. Martin, which had been built while the Romans ruled in Britain, in which Queen Bertha worshipped. To this Augustine and his company resorted, and there performed the sacred offices of religion. The King was finally won over to Christianity, and was baptized. The means of grace were now rapidly multiplied; churches were built and restored in every direction. Multitudes followed the example of their sovereign. None were under compulsion; yet the King naturally favoured 
those of his subjects, whom he now counted as cusp. vil. fellow-citizens in the Heavenly Kingdom. He liberally supplied the temporal needs of the new church-even surrendered to Augustine his capital, and chose another for himself. By Gregory the First's instructions, Augustine returned to the Continent; and was consecrated the first Archbishop of Canterbury by the Bishop of Arles.

Augustine, at the same time, referred certain

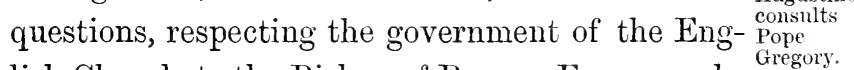
lish Church, to the Bishop of Rome. For example "What distribution should be made of the offertory?" to which the reply was, "Let one part be for the Bishop, one for the clergy, one for the poor, and one for the repairs of the Church fabrics." Another question was respecting the custom or form of service in Churches. "Choose," says Gregory, "what custom seems best; all things which are good, take and bind them together as in a bundle, and lay them up in the minds of the Angles."

The new Archbishop was then supplied with a The Pallium. pallium or cloak - a symbol of the authority which the Roman Bishop confers on those whom he provides therewith. York, too, was made York made an Archbishopric, with authority similar to bishopric. that of Canterbury; the one See, to which a 
CHAP. vir. Bishop was first appointed, having precedence of the other.

Gifts and letter of Giregory to Augustine.

Letter of Gregory to Ethelbert.

Along with sacred vessels and other gifts, Gregory sent a letter to King Ethelbert, recommending the Church to his royal favour; another to Augustine, warning him not to be puffed up by the success with which God had blessed his ministry. His words were: "Whatever thou hast received, or shall hereafter receive, consider' not as given to thee, but to them, for whose salvation they were given."

Addressing the King as his "most glorious and excellent son," Gregory wrote as follows: "As once the most pious Emperor Constantine brought his subjects under the dominion of our Lord Jesus Christ, whereby he excelled all his predecessors; so your glory will be to spread the knowledge of the One God, Father, Son, and Holy Spirit. You will exceed in praise all your predecessors, the ancient kings of this nation; and the more you purge yourselves of individual and national sins, the better will you pass the scrutiny of the Almighty Judge." He concludes the epistle with an earnest exhortation to listen to whatever Augustine shall advise, diligently to keep it in mind, and to perform it with filial devotion. 


\section{CHAPTER VIII. \\ GOTHIC INVASIONS.}

THE invasions of Britain by the Angles and Migrations Saxons were part of a general disturbance through- into Europe. out Europe. The movement began in the northeast of Asia, on the confines of China. The Huns were a bold and restless people, who preyed on their neighbours, and drove before them, or destroyed, the inhabitants of the lands which they ravaged. They journeyed westward, arrived in Europe towards the end of the fourth century, and laid waste those parts which were occupied by the Goths, then divided into Visigoths and Ostrogoths. The Huns dispossessed and expelled them, and the Goths were obliged to seek a home elsewhere. The Visigoths moved towards those limits of the Roman Empire which were on the great river Danube.

Christianity had already spread amongst the Ulphilas the Gothic tribes, through the labours of Ulphilas, the Goths. who has been named "the Apostle of the Goths." Ulphilas had been consecrated their Bishop by 
chap. vili. Eusebius of Nicomedia, after which he devoted himself heart and soul to the conversion of his countrymen. Partly through the pressure of the Huns, and partly from a desire to separate themselves from their heathen fellow-countrymen, the Christian Goths petitioned the Emperor for a home within the Empire. The petition was carried to the Emperor Valens by ambassadors, the chief of whom was Ulphilas, a man to whom the nation was indebted for the use of letters, for a translation of the Scriptures-excepting the Books of Kings, which were omitted from a fear of exciting too much their martial courage, "which required the bit rather than the spur." The Emperor was at Antioch, forcing on the inhabitants the Arian theology, which Ulphilas himself adopted, on condition that the petition was granted, and lands were assigned for the occupation of the Goths. The Emperor, however, demanded a surrender of their arms and their children, whom he distributed over the provinces of Asia.

The Goths cross the Danube.
On these conditions, the Goths were allowed to cross the Danube, and to "settle in the province now called Bulgaria. But besides the peaceloving disciples of Ulphilas, thousands of their heathen brethren took advantage of the Emperor's favour, and for days and nights there was crossing 
and recrossing, many being drowned through the CHAP. viII. force of the current. Whilst one of the leaders raised the standard of Christianity, another raised the standard of Woden, the pagan god of war, before whose image all were required to bow down, on pain of being burnt with their wives and children.

The Goths, after they had entered upon the Defatand promised land, were much dissatisfied with the valens. behaviour of the Roman Governors and military officers; their bold and independent spirit could not endure Roman insolence. They rebelled, and revenged themselves by a march on Constantinople, the capital. The Emperor Valens marched out in hot haste, and met them in the plains of Adrianople, where, after a disastrous battle, the Emperor took refuge in a private dwelling, which was surrounded and set on fire, and all within perished by the flames.

The East was now without a ruler, and the Theodosin Emperor of the West appointed as successor of the Great Valens, Theodosius, known as Theodosius the Great; the only man, as it was believed, able to cope with the Goths. He met them with promises of friendly and honourable treatment, gave their chiefs a position in the imperial service, honoured their leader Alaric, and settled on them the fertile province of Roumelia. They were now pacified, 
CHAP. viII. and Theodosius turned his attention to the Church. Since Constantine, all the Emperors, except the Apostate Julian, had been Arians. But Theodosius held the true faith of the Nicene Creed, and was as zealous in pressing it upon his subjects as his predecessors had been in pressing on them the Arian doctrines.

The Second

General

A Bishop of Constantinople, named MaceCouncil. donius, believed in the Godhead of Jesus Christ, but denied the Godhead of the Holy Spirit. The matter was submitted to a Council of 150 Bishops at Constantinople, summoned by Theodosius in the year 381. It was there decreed to be the teaching of Holy Scripture that the Holy Spirit is co-equal with the Father and the Son, that the Father is God, the Son is God, and the Holy Ghost is God; and the following words were added to the Nicene Creed: "The Lord and Giver of Life, who proceedeth from the Father and the Son, who with the Father and the Son is worshipped and glorified, who spake by the prophets."

Gregory Nazianzen, Bishop of Constan-

Theodosius vigorously set to work to stamp tinople. out the Arian heresy. He called Gregory Nazianzen to the See of Constantinople from his native Cappadocia. Nazianzen was obliged for a time to preach and minister in a private room, which he named Anastasia, signifying thereby 
the resurrection of that purity of faith and chap. viII. doctrine which the Arian and Macedonian heresies had destroyed. It was afterwards enlarged, and at length became the magnificent Church of St. Anastasia, from whose pulpit he proclaimed the pure Word of God with power and eloquence. The heretical Bishop was ordered by Theodosius to surrender his See, palace, and churches to Gregory and the orthodox party. The good man did not feel very happy in his exalted position, and spoke of himself as being more of a wolf than a shepherd. Gibbon describes him as "the most pious and eloquent Bishop of the age, a true Saint and Doctor of the Church." He was soon the victim of malice and envy, and for the sake of peace he resigned his See and retired to his home in Cappadocia, where he spent the remaining eight years of his life in writing poetical and devotional treatises. At the same time the Emperor published and enforced the decrees against the Arians, prohibited their religious meetings, appointed inquisitors, whose duty was to bring offenders to justice.

At this time there arose one of the most dis- Ambrose tinguished lights of the early Church-Ambrose, of Milan. who was suddenly called by the citizens of Milan to be their Bishop, although he was not yet baptized. It was no uncommon practice for such as 
CHAP. viII. were brought up in Christianity to delay their Baptism. The Emperor Theodosius was not baptized until the first year of his reign. Ambrose had filled the office of chief magistrate of Milan with great distinction, and with much satisfaction to the people. His call to be their Bishop in spite of all his remonstrances, was persisted in, until he regarded it as a voice from Heaven.

Ambrose resists the Emperor Valentinian.
Milan belonged to the Western half of the Empire. The Western Emperor Valentinian, who was of the Arian faith, often resided in Milan. On such occasions he requested that there should be a church in the city for those of his own faith. This, as Diocesan, Ambrose resisted. His answer was: "The palaces of the earth might belong to Cresar, but the churches were the Houses of God; and within the limits of his Diocese he himself, as the lawful successor of the Apostles, was the only minister of God. He would sooner die as a Martyr than yield to the impious sacrilege of allowing the Arians the use of the Houses of God. And when the Emperor and his Arian ministers arrived in Milan, their lives were in imminent danger, and were only secured by the intercession of Ambrose. All Milan sided with the Bishop and against the Emperor; and when the Bishop was entreated by some to comply with his 
sovereign's request, he answered fearlessly that chap. vin. his life and fortunes were in the hands of the Emperor, but he would never betray the Church of Christ nor degrade the dignity of his Episcopal office. Force was then resorted to. Gothic barbarians in the service of the Emperor were ordered to occupy the Cathedral. The Archbishop met them at the entrance, and with a voice of thunder pronounced their exconmunication. Then, with the tone of a father and a master, he asked if they were enlisted under the Emperor for the purpose of invading the house of God. The soldiers were awed, and withdrew; while Valentinian and his mother, at whose instigation he had acted, retired from Milan.

The Arians were still determined that Ambrose Rebellion in should have no peace. They secured against him a sentence of banishment. But he boldly refused to obey, and in this his people supported him. They guarded his person, and secured his palace and Cathedral. A rebellion against the Western Emperor broke out in Britain, and spread rapidly over France and Italy to the walls of Milan. The only hope of stemming the tide was to call in the assistance of the Eastern Emperor, Theodosius. This assistance was granted; and, after a decisive victory, Theodosius rested for a time in Milan, arranging the affairs of the whole 
Char. vin. Empire, having become sole Emperor through the death of his Western colleague.

Massacre of the Thes. salonians.

While Theodosius was at Milan, a terrible tragedy was enacted at Thessalonica. A sedition there had been caused by the conduct of a favourite charioteer in the public games of the Circus. This man had seen, and at once desired to possess, a beautiful boy, the son of a Gothic General; who was a favourite officer of the Emperor. The Goth declined to give up his boy; and the Thessalonians, in their mad rage on seeing their favourite thus disobliged, seized the General, murdered him and several of his principal officers, and then dragged their mangled bodies through the streets of the city. Theodosius, hearing what had happened, was filled with anger and vexation, and declared that the shameful act of the Thessalonians should not be expiated but with their blood. Hesitating a while between clemency and revenge, he was finally instigated to revenge. He issued an order for a general massacre, which was executed with such speed, that the relentings which immediately followed were too late. The inhabitants of the doomed city were invited into the Circus ; and, at a signal, were massacred by the soldiers of Theodosius. The most moderate estimate states the number of the slaughtered to be seven thousand. 
What was the conduct of Ambrose on this chal'. vill. occasion? He had great influence with Theo- Penance of dosius, and was regarded by him even with affection. Hearing of the massacre, Ambrose retired from Milan, and avoided the Emperor's presence. Feeling that silence was likely to make him appear a partaker of his guilt, he indirectly excommunicated the Emperor. He informed him that he had been warned by a vision, never to give the Holy Eucharist into those hands which were still polluted with the blood of an innocent people. Theodosius was deeply affected, and bitterly lamented his rash fury with all its direful consequences. He came to the Cathedral to join in its service, but was met at the porch by Ambrose; who, as the ambassador of Heaven, declared that his private repentance was not sufficient to atone for a public crime. "You have imitated David in the crime; imitate him in his repentance." Thereupon Theodosius made a public confession of his guilt; and, humbled to the dust, and stripped of all the ensigns of royalty, he placed himself in a mournful and suppliant posture in the middle of the Cathedral, and solicited with tears and sighs the forgiveness of his sins. After eight months, he was restored to the communion of the Church.

Of this event, Gibbon remarks :-_" Posterity 
chap. vir. has applauded the virtuous firmness of the Arch-

Gibbon's obscrvation. intereedes toran tria usurper. bishop; and the example of Theodosius may prove the beneficial influence of those principles, which could force a monarch, exalted above the apprehension of human punishment, to respect the laws and ministers of an invisible judge."

Although Ambrose had firmly resisted all compromise with the Arianism of the Western Emperor, when that Emperor died, he pronounced over him the charitable hope of his entrance into the mansions of bliss. The usurper, who succeeded for a short time, had to thank the good and brave Bishop of Milan. For, when overthrown by the forces of Theodosius, the clemency of the conqueror was secured by the intercession of the Bishop.

The

It is a belief, which has been long entertained, and is widely prevalent, that the Church is indebted to Ambrose for the hymn, "Te Deum." We are told that, probably from very ancient times, psalms or canticles were intermingled with the reading of Scripture in the public service. Many of them occupy, as nearly as possible, the places where they have been sung for centuries. The first of these is the hymn, "Te Deum Laudamus." In the Breviary, it is called the Psalm "Te Deum, or the Canticle of Ambrose and Augustine," from the old legend 
that, at the Baptism of Augustine by Ambrose, CHAP. virI. it was composed by inspiration, and sung alternately by the two Saints. Most probably, however, it was composed in the Gallican Church. In an ancient manuscript, it is entitled "The Praise of the Holy Trinity, which Saints Augustine and Ambrose composed," and is preceded by the couplet, "Praise the Lord, ye children; Praise the Name of the Lord." 


\section{CHAPTER IX.}

GROWING CORRUPTIONS IN THE CHURCH.

The march of Alaric upon Rome.

Theodosius the Great died A.D. 395, and left two sons to succeed him-Arcadius in the East and Honorius in the West. From this time, the Eastern half of the Roman empire remained distinct from the Western, and had a continuous and separate existence until its destruction by the Turks A.D. 1453. The two halves had been united under one head for the last time by Theodosius. His strong hand and wise government had kept in check the barbarous Goths, but on his death they aimed at a wider and more independent dominion within the Empire. Their King Alaric went from victory to victory up to the very walls of Rome. The city maintained a siege for some time. The inhabitants of the surrounding districts fled before the savage warriors. The siege was scarcely less destructive of life and property than that of Jerusalem by Titus. The daily allowance of bread was gradually diminished until there was none to divide. The widow of 
Theodosius, as far as her means would enable her, chap. Ix. met the wants of the hungry and the perishing. Many lived on the bodies of those whom they had murdered, and even mothers tasted the flesh of their slaughtered infants. Thousands died of want in the houses and in the streets. The air was infected with the stench of unburied corpses, and pestilence followed upon famine. Messengers were sent to Alaric to arrange the terms of a capitulation. With a lofty tone they said that if he would not treat with them on reasonable terms, an innumerable multitude would march out against him from the city. With a loud insulting laugh the King replied, "The thicker the hay, the easier it is mowed." He then named the price of his withdrawal. "All the gold and silver, all the rich and precious moveables, all the slaves." "What," asked the ambassadors, "will you leave us?" "Your lives," was the reply. A stipulated sum, however, was agreed upon, and Alaric withdrew, but for no long time.

For the sake of his own safety, the Emperor Rome Honorius had fixed his residence at Ravenna, onsty sursituated in the north-east of Italy, near the coast, and surrounded by extensive marshes. When he heard of the agreement made with Alaric by the Roman Senators, he scorned to give 
char. Ix. his assent to such exorbitant demands. The Goths were soon again at the walls of Rome, the gates of which were treacherously opened, and the inhabitants delivered up to the licence and fury of the savage enemy. One restriction was laid upon the soldiers by their leader, which illustrates the power which Christianity had already acquired over these fearless and cruel invaders. Respect was to be shown for the Churches of St. Peter and St. Paul. One of the Gothic soldiers beheld with wonder the valuable consecrated vessels. "These," he was told, "belong to St. Peter, and if you presume to touch them, the sacrilegious deed will remain on your conscience." The soldier was struck with a reverential awe, but, for further security, an order came from Alaric that they should be solemnly removed to one of the favoured churches. This was done with the singing of Psalms and a public procession, which was swollen by Christians of all ranks issuing from their houses.

The Sar $k$ of Rome.
Nevertheless, the destruction of the city went on ; and as Rome had done to others, so now it was done to her. The streets were filled with dead. Slaves rose up against their masters to the number of 40,000, and visited upon them a terrible revenge for the lashes they had received. The massive buildings and the statues of the 
gods, which adorned the Forum, were levelled cHap. Ix. to the ground. In this terrible crisis were to be seen many bright examples of Christian fortitude and self-sacrifice. This sack of Rome was regarded by St. Augustine, Bishop of Hippo, and the great Christian theologian of that age, as a Divine judgment on the city for its luxury, its pride, and grandeur, and as a triumph for Christ. He asks whether, in Rome or elsewhere, the idols of the heathen had been able to hold their own, or preserve their cities from Divine wrath. Many of the Christians fled for safety and succour to distant parts. Some found refuge with St. Jerome, who at that time occupied a retired cell in Bethlehem, the Saviour's birthplace, where he was engaged in translating the Holy Scriptures from their original language into Latin. This translation, commonly known as the Vulgate, has from that time to the present been the authorised version of the Roman Catholic Church. Many of those who fled to him from the ruined capital of the Empire were members of illustrious families, and excited his compassion by their misfortunes. This terrible visitation occurred in August 410, and was considered by the Christian Church at large as a certain sign of the immediate end of all things.

While the Visigoths, under Alaric, were work- 
CHAP. Ix. ing devastation in the capital of the West, the

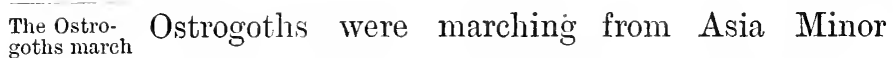
on Constantinople. - where they had been located by Theodosiuson Constantinople, the capital of the East. Here the Emperor Arcadius was betrayed by one of his chief ministers, who was a Gothic General. The chiefs of the enemy had an interview with the Emperor in a church, a little distance from the city. It was agreed that the Ostrogoths might transfer themselves from Asia Minor into Europe, and that their leader should be a MasterGeneral of the empire. The Goths were Arians, and demanded the use of one of the city churches. This demand produced an uproar among the Catholic Christians, and disorder throughout the city. The gates were suddenly closed by the inhabitants, and the people rose in a mass against the strangers, 7000 of whom perished.

Clirysostom Bishop of Constantinople.
It was about this time that the famous $\mathrm{T}$ ohn Chrysostom was appointed to the See of Constantinople. It would appear that bribery had already much to do with the election of a Bishop, who was then elected, not by the sovereign, but by the people. The election of Chrysostom, however, was purely the result of his own superior merit. John was his Christian name, and Chrysostom-the "golden-mouthed"was added, because of his marvellous eloquence. 
Eutropius, the Prime Minister of Arcadius, chap. Ix. and an historian of the empire, had met with Popularity him in Antioch, where he had established his and writer. reputation as a preacher of the Gospel. Eutropius invited him to Constantinople. The people of Antioch were unwilling to lose him, and he had to be hurried away secretly in a post-chariot. He surpassed the sanguine hope of his new flock. Of a noble and wealthy family, he had been tended and educated by his mother with the greatest care. He had for his tutor Libanius, the great master of rhetoric, who, being a heathen, complained that his pupil might have succeeded him, had not the Christians stolen him away. He was baptized, and then left the study and profession of the law for the Church. Six years he lived the life of a severe recluse, and he continued to live, after he became Archbishop, by the same rule, taking his meals, which were of the simplest fare, alone, and applying the income of his See to the building of hospitals. Numerous monuments of his earnest labour in the Church have been preserved. Not less than one thousand sermons have came down to us, remarkable for eloquent and copious language, an inexhaustible fund of metaphors and similitudes, of ideas and images, engaging the human mind and heart in the service of virtue, and 
CHAP. Ix. exposing with irresistible force the follies and vices of Court and people.

Degeneracy of Court and people.

He raised against him two classes of enemies -those who envied his high position, and those whom he offended by his faithful reproofs. From his pulpit in the Cathedral of St. Sophia, he declaimed against the degeneracy of Christians, and the vices of the wealthy. He spared neither the minister of State, nor the Court favourite, nor the magistrate. $\mathrm{He}$ denounced the corrupt lives of the Empress Eudoxia and her ladies. He exposed to public detestation both offenders and offences. The Court, the Clergy, the Monks - all banded against him. Strict ascetics he commended, but degenerate Monks he lashed with severity. To persuasion he added authority. In his visitation of his Asiatic Churches, he deposed thirteen Bishops for corruption, simony, or licentiousness. So great was the flood of iniquity which had gathered and spread over the Church, after one short century of power and prosperity! The enemies of Chrysostom were furious. They denounced him as the tyrant of the Church. A conspiracy was raised against him, headed by Theophilus, the Bishop of Alexandria-a city which had been to some extent eclipsed by the elevation of Constantinople. 
A Synod of Bishops met, at which Theophilus chap. Ix. presented seven articles against Chrysostom, who $\begin{gathered}\text { Chrysostom } \\ \text { persecuted }\end{gathered}$ was summoned to appear and answer in his by Eudoxia. defence. He, however, declined to trust himself amongst his adversaries; and forthwith they pronounced his condemnation and deposition. For this they sought the sanction of the Emperor, representing him as a reviler of the Empresscalling her Jezebel. The imperial officers seized and conveyed him into banishment, from which after two days he was recalled. His return caused great rejoicing among the citizens. It became dangerous for any of the countrymen of Theophilus to appear in the streets of Constantinople. Theophilus himself fled in haste from the city, which was now in a state of sedition against the Empress, upon whom the blame of Chrysostom's persecution justly rested. For the sake of peace, she was obliged to entreat the Emperor to restore the Archbishop.

This was a triumph for Chrysostom, who re- Restorei turned to his duties, still declaiming against the to his Sice. vices of the Court, and specially against the profane honours given to the statue of the Empress. It was reported that in one of his sermons he had used these words: "Herodias is again furious; Herodias again dances. She once more requires the head of John." The truce was soon broken. 
chap. Ix. The former sentence of deposition was renewed. Troops were stationed to maintain order in the city. It was Easter Eve. The administration of Baptism was rudely interrupted; the Cathedral occupied; and, on the following day, it was in flames.

In exilc. Chrysostom quietly submitted to retire from the city, to a small and desolate town of Armenia. It was a difficult and weary march of seventy days in the heat of summer. The hope was that he might perish on the way. He arrived in safety, and spent there the three remaining and most glorious years of his life. His character rose still higher in the estimation of the Church. His faults were forgotten; his praises were sounded by every tongue. In his retreat he kept up an extensive correspondence with the most distant provinces, exhorting congregations to be faithful; that idol temples should be destroyed, heresy extirpated, Christian missions extended, great questions transferred from provincial Synods to a free and General Council. The death of Another cruel order was issued, by which he
Chrysostom.

was banished to a still more remote and desolate region, on the farthest shore of the Black Sea, in the neighbourhood of the wild, uncivilised tribes of the Caucasus-an order which was so cruelly executed, that he perished on the way (A.D. 407), 
in the sixtieth year of his age. His innocence chap. $\mathrm{IX}$. and great merits were universally acknowledged by the next generation. His remains were transported, thirty years after his death, from their obscure resting-place to the royal city. They were met by Theodosius the Younger, son of Arcadius and Eudoxia, who fell down before them, and implored forgiveness for the injuries which had been done to the Saint. Within a year of Chrysostom's death, the haughty and criminal Eudoxia died in childbed; her end being applauded as a mark of the righteous judgment of God for her cruel persecution of a good and faithful minister of Christ. 


\section{CHAPTER X.}

THE MIRACLES OF SAINTS.

Christianity confirmed by Niracles. first preaching of the Gospel to a hostile and barbarous people, special assistance is needed from Heaven. Such assistance, wherever and whenever sought by faith and prayer, is granted. The mission of Moses to the King of Egypt was one of danger, which was overcome by the gift of miracles, performed in the King's presencemiracles of such a kind, as commanded the attention and respect of the King. The Twelve Apostles and the Seventy Disciples were armed wth similar powers. At the Ascension of our Blessed Lord, the Apostles were charged to go into all the world, and preach the Gospel to every creature. The charge was accompanied with a promise-_" $\mathrm{He}$ that believeth and is baptized shall be saved; but he that believeth not shall be damned. And these signs shall follow them that believe: In my name shall they cast out devils; they shall speak with new tongues; they shall take 96 
up serpents; and if they drink any deadly CHAP. $x$. thing, it shall not hurt them; they shall lay hands on the sick, and they shall recover." Accordingly, miracles were performed by the first teachers of Christianity, by which their testimony to Jews and heathen was confirmed. At Lystra St. Paul healed an impotent man; at Philippi an earthquake opened the prison doors; at Malta he shook off from his hand a venomous reptile, and felt no harm.

The Venerable Bede, whose truthfulness as a Bede's tesnarrator is praised alike by believers and un- timony to believers, records many instances of the same kind of confirmation, which was given to the message of the Gospel to the Britons and Saxons. It was the belief at any rate of the age to which they belong, that miracles were wrought in the Name of the Blessed Trinity, by those Apostolic messengers, who carried their lives in their hand, for the sake of a nation's conversion to Christ.

On his way to martyrdom, at the crossing of siracle of a stream, St. Alban found the water dried up st. Alban. before him. And when he arrived at the hill on the other side, where he was beheaded, and being thirsty, there sprang up at his feet a fountain of water.

Germanus, who had been invited over from 
CHAP. x. France into Britain to stay the mischief of the

Germanus calms the wind and sea. Pelagian heresy, had the assistance of miracles. When crossing the English Channel, his passage was safe and speedy for some distance. But suddenly burst forth the rage of demons, who envied the salvation of the island people. They raised storms and darkness and fierce winds. The sailors were baffled and overcome. The captain was worn out with toil and watching. All hope was gone. The storm grew still more violent. At length all eyes turned to Germanus; who, in the Name of the Trinity, restrained the fury of the winds, and the violence of the waves. Help came from God; evil demons were put to flight; the winds were favourable; and all arrived safe at the desired haven.

Restores the might of a magistrate's of one of the chief magistrates, whom Germanus

During his ministry, we are told of a daughter danghter. confessed their inability, and joined their prayers with those of her parents, beseeching Germanus that he would heal her. Then he, full of the Holy Ghost, invoked the Blessed Trinity; and her sight, of which she had been deprived ten years, was restored-to the joy of her parents and the wonder of the people, who had witnessed the miracle, and were thereby confirmed in the pure doctrine of Christ. 
Great virtue was attributed at the same period cHAP. x. of the Church's history to the intercession of Virtue departed Saints, and to the use of relics, in the to relics. cure of the afflicted. It is difficult for us at this day to enter into the feelings of those who placed such value upon the ashes of the departed. The Twenty-second Article of the Church has stated that the Romish doctrine concerning Purgatory, Pardons, Worshipping and Adoration as well of Images as of Reliques, and also Invocation of Saints, is a fond thing vainly invented, and grounded upon no warranty of Scripture, but rather repugnant to the IVord of God. And we must, therefore, grant that the Deceiver of mankind succeeded in imposing upon the ignorant and superstitious of every land for many generations.

The dead body of Elisha caused the resurrec- Superstitinn tion of a dead man. Our Blessed Lord anointed general with clay the eyes of a blind man; and then middle ages directed him to wash in the Pool of Siloam. He washed, and was restored to sight. It was such examples upon which was grounded the belief in the virtue and efficacy of dead matter, and especially of the mortal remains of the Saints. The miracles recorded as resulting from the use of relics, from the fourth to the sixteenth century, are innumerable. Every new Church 
CHAP. x. was provided with the relics of some holy person, or with something rendered sacred by association with them. It was not the peculiar belief of one Church. It leavened the whole Church. It is the peculiar reproach now of the Roman Church, that she, notwithstanding a reformation of other Churches in this and other matters, still cherishes a belief in the efficacy of relics, and refuses to cast off this and other superstitions.

Superstition amongst the learned.

Relies provided for new churches.
If Scripture forbids such a belief, the Roman Church falls back upon St. Augustine and the Venerable Bede-the great, but not infallible lights of their own day, and of the ages that followed. In the dreary times of ignorance and superstition, no marvel that many even among the pious and learned should be misled by an ignis fatuus.

The Emperor Arcadius provided relics for the new churches of Constantinople, which was a new city, and not possessed of a long roll of Saints and Martyrs, like Rome, with their tombs lining the Appian and Ostian Roads. The remains of Saints Andrew, Luke, and Timothy were brought from their quiet and obscure resting-places. The tomb of the Prophet Saniuel in Palestine was opened, and the dust of it conveyed with great pomp to Constantinople. The whole 
way was thronged with multitudes, who devoutly cнap. $x$. looked upon this treasure, as a new source of health and life to the city, the empire, and the world. A similar transfer was made of the remains of the first Martyr Stephen to Jerusalem, and a distribution made from thence to all parts of the world.

Some there might be who attributed no virtue Use of relics to relics, but considered them only as channels of virtue-as food or medicine which have in themselves no life and power, but are the means of life, nourishing and strengthening as though they were themselves a stay and support; while God is Himself the Author of life, in Whom we live and move and have our being. But what proof have we of relics being an appointed means of life and health ?-or what Scripture example could be taken as a precedent? Those instances, which seem most to the purpose, are far from authorising such a use of the dust of the dead, as that which prevailed in the Church for many centuries.

With the honour given to their remains, there Jesus the was associated the honour done to the Saints on tor and saviour. themselves. In their departed state, they were believed to be actively engaged in assisting their brethren and friends left behind on earth. We are told that Germanus sought in prayer the help 
CHAP. x. of the Blessed Alban; and through him he offered his thanks to God. It is only too evident that the worship and reverence due to the Saviour were being transferred to the Saints. At this early period the merits of the Saints were fast becoming that treasure which we have in Jesus, through Whom alone we present our petitions; there being none other Name under Heaven, given among men, through whom we can be saved. On the question of Merit, we have the teaching of the Eleventh Article of Religion.

Vision of Laurentius.

Visions also became a feature in the Church. Two examples may be given, which occurred at the beginning of the seventh century in the Anglo-Saxon Church, when Laurentius was Archbishop of Canterbury. He was about to leave the country in despair, on account of a general relapse of the King and people into their old idolatry and superstition. But whilst Laurentius was in the Church of the Apostles Peter and Paul, in Canterbury, in the dead of night, praying and weeping because of the unhappy state of the Church, there appeared to him the most Blessed Prince of the Apostles, who laid on him with a scourge, and asked why he would leave the flock intrusted to him-or to whom he would leave the sheep of Christ, now in the midst of wolves? "Art thou unmindful of my example, who 
endured chains, scourges, prisons, aftlictions, and Сн.г. $x$. finally death itself-even the death of the Crossfor the little ones whom Christ had commended to my care, that He might prove my love?-all which I endured at the hand of the enemy, that I might be crowned with Him." In the morning the King was shown the stripes, and was told that they had been inflicted because he and his people had despised the grace of God, and the gift of eternal life. The King was in great fear, at once returned to the true faith, and furthered by every means the work of the Church in lis kingdom.

Another vision was that of Edwin, who had Edwin and been driven from his kingdom of Northumbria, and had found a refuge with Redwald, King of Between the East Angles. The usurper sought, if possible, ${ }^{A}$.D. to accomplish Edwin's death. He offered Redwald money and other inducements to deliver him up. At length Redwald consented; but of this Edwin was warned by a faithful friend, who entered his bedroom at the beginning of the night, called him outside, and showed him the danger' he was in; adding, "If thou art willing, I will lead thee from this province into a place where neither thy enemy nor Redwald will be able to find thee." He replied, "I am thankful for thy kindness, but cannot do as thou dost suggest, for I shall give my friend real ground of offence, and 
chap. $x$. he has never yet failed in his friendship to me. And whither shall I flee to avoid the snares of my enemy?" His friend then left him alone in front of the palace, sad, and pondering what he should do, or whither he should turn.

While in this mood, a person of strange countenance and dress appeared to him. The stranger drew near, saluted him, and asked why, at that hour, he sat alone, sad and anxious. Edwin asked what it mattered to him how and where he passed the night. The stranger answered, "Do not suppose I am ignorant of thy condition. I know who thou art, and why thou art sad and troubled. But tell me what thou wouldst give the man that would free thee from thy fears, and persuade Redwald to do thee no ill, nor deliver thee up." He said he would do all in his power. "And what if he should make thee a king more glorious and powerful than all the kings of the Angles before thee?" He answered he would give real and worthy tokens of his gratitude. "And what if he should show thee a way of life better, happier, and more profitable than thy parents and relatives ever walked in? Wouldst thou consent to obey his wholesome counsel?" Edwin answered, without hesitation, that he would follow his teaching. The strange visitor then laid his hand on Edwin's head, and said, "When this sign shall be repeated, 
remember this occasion, this conversation, and do cHap. $\mathrm{x}$. as thou hast now promised." Then he suddenly disappeared.

Edwin still sat where he was, rejoicing, yet Hopes of a afraid, and wondering who the stranger was, and whence he came. While he was thus musing, the friend who had advised him to flee returned, and bade him rise, come in, and rest, for the king's heart was changed towards him. He had been recalled from his evil purpose, and was now convinced that good faith is of more value than the most costly presents.

In short, Redwald was determined to reinstate The vision fultilled. Edwin in his kingdom, and drive out the usurper. A.D. $^{\circ} 617$. He raised a large army, and succeeded in completely overthrowing the enemy of the youthful Edwin, who not only recovered his dominions, but greatly extended them. Two-thirds of the vision had now been fulfilled in his deliverance and restoration ; but yet the faith of Christ, which he had heard from the lips of Paulinus, the first Bishop of York, he hesitated to accept. Coming into his presence, a certain day, Paulinus laid his hand on Edwin's head, and asked whether he recognised the sign, saying, "Lo, thou hast escaped thy enemies; thou hast received back thy kingdom by the Divine favour and goodness; remember now the third thing which thou pro- 
CHLIP. $\mathrm{x}$. misedst, and do not hesitate or delay to welcome the faith and the teaching of Him Who has delivered thee from temporal evils, and has raised thee to the dignity of a temporal throne. If thou wilt obey His Will, which He delivers by my mouth, He will save thee from eternal evils, and make thee partaker with Himself of the everlasting kingdom in Heaven."

Edwin accepts the faith.
The King, recognising the sign, and hearing the words of Paulinus, confessed his duty and his readiness to receive the faith; but would first consult his princes and counsellors, and see if they agreed with him; if they did, they would together consecrate themselves to Christ in Baptism. 


\section{CHAPTER XI.}

NORTHUMBRIAN KINGS.

As he had promised Paulinus, Edwin, the king King of Northumbria, called a council of his council: chiefs and nobles, and inquired of them separ- $\begin{gathered}\text { speech of the } \\ \text { Paganh high }\end{gathered}$ ately their opinion of the new faith. The first to answer was Coifi, the high priest of Paganism. He said, "Whatever the new faith may be, the old has proved of no value or utility. No one has been more devoted to it than I, and yet no one has been worse served. If our gods can do anything, surely they ought to assist the man who has been most diligent in serving them. Whence it follows that if, upon trial, we find the new faith more to our advantage, we ought at once to receive it."

After him rose one of Edwin's chiefs, who speech of assented to the words of Coifi, adding, "The chief. present life, for shortness and uncertainty, may be compared to thee, $\mathrm{O}$ King, when sitting at supper with thy chiefs and servants, on a winter night. The fire is burning on the hearth, and 
CHAP. xI. spreading its warmth throughout the room; the winds and storms are beating outside; and there swiftly flies through the room a sparrow, entering by one opening, and disappearing at another. Whilst within it escapes the storm, but its comfort is only for a moment. It passes out quickly from winter into winter, from darkmess into darkness again. So with respect to the present life; what follows and what precedes we know not. If the new faith will teach us anything certain, it ought to be received with welcome.

Idolatry restroyed in Northumbria.
Coifi rose again, and asked that they might hear Paulinus. And having heard him, he exclaimed, "I knew the gods we worshipped were nothing; for the more diligently I sought the truth, the less I found it. Now I see it in this preaching, which promises salvation and happiness for ever. Wherefore I propose that the temples and altars we have consecrated in vain, be given to the curse and to the fire." To this the King agreed. The faith of Christ was confessed, and idolatry was renounced. When it was asked, who would be the first to throw down the idolatrous shrines, Coifi answered, "I will; who is fitter than I, who have been the leader in folly?" He, whose office had forbidden him to mount a horse or hold a lance, rode off, lance in hand, to destroy the idols 
of Northumbria, to the joy and wonder of all CHAP. xı. beholders.

At the following Easter, 12th April, 627, Ed- Baptism of win was baptized in the Cathedral Church of his family, York, which the King had hastily erected of wood-a structure which finally developed into the present magnificent Minster. For six years longer Paulinus preached the Word of the Lord in the kingdom of Northumbria, until the death of Edwin. Among those who believed, and were baptized, were two of Edwin's children by a former marriage, and three by his second marriage with the daughter of Ethelbert and Bertha, the King and Queen of Kent.

From Northumbria Paulinus visited the king- spread of dom of the East Angles, extending from the in East Humber to the Thames. Redwald, the King Anglia.

like the Samaritans of old, was half Christian and half heathen - worshipping one day with the Christians, the next in the idol temple. His kingdom consequently drifted back into idolatry, until the accession of Sebert, who had been exiled in France. On his return to take Ahout A.D. 628 . possession of his throne, he brought with him, from Burgundy, Bishop Felix, to evangelise his people. The labours of Felix were greatly blessed. The whole province returned to the faith, and to those good works which are the fruits of faith. 
CHap. xI. Paulinus also was labouring in the extension of the knowledge of Christ, and in the erection of a Cathedral Church at Lincoln, which became almost the counterpart of the Minster at York. The See of York had been left in charge of his faithful deacon, James. Such good results followed the labours of these earnest Christian missionaries, in the north and east of England, that it was said a mother might travel with her little boy the country through, from sea to sea, without fear of harm.

Edwin's death.

Civilisation, and a more regular administration A.D. 633 . of justice, followed in the wake of Christianity. Edwin raised drinking fountains on the roads, wherever good springs of water were found. $\mathrm{He}$ made state processions through his dominions on horseback, attended by his ministers, and preceded by a standard-bearer, for the punishment of evil-doers, and the encouragement of them that did well. After a reign of seventeen years, the last six of which he had fought under the banner of Christ, he was slain A.D. 633, in a great battle with Cadwalla, a British King, and Penda, King of the Mercians. The immediate consequence of his death was a massacre of Northumbrians, and a restoration of Paganism. Penda was thoroughly devoted to idolatry; and Cadwalla was Christian in name, but 
a stranger in heart and life to every Christian CHAP. XI. principle.

At this period, Britain was in possession of Differences the old inhabitants, the Britons, and of the recent $\begin{gathered}\text { betwitish } \\ \text { and } \\ \text { and An }\end{gathered}$ invaders, the Saxons and Angles. The Britons $\begin{gathered}\text { and axon } \\ \text { Churches. }\end{gathered}$ had been driven into the west; the Saxons and Angles held the north, east, and south. There was a Christian Church among the Britons, long before the arrival of the Anglo-Saxons, who were Pagan idolaters, until the mission of Augustine in A.D. 596. There were, therefore, not only two bitterly hostile races, but two bitterly hostile Churches; differing in their order and discipline, especially as to the time of observing the feast of Easter, and equally tenacious of their own peculiar customs. The British Christians counted the Christianity planted by Augustine among the Anglo-Saxons, as nought; and would sooner have communicated with the Pagans than with the Christian Saxons. These latter called the British Christians ignorant and stubborn, unlike all other Christians in the world. Proposals came from the Saxon Church some time after it had been established, asking that the old and new Churches should amalgamate, but on the condition that the old Church should be subordinate to the new. In the many conflicts between Britons and Saxons, there was always a 
снар. хI. large element of religious strife and intolerance.

Eanfrid and Oswald sueceed Edwin.

The kingdom of Northumbria consisted of two provinces: the one in the south, named Deira, reached from the Humber to the Tyne; the other in the north, named Bernicia, reached A.D. 633. from the Tyne to the Clyde. Eanfrid, the son of Ethelfrith, returned from exile among the Picts and Scots after the death of Edwin; ruled for a short time over Northumbria; and was then slain in an engagement with Cadwalla and A.D. 635. Penda. He was succeeded by his brother Oswald, so remarkable in the history of the early Saxon Church, and afterwards known as St. Oswald, after whom many English Churches have been named.

Oswald's victory near Hexham.
The Picts and Scots had been evangelised some time before Oswald and his brother had been exiled amongst them. From them Oswald himself had received the Gospel, and became an earnest and sincere convert. He gathered the remains of his brother's army, led them against the enemy in the Name of the Lord, and gained the victory in the great battle near Hexham, where Cadwalla was slain. The battle-field was long held in veneration. It was a victory of Christians over Paganism. Before the battle, Oswald, on bended knees, besonght the Lord to 
give him help. He addressed his whole arniy chsp.xı. thus with a loud voice: "Let us kneel and pray to the Almighty, the living and true God, to defend us from our proud and fierce enemy; for He knows we have undertaken this war for the safety of our nation." After prayer, the battle began at early dawn; and faith and prayer won the day.

An institution sprang up early in the Church, Institution of great advantage in certain conditions of society, teries. but liable at other times to become a snare and a delusion-namely, the isolation of Christian men and women in monasteries and numneries-there to live separated from the world, and from all their natural guardians, by rules which regulate their whole life, and the application of their whole time night and day. Christians who lived this monastic life were named Regular, and were distinguished from Christians, who mingled with the world, and were named Secular. The monastic life led to a celibate or unmarried clergy, which was affirmed to be a holier estate than marriage; and had for its outward and visible sign the tonsure, or shaving of the crown of the head.

In a feeble and insecure state of society, Aidin Christians needed certain well-established and Bindisfium of strongly-organised centres of life and work. There was a celebrated monastery in the island 
CIAPP. xi. of Iona, off the west of Scotland, which will illustrate the distinguished services which such institutions rendered. After Oswald was securely seated on his throne of Northumbria, he sent to the Scots, among whom he had been exiled, requesting them to send him a Bishop, to reestablish the faith in his dominions. He had not long to wait. They sent him Aidan, a man of fervent piety, of great judgment and courtesy, whose Christianity was more of the British than of the Anglo-Saxon type. Oswald assigned him the island of Lindisfarne, afterwards called Holy Island, near the coast of Northumberland. The King assisted him in every way in his work. He translated to his assembled chiefs, ministers, and people what Aidan preached. Converts increased; churches were built; the people flocked together to hear the Word of God; lands were granted by the King, and monasteries were built, to which the Anglo-Saxon youth were sent for knowledge and discipline. Monks were employed by Aidan, himself a monk from Iona, which was long the headquarters of the monastic institutions of Britain.

Monastery of Iona.

The Monastery of Iona was founded by Columba, who had crossed the Grampian Mountains to preach the Gospel to the northern Picts. The southern Picts had been converted by the 
preaching of St. Ninyan, Bishop of Whithorn, chap. xı. in Wigtownshire; whence the See was afterwards removed to Glasgow. After much success among the northern Picts, their King gave Columba the island of Iona for the establishment of a monastery. Before coming to scotland, he had founded a noble monastery in Ireland, the parent of many others; but over them all Iona was made supreme. The heads, or Abbots, were priests, but never Bishops. Over all monastic institutions their authority was higher than that of the Bishop, which was often a cause of much strife within the Church.

It was from the Monastery of Iona that Aidan Aidan's came to evangelise the kingdom of Oswald. His life was in harmony with his doctrine. He was unmindful of this world, its wealth, and its honours. He bestowed on the poor all his goods. Every one whom he met in the street, or on the road, was invited by him to share in the blessings of the Gospel ; if he were a believer already, he was encouraged to greater diligence in the race for the prize of our high calling. He enjoined upon his followers a fast on Wednesdays and Fridays, until the ninth hour.

Another of the Iona brethren had been sent $\begin{gathered}\text { Cause of } \\ \text { Aidan's }\end{gathered}$ before Aidan, in answer to Oswald's application ; election a man of a more austere disposition, whose mis- Bishopric of 
CHAP. XI. sion was attended with so little success, that he returned to his monastery, and reported that the people of Northumbria were of a hard and intractable nature. The elder monks met in council, and amongst them was Aidan, who thus addressed the unsuccessful missionary:"Brother, it seems to me you have been too severe. You have not acted according to the Apostolic maxim, ministering first the milk, and then the strong meat." The Council then proceeded to discuss what should be done to meet the needs of the King of Northumbria. It was finally decided to send Aidan, through whose earnest preaching the people of Northumbria were blessed with the hope of eternal joys, and, at the same time, with earthly greatness and prosperity beyond any previous experience.

Charity and humility of Oswald.
Notwithstanding the glory of his reign, Oswald was a man of great humility and kindness towards his poorest subjects. On one occasion, being seated at dinner, there was before him a silver dish, filled with royal dainties. As soon as the blessing had been pronounced, a servant entered, saying that there was a crowd of poor asking his Majesty's alms. Oswald ordered both the dish and its contents to be taken away, and divided amongst them. Aidan, who was seater near the King, seized him by 
Northumbrian Kings. $\quad 117$

the right hand, and blessed him; saying- chap. xı. "May this hand never grow old." Afterwards, when he had fallen in battle, and his hands and arms had been severed from his body, they were preserved in a silver chest in the Cathedral of York, and, it was said, undecayed and uncorrupted. 


\section{CHAPTEP XII.}

THE EASTER CONTROVERSY.

Political and religious progress in England.

THE portion of Britain possessed by the AngloSaxons was divided into seven kingdoms, forming altogether what has been called the Heptarchythe chief or leading kingdom being at one time Northumbria ; at another East-Anglia ; at another Kent; at another Wessex; at another Mercia or Mid-Anglia. Anglo-Saxon Christianity spread from Kent; British Christianity from the Monastery of Iona; and the two streams met in Northumbria. Paulinus, King Edwin's missionary, came from the south ; Aidan, King Oswald's missionary, came from the north. Finan and Colman, who succeeded Aidan in the Bishopric of Holy Island, came likewise from the north. Penda, King of Mercia, was the zealous patron of the old Saxon idolatry. His name was a terror to all his neighbours. He had slain King Edwin in battle, in an invasion of Northumbria. In another invasion, A.D. 642 , he fought the great battle of Maserfield, in which King Oswald fell. 
The sanctity of this illustrious prince was cins. XII. magnified to a marvellous degree by the miracles The piety which were reputed to have been wrought by Oswald. him, and by his ashes and other relics. As he had bestowed alms in abundance during his life, his corpse after death was equally powerful for good. It prevailed against fire; a heavenly light hovered over it one whole night; evil spirits were cast out, and fevers allayed by it. His head and arms, on which Aidan had pronounced the blessing, "May they never grow old," were transferred to the Cathedral Church of Holy Island. His relics were distributed far and wide. In Ireland, during a time of plague, a person of distinguished learning, but regardless of his salvation, fell ill, became alarmed about his soul, and with trembling lips cried out that he was lost, and that, if he should die, he must be eternally lost. He resolved, if he were spared to live longer, to give himself wholly to God. But this new lease he could not hope to obtain without the pardon of his sins, which could only come to him through the merit of one who had served God faithfully. The sick man had heard of the holy King Oswald, and of the virtue which had issued from his body; and, remembering that he had in his possession a relic from him, he believed that, with firm faith, it might be the 
CHAP. xIr. instrument of his recovery. And it is said to have been the cause of his immediate restoration to health; and, according to his vow, he lived henceforth to God, preaching everywhere the mercy of the gracious Creator, and the glory of his faithful servant Oswald. So much was the truth, as it is in Jesus, overlaid by the ignorance. and superstition of the age !

Aidan's prediction, A.D. 651 .

Oswald's friend, Aidan, entered into his rest A.D. 651. Like Oswald, he was considered worthy of a place among canonised Saints, on the ground both of miracles and prophecy. The following instance of a prophecy is recorded by the Venerable Bede. The prophecy might in reality be a conclusion, drawn from observation and superior intelligence, in interpreting the facts of nature. A presbyter, in high esteem with the Kings of Northumbria, was sent to fetch Eanfleda, daughter of King Edwin, from Kent, whither she had fled for safety, after her father's death, to be the wife of Oswy, who had succeeded his brother Oswald on the Northumbrian throne. The presbyter intended to go by land and return by sea, but first went to Aidan to ask his blessing on the journey. After blessing and commending him to God, he gave him oil, which he had consecrated, saying, "I know that, as soon as you are on board and have set sail, a storm will overtake 
you; but remember to pour this oil on the chap. XII. troubled waters, and the winds will be hushed and the sea calm, and you shall come back in safety." All, it is said, came to pass, as Aidan predicted.

Aidan died in a tent, which he had erected Death and against the west wall of his church, near the clidan. royal city of Bamborough, Oswy's capital, and his body was laid in the Cathedral of Holy Island. He is described as a man of peace and charity, of humility and self-denial; unmoved by anger, avarice, pride, or vainglory; industrious in observing every Divine precept, in reproving the great and powerful, in assisting and consoling the poor and needy ; careful, to the utmost of his power, to observe whatever he had learnt from the prophets and evangelists.

Finan succeeded Aidan as Bishop of Lindis- King Oswy farne, and after him Colman. Like Aidan, they intluencer were both from the Monastery of Iona, and trained in the discipline of British Christianity. Oswy was now King of Northumbria, and harl been educated and baptized according to the rites of the British Church; whereas his son, Alchfrid, had for his tutor the learned Wilfrid, whose rules of religion were those of the Anglo-Saxons and of Rome. Wilfrid was invited into Northumbria at the instance of Alchfrid; and land was granted 
CHAP. XIr. him for a monastery at Ripon-land which had been already assigned to the monks of Iona, but, upon their refusal to conform to the Anglo-Saxon ritual, it was taken from them and given to Wilfrid.

The Easter controversy.

A.D. 661 .

It was at this time that the question of Easter was agitating the Churches of Britain. British Christians observed the Sunday, which falls on or after the fourteenth day of the Passover moon. The Anglo-Saxons observed the Sunday which falls on or after the fiftecnth day of the Passover moon-the moon which comes to the full on or next after the twenty-first day of March. It was King Oswy's determination to settle the point once for all by the decrees of a Council, which was held in the monastery of the Abbess Hilda at Streneshalc, over which the King presided. Both sides were represented by their leading men. On the British side were the King, Bishop Colman, the Abbess Hilda, and Bishop Chad. On the Anglo-Saxon side were Alchfrid, the King's son; Agilbert, Bishop of the West Saxons; Wilfrid, and James the Deacon, the friend and coadjutor of Paulinus.

The speeches of the King and Bishop Colman.
The King first delivered a short address, to the effect that those who serve One God should keep to one rule, in their administration of the Sacraments and other ordinances, since all expect to 
meet in one home in Heaven. All ought to ascer- cHap. xII. tain the correct tradition, and follow it. $\mathrm{He}$ called upon Colman to speak, as the representative of British Christians, and say what his custom was, and what its origin. Colman rose and answered: "The Easter which I observe was that of the fathers of Iona, who sent me hither, and ought not to be set aside, since it was the custom of the Apostle and Evangelist John, the beloved of Christ, and of the Churches over which he presided." The King next called upon Agilbert to say what his custom was. As one who had not long resided in England, and must speak by an interpreter, he desired that Wilfrid, with whom he agreed, might be requested to speak for the Anglo-Saxons.

At the royal command Wilfrid rose and said: wilfrir "The Easter which we observe is that of the replies to Blessed Apostles Peter and Paul, who lived, taught, suffered, and died at Rome. Their custom is observed in all parts of the world, save only among these obstinate Britons, who are engaged in a foolish contest with all other Churches in Asia, Africa, Europe, and in the greater part of Britain itself." Colman replied, "Do you call that foolish which we do after the example of him who leaned on the breast of the Lord?" Wilfrid answered: "Far be it that I should blame 
chap. XII. John, who observed the letter of the law, while the Church was yet in many respects Jewish, nor yet able to break away from Jewish ordinances. The Apostles desired to avoid giving offence to the Jews who lived among the Gentiles: and therefore Paul circumcised Timothy; offered sacrifice in the Temple for his own purification; had his head shorn at Cenchrea to signify the expiration of a vow. And John for the same reason observed the fourteenth day of the Passover moon, and began the celebration of the Easter festival on the eve of that day, being the time when the Passover feast began, whether the day was a Sunday or not.

"But Peter kept in mind that the Lord rose from the dead on the Sunday, being the first day of the week, and consequently waited until the Sunday next after the fourteenth day; which night be the fifteenth, or any day up to the twenty-first; and then began the feast of the Resurrection. In this way he observed the law and the custom of the universal Church, as it was afterwards confirmed by the Council of Nicea. But you follow neither John, nor Peter, nor the law, nor the Gospel. You do not follow John, who began the Easter festival when the Jews began the Passover; but wait until the Sunday on or following the fourteenth of the moon. You 
do not follow Peter, who began on the Sunday, ch.s. xir. not on, but following the fourteenth; which might be the fifteenth, up to the twenty-first. You do not follow the law, for what you call the fourteenth is the thirteenth of the moon; and you do not follow the Gospel, for our Blessed Saviour observed the Passover, and instituted His holy Supper on the evening which began their fourteenth day, and was the eve of our fifteenth."

Colman then referred to Anatolius, Bishop of Arguncuts Laodicea, a great authority on the question; and and Wilfrid. to the practice of Columba, the founder of the great Monastery of Iona. Wilfrid replied that Anatolius availed them nothing, for his rule they did not follow, and as for Columba, he knew nothing of him, adding, "Many will say at the day of judgment, 'Lord, Lord, have we not prophesied in Thy Name, and in Thy Name cast out (levils, and in Thy Name done many wonderful works?' to whom He will answer, 'I never lnew you.' Not that I think this of your fathers. On the contrary, I think and believe they served God with rustic simplicity, but with pious intention, and their keeping of Easter on the Sunday which may fall on the fourteenth to the twentieth, instead of on the fifteenth to the twenty-first, was through want of better information. But nuw 
CHAP. xIr. you have that better information, and yet you persist in your opposition to the whole world, and set up your Columba as an authority against the most Blessed Prince of Apostles, to whom the Lord said, 'Thou art Peter, and upon this rock I will build my Church, and the gates of hell shall not prevail against it; and I will give to thee the keys of the kingdom of heaven." "

Further arguments of Colman and Wilfrid.

At this point the King intervened, and asked Colman if he admitted these words to have been spoken to Peter. "Certainly, O King," answered Colman. "But," asked the King, "was this authority given to your Columba?" “No," answered Colman. Again the King asked, "Do each of you agree that these words were first addressed to Peter, and that the keys of the kingdom of heaven were given to him?" "Even so," they answered from both sides. Then said the King, "Since this man is the doorkeeper, I am unwilling to oppose him; rather do I to the fullest extent desire to obey his ordinances, lest perchance when I come to the door of the kingdom of heaven there may be no one to open, he having turned from me who is proved to have the keys."

The King pronounces

When the King had thus concluded, the judgment. majority of the Council voted for the adoption of the lioman custom, and the British was 
thenceforth given up. Colnman relinquished his chap. xII. See of Lindisfarne, and returned to Iona; and there succeeded him one who followed the Roman rule, though of the British Church. Chad of Lichfield and the Abbess Hilda also went over to the Roman side.

We have here an illustration of the growing the Roman influence of the Roman Church, and of the argurule prevails. ments used for the increase and confirmation of that influence throughout the world. For many centuries no argument prevailed so much in deciding religious questions in favour of liome as that Peter taught at Rome, was the rock on which the Church was built, and possessed the keys of the kingdom of heaven. 


\section{CHAPTER XIII.}

\section{GENERAL COUNCILS.}

The hypo-
static union. The most important subject upon which the C'hurch has been divided is the Nature and Person of her Lord. The mysterious union of the Divine and human natures in the Person of Christ must ever be beyond the most perfect understanding. The utmost we can do is with meekness to receive the statements of Holy Scripture, and, with the help of the Holy Spirit, derive such needful light and comfort in our minds as they are intended to convey, and we are capable of receiving.

The six

General Councils.

In the early ages of the Church there was much speculation by the heretics, especially upon these high mysteries. Heathen philosophy mingled with the doctrines of Holy Scripture, widely differing views were held of the person and work of the Redeemer, and much disturbance and division were caused in the Church. The troubles were met in the best way the circumstances of the time would allow. The authority 
referred to in the first instance for the settling CHAP. xIIr. of disputes was the Bishop. Then there was an appeal to a Synod of Bishops and clergy, and afterwards to a larger Synod or Council; and finally, when the world came under the rule of one man, and after he had become Christian, a Council, called Ecumenical, representing the Catholic or universal Church, was summoned by him. The first of these was summoned by Constantine the Great in 325 , the second by Theodosius in 381, the third by Theodosius the Younger in 431, the fourth by Marcian in 451 , the fifth by Justinian in 553, the sixth by Constantine Pogonatus in 681. Since these six, no other General Council has been acknowledged by the universal Church.

The chief purpose of these assemblies was to The settling settle controversies, and to decide upon the teach- sies. ing of Holy Scripture with respect to disputed points of the mystery of Christ and of the Holy Spirit. Arius, who denied Christ's Divine nature, was condemned by the first; Macedionius, who denied the Divinity of the Holy Spirit, was condemned by the second; by the third, Nestorius was condemned, who denied a perfect union of the Divine and human natures in one person, at Christ's conception by the Holy Spirit; by the fourth Eutyches was condemned, who denied that the two natures remained distinct after the 
CHap. XIIr. Incarnation; the fifth confirmed the decisions of the first four; and the sixth condemned Theodorus, who maintained that in Christ the human will was lost in the Divine. The followers of Eutyches were named Monophysites; those of Theodorus, Monothelites.

The title

"Mother of God ;" the heresy of Nestorius.

While condemning error, the General Councils defined, as clearly as human language and human understanding could, the doctrine of the Trinity according to the Word of God. Nestorius objected to a title given to the Virgin, which had become common in the Church, namely, "Mother of God." By this title it was intended to affirm not so much the honour of the Virgin as the Divinity of her Son; and that He Who was conceived by the Holy Ghost and born of the Virgin Mary was the God-man, truly and distinctly God and man-One Christ, Who suffered, died, was buried, rose again, and now sits at the right hand of God. St. Paul affirmed no less when he thus addressed the elders of the Church at Ephesus: "Take heed to the flock, over which the Holy Ghost hath made you overseers, to feed the Church of God, which He hath purchased with His own blood." Nestorius held that the union of God and man in Christ was but one of friendship and respect, whereas the Church held it to be real, substantial, and never to be divided. It 
was to maintain the Oneness of Christ, and at the chap. xIII. same time the distinct existence in Him of the two natures, that the third General Council met at Ephesus, under the presidency of Cyril, the Bishop of Alexandria.

But, although condemned and deprived of his The Nesposition as Patriarch of Constantinople, Nestorius persisted in his errors, which spread rapidly over great part of the East. They were zealously propagated by the Church of Edessa, and took firm root in Persia. There was a Nestorian Patriarch at Seleucia. The Nestorian missionaries laboured successfully in Armenia, Chaldea, Syria, Arabia, India, and Scythia. In the 13th century they had bishops and clergy among the Chinese, and in several of these countries Nestorian churches are to be found at the present time.

In twenty years from the Council of Ephesus The heresy it was found necessary to summon another, which met at Chalcedon. In his zeal against Nestorius, Eutyches, the Abbot of Constantinople, fell into the opposite error. The Council of Ephesus had affirmed the oneness of Christ's person. This Eutyches understood to be an affirmation of the oneness of His nature, and that by the Incarnation the human was wholly absorbed by the Divine. The Athanasian Creed was held to favour Eutyches in the following words: "As soul and 
chap. xirr. body become one man, so God and man become one Christ." Eutyches argued: "If this be true, and if one man has but one nature, though consisting of soul and body, Christ can have but one nature, though being both God and man." He pressed the comparison of the Creed too far. Things which we compare are seldom comparable all round; the analogy may hold but in a very few points. It was declared by the Council, by which he was condemned, that whilst in Christ there is but one Person, there are the two distinct natures of God and man; "neither confounding the substance," like Eutyches, " nor dividing the person," like Nestorius.

The

Eutychians or Monophysites.

The error of Eutyches spread, like that of Nestorius, over Edessa, of which the Bishop was Jacob, who became the head of a sect named Jacobites. The heresy spread over Syria, Mesopotamia, Egypt, and Abyssinia. At present there are three principal sects-Oriental, African, and Armenian.

The Monothelites.

Another question respecting the mystery of Christ agitated the Church of the seventh century. Theodorus, Bishop of Mopsuestia, with whom Honorius, Bishop of Rome, sympathised, thought that there was but one will in Christ, and that the human will was lost in the Divine. He grounded his doctrine upon the words of the Lord, in the 
garden of Gethsemane, when in His agony He chap. xıII. prayed, "Nevertheless, not my will, but Thine be done." But what do we really find? While the Divine Will was that Christ should suffer, the human will desired that the cup of suffering should pass from Him. The human will shrank from suffering, but was submissive; while the Divine Will ordained it, as the remedy for the suffering and death of mankind. The Sixth General Council, which met at Constantinople, decreed that, as the two natures are in Christ, so there are in Him two distinct wills, human and Divine.

The decrees of these six Councils are the voice the of the Church echoing the voice of Holy Scripture, anthority and are binding on us now, not because the Councils decreed them, but because, as the Church has always acknowledged, they are the teaching of the inspired Word.

Preparations for these great Councils were Preparation usually made by smaller Councils, or Synods of for a General the several national Churches. For example, before the Sixth General Council, a Synod was a.v. bso. held at Hatfield of the English Church, under the presidency of Theodore, Archbishop of Canterbury. Here representatives were elected to be a deputation to a larger Council at Rome, under the Bishop there. Wilfred was the 
chap.xiIr. chosen English representative. Then again, at Rome, representatives were chosen from the members of the Council, who proceeded to the Great Council of the whole Church of the East and the West.

The Council

The English Synod embodied its conclusions in of Hatfield. the form of a letter, addressed to the clergy and Church of England. It proceeds thus: "As our Incarnate Lord, Jesus Christ, delivered to His disciples, who saw Him in the flesh, and heard His discourses; so have all holy and Catholic Synods, and the whole band of approved doctors of the whole Church, delivered the doctrine of our holy fathers. And we, following them devoutly and correctly, profess our agreement with their divinely inspired doctrine, and confess with our holy fathers, sincerely and truly, the Father, Son, and Holy Spirit; One God in Three Persons; of the same substance, and of equal glory and honour. We also have accepted the five General Councils of our holy fathers, namely, those which, to the number of 318 , met in Nicea against Arius and his teaching; in Constantinople, to the number of 150, against Macedonius and his doctrine; in Ephesus, to the number of 200, against Nestorius and his doctrine; in Chalcedon, to the number of 630, against Eutyches and Nestorius; and in Constantinople, against Theodorus and the doc- 
trine which he taught, in opposition to Cyril. chap. xirI. And we glorify our Lord Jesus, as they glorified Him, without adding to, or taking away; and we anathematise whom they anathematised; and whom they received we receive, glorifying God the Father, without beginning; and His only begotten Son, begotten of the Father before the worlds; and the Holy Spirit, proceeding from the Father and the Son, after a manner which no pen can describe, nor tongue utter; as apostles, prophets, and doctors have taught and preached; and we have all put our hands to the Catholic Faith, as it has been by them and us expounded."

Theodore, who presided over the Council of Theodore Hatfield, was the seventh Archbishop of Canter- made Arch bury after Augustine. His appointment will furCanterbury. ther illustrate the growing power and influence of Rome, especially over the Western Churches of Christendom. The See of Rome looked upon the Anglo-Saxon Church, planted by Augustine, as a daughter, over whom she might and would exercise the rights of a mother. On the death of Theodore's predecessor, the Kings of Kent and Northumbria agreed upon a candidate, whom they sent to Rome for consecration. But he and his companions died of the plague soon after they arrived there. Without any apparent reference 
Chap. xir. to England or her kings, the Bishop of Rome looked about for a successor in the monasteries of Rome. The Pope thought of the Abbot Hadrian, but he objected on the ground of unworthiness. When pressed, he begged that he might name another. This was Theodore, a native of Tarsus, in Cilicia. He was sixty-six years of age, and well versed in sacred and profane literature. Theodore was accepted, on the condition that Hadrian accompanied him, as being acquainted with the countries through which they had to pass; and likewise to prevent Theodore, who was a Greek, and of the Eastern Church, from falling into any doctrine or discipline at variance with the Roman Church.

Theodore's administration.

He was consecrated by Pope Vitalian in the year 668, and after a protracted journey, in company with Hadrian, arrived in England, to govern a Church to which both were strangers. Hadrian became head of the Monastery of St. Peter (now St. Augustine's) Canterbury; while Theodore entered upon a general visitation of the Church. He was the first Archbishop who brought all the Churches of England into one communion. He took great pains to promote learning, especially among his clergy. He communicated so thorough a knowledge of Latin and Greek, that they were said to have been as familiar to his scholars as their 
native tongue. Times were never more peaceful chap. xirl. and prosperous in Britain, the kings never so powerful, their subjects, like themselves, having their minds set upon the duties and the joys of religion.

In the year 673 , Theodore presided over the synod of Synod of Hertford. There were present the Hertford. Bishop of East Anglia; Wilfrid, now Bishop of Northumbria; the Bishops of Rochester, of Essex, and of Mercia, with their leading presbyters. The Archbishop opened with an address as follows :-_" I, Theodore, appointed by the Apostolic See, although unworthy, Archbishop of Canterbury, and my most reverend brethren here present, beseech you, for the love of our Redeemer, to consider together our common faith, and to see that the decrees which have been delivered to us by our holy and approved fathers be preserved by us incorrupt, for the furtherance of all things which appertain to the peace and unity of the Church. I ask all present to signify their assent to the decrees, and to the faith, as anciently and canonically delivered." This all did with readiness.

Then he presented for their approval and assent canons of the following Canons:-(1) That all observe the Hertford. Easter festival on the Sunday next after the fourteenth day of the Paschal Moon; (2) That each 
снлр. хиI. Bishop confine himself as Bishop to his own diocese; (3) That no Bishop interfere with any monastery, or with the property belonging thereto; (4) That monks shall not pass from one monastery to another without the permission of their superior; (5) That no clergyman pass from one diocese to another without letters of commendation from the Bishop of the one to the Bishop of the other; (6) That Bishops and clergy be content with the hospitality provided for them, and that they perform no religious service in public without permission of the Bishop of the diocese in which they may be; (7) That a Synod be called twice in the year, and once a year a more General Synod of the whole English Church, in the month of August; (8) That no one Bishop exalt himself above another; (9) That the number of Bishops be increased with the increase of the Church; (10) This canon related at considerable length to questions of morals.

A united

National

As illustrating the energy of Theodore, and the Church. strictness of his adherence to Roman rule, he required the reconsecration of one Bishop who had been consecrated by certain British Bishops, whom therefore he considered not duly consecrated. Such was his zeal in putting down the British Church, for the sake of establishing the AngloSaxon of Augustine as the sole Church in this 
land. Another Bishop he deposed for some act of снир. xiII. disobedience, although a man of correct doctrine and morals. But he succeeded in binding the Church together into one national Church, long before the nation was united under one sovereign. And there is good reason for believing that this union of the Church led to the union of the kingdom, which has since developed into the largest and most powerful of Empires. 


\section{CHAPTER XIV.}

ATTILA, KING OF THE HUNS.

Truth prevails in the end.
The pride of princes humbled.

THE power of true religion and of the Church of God has always in the end been more than a match against false religion, even when that false religion has been backed by the princes of this world, whether they have been cruel and coarse barbarians, or refined and well-educated Greeks. The waves of heathenism have often darkened the horizon of the Church of God, threatening it with an overwhelming storm; yet that Church has prevailed in the end, and the heathen have either submitted themselves, or have been destroyed.

At intervals the world's history presents us with examples of great and leading men building up an Empire. They have gone forward irresistibly from conquest to conquest. They have come to be regarded by themselves and their followers as invincible. But ere long they have been made conscious of the presence of One greater than themselves standing in their way, 
as the Angel stood in the way of Balaam, when CHAP. xIv. their purpose has been not to bless, but to curse His people.

Alexander the Great is an instance. He built Alexander an empire upon the ruins of the great Persian Empire which he had pulled down. He had fought his way victoriously from his kingdom of Macedon to the land of Israel. He sent a demand to the High Priest at Jerusalem by letter, that he must transfer his allegiance from the King of Persia to himself. The High Priest replied that he could not break his oath of allegiance to Darius. The mighty conqueror became very angry. He was then engaged with the siege of Tyre, the prince of merchant cities. He took it, and also Gaza; and the land of Israel was consequently between the finger and thumb of Alexander, who then proceeded to punish the High Priest.

At that time two brothers, Jaddua and Man- The Temple asseh, divided the office of High Priest between in Mrizzimt them. Manasseh married, against the law of the Jews, a foreign wife, daughter of Sanballat, the Persian Governor of Samaria. The Jews held that Manasseh was thus disqualified for his holy office, and they expelled him. His father-in-law, however, promised, if he would not put away his wife for the sake of keeping his office, he would, 
CHap. xiv. through his influence with the King of Persia, provide him with another temple, and make him the High Priest of it. But when the King of Persia was utterly routed in the battle of Issus, in Cilicia, Sanballat at once transferred his allegiance to the victorious Alexander. Moreover, he sent him assistance in men and money, with a letter, asking the favour which he had promised his son-in-law Manasseh. This was granted, and the temple was built on Mount Gerizzim, in opposition to that of Jerusalem; and Manasseh was made its first High Priest, in opposition to his brother Jaddua, who was in ill odour with Alexander. This was part of Jaddua's punishment for his refusing to break his word to the King of Persia, and the beginning of that bitterness between Jews and Samaritans of which Jesus tasted at Jacob's well.

Jarldua prepares to meet Alexanter.

Jaddua was in mortal fear of his enemy, who was now approaching; but was comforted by prayer and by a vision, in which he was instructed to go out in solemn procession with the priests in their robes, and with the people clad in white garments, to meet Alexander. The soldiers of the conqueror were eagerly expecting the speedy capture of the far-famed city and temple. They anticipated the possession of magnificent spoils. The people went forth dressed 
in white; the priests in their robes of fine linen; CHAP. xIv. the High Priest, with his noble bearing, in purple and scarlet, the mitre on his head, with its plate of gold, bearing the motto, "Holiness to the Lord."

Alexander, as he approached alone, bowed in slexanter adoration of that Holy Name, and was the first to Giod of salute. Then the priest and the people saluted. Israel. One of the generals of Alexander asked his master why he, whom all adored, adored this High Priest? The Prince replied, "I did not adore him, but that God, Who has honoured him with the office. I saw this very person, in this very dress, in a dream which I had in Macedonia, when I was considering with myself how I should obtain possession of Asia; and he exhorted me to make no delay, but boldly push on; that he would conduct my army, and give me the victory and dominion over the Persians. I believe that, under the Divine conduct, all will come to pass according to my dream." The High Priest then led Alexander into the city, where he offered sacrifices to the God of Israel. The High Priest also pointed out in the Book of the Prophet Daniel, the passages where he predicts the conquest of the Persians by the Greeks. On the following day Alexander departed, leaving the city unharmed, and promising freedom of wor- 
CHAP. xiv. ship to the Jews throughout his dominions. This is an instance of submission to the Name of the Lord and His worship at Jerusalem on the part of a refined and literary prince-the conqueror of the Persian and the founder of the Greek Empire-which occurred a little more than three centuries before the Birth of Christ.

Waves of population from the Fast.
Another instance of a victory gained over worldly power by the Church of God shall be that of another great conqueror-a rude, cruel, uncivilised, and uncouth barbarian-who contributed more than any one to the downfall of the Roman Empire, to the foundation of the feudalism of the Middle Ages, and the formation of the modern States of Europe. This instance occurred about the middle of the fifth century of the Christian era. That period was one of terrible political convulsions. When some huge rock is hurled into the sea, wave follows after wave, and beats violently against the neighbouring beach; so wave after wave of population swept over the countries of Europe from east to west, starting from some centre of disturbance in Asia. Reference has already been made to the invasions of Asia Minor, Thrace, Greece, and Italy by the Goths, and the sack of Rome by Alaric, their King, A.D. 410. But a wave of Huns swept behind that of the Goths, and with greater 
violence, under the leadership of the dreaded chap. xIv. Attila, whose boast it was that the grass never grew on the spot where his horse had trod.

The Emperor Valentinian III., whose Court Attili and was at Ravenna, had a sister named Honoria. Attila declared himself her lover and champion. But the proposals of the barbarian prince were rejected by the imperial Court; and at sixteen years of age Honoria, for the sake of her better security, was put in seclusion, where she passed some twelve to fourteen years in enforced religious duties. At length she made a desperate effort to gain her freedom. She determined to put herself in the hands of Attila. She sent by a faithful eunuch a ring, earnestly entreating him to claim his faithful spouse. These addresses were received with some disdain by one who had multiplied his wives at his own pleasure, and at his own time. But he decided to demand the release and surrender of his bride, with a fair share of imperial territory as her dowry. This was declined; and it was alleged that the hand of Honoria had been pledged to another. Immediately after the discovery of this connection between Attila and Honoria, she was married to an obscure individual, and confined within the walls of a prison. 
chap. xiv. Attila now pursued his revenge. All the cities

Attila's desolating march.
His unconquerable spirit. and countries, as he passed from Scythia in the East to Gaul in the West, were mercilessly ravaged and destroyed. Some few, like Troyes, in France, were saved, as it was believed, by the prayers, or the merits, or the miracles of Saints. Metz was taken by storm. There was one promiscuous massacre of priests at the altar, and of helpless infants, who had been brought with haste, in the hour of danger, for Baptism. Finally the whole city was given to the flames. At Orleans, battering-rams were brought against the walls. All citizens, not under arms, were prostrate in prayer. The Bishop was anxiously counting the days and hours, when relief might come. A trusty messenger was sent to a neighbouring hill to look out for the expected aid, but twice he returned without intelligence. The third time he reported that a small cloud was visible in the distant horizon. "It is the help of God," exclaimed the Bishop- "It is the help of God."

The Roman and Gothic armies were now fast approaching for their relief. Attila at once raised the siege, and ordered a retreat. He was, however, followed by the brave Roman General, Etius. Although beaten in one or two engagements, he assured his followers that the Roman 
and Gothic successes were insignificant; and cHap. xIv. encouraged them with promises of the protection of Heaven, and safety against the darts of their enemies. "I will myself," he said, "throw the first javelin; and the wretch who refuses to imitate the example of his Sovereign, is doomed to inevitable death."

The decisive battle was fought on the plains attila of Chalons, in which it was stated that 300,000 Chalons. were slain. Victory crowned the Romans and the Goths; but Theodoric, the King of the Goths, had fallen. Notwithstanding this severe defeat, the terror of Attila's name continued. He was compared to a lion, encompassed in his den, and threatening his hunters with renewed and redoubled fury. And the Romans were beginning to feel that, if the Huns were annihilated, the Goths would turn against them. The Huns retreated for the present to the Thuringian Forest, where they massacred their captives and hostages, and left their bodies on the ground to the dogs and the vultures. Again Attila demanded Honoria, and was again refused. To strengthen his position, and to further his suit, he had from the beginning made a profession of Christianity, and had been baptized.

And now, having been again refused, he assaulted Aquileia, the richest and most populous 
CHaP. xiv. city of Italy, on the Hadriatic coast, with stones, The destruc- darts, and fire. Three months it resisted; and
tion of Aquileia. Attila was about to retire, when, as he was riding round the walls, he observed a stork with her infant brood, flying into the country, from her nest in one of the towers. This he regarded as a good omen, signifying that the city was doomed. He resumed the siege, and made the first breach, where he had observed the departure of the stork. The destruction of the city was so complete, that the ruins in the following generation were scarce discernible. The refugees formed, upon the neighbouring islands, the nucleus of what was afterwards the most famous city of Venice.

Attila now hastened on towards Rome, to deal his final and decisive stroke. The Emperor and Senate sent out to meet him a distinguished embassy; of which the principal person was Leo, Bishop of Rome, known as Leo the Great; distinguished alike for his learning, and his championship of the Church. The embassy was introduced; the barbarian listened with respectful attention. He promised to spare Italy, if the Princess Honoria was surrendered. At the same time, he had resolved to march his army up to the gates of Rome. He was warned that Alaric survived his assault of the city but a little while. His fears were aroused. He felt the power of 
Leo. He was awed by his eloquence, by his chap. XIV majestic form, and by his sacred robes. The sight of this great spiritual father excited his veneration. Moreover, he had seen in a dream the two Apostles, Peter and Paul, the great spiritual guardians of the city, threatening him with death, should he reject their prayer to spare the city. Attila retreated, and Rome was saved.

From these examples, it will be seen that the true and certain defence of the Church is the Death of fear of God, and a trust in His present help. Missionaries go into the world with this confidence, and contend with success against spiritual wickedness in high places, against the darkness and cruelty of heathenism, against the blight of infidelity and immorality, against the fierce tempers and cruel arrogance of conquering princes, against every stronghold of Satan. Often has the enemy perished--the victim of his own folly and vice. Alexander perished thus, at the age of thirty-two; and Attila, on his retreat from Rome, married a fair maid from beyond the Danube, and, on the morning after his nuptials, was found dead in his bed.

Waves of population continued to flow from East to West. The Franks settled in Gaul, and Mrigrations gave it its present name of France. The Anglo- to West. Saxons proceeded still further west, and crossed 
Chap. xiv. over into England. The Danai fixed their abode in Denmark; and the Frisians, who settled in Holland, have left their name in the province of Friesland. The Huns found a home at last in the extensive territory of Hungary. The general name, by which these migratory nations was known, in their mixed condition, was Germans. This succession of heathen tribes beat upon the Christian provinces of Gaul and Britain; and for some time threatened the very existence of Christianity in the West; inflicting untold miseries upon Christians and heathen alike. But Christianity triumphed in the end. Numerous missionaries went out from Britain and from Rome; and stemmed the tide of heathen idolatry and superstition.

Two centuries after Attila, the Franks had Conversion become Christian, through the influence and
of Clovis and the Franks. example of their great leader, Clovis. The family of Clovis appointed officers of the household, who became powerful governors over the provinces of the kingdom of the Franks, and were named Mayors of the Palace. One of the most distinguished of these was Pepin d'Heristal; whose son, Charles Martel, was even more distinguished than his father, by his successful resistance of the tide of Mohammedan conquest.

Charles and his father were long engaged in 
subduing the heathen Frisians. Their chief, chap. xIv. Radbod, was compelled at last to yield, even to Conversion the extent of embracing Christianity. But when saxons, and he was about to be baptized, and one foot was nations of already immersed in the water, it occurred to him to ask the question, where his departed ancestors were. "In hell," was the cruel answer of the Bishop, who was standing near. "Mighty well, then," answered the old warrior, withdrawing his foot, "I will rather feast with my ancestors in the halls of Woden, than dwell with your little starveling band of Christians." Radbod died, as he had lived, a heathen. So did his son, who, however, permitted the introduction of Christianity among his people. Willibrod, a British missionary, was consecrated their Bishop at Rome; and, with the favour and assistance of Charles Martel, destroyed the idols of the Frisians, built numerous churches, and became the first Bishop of the city of Utrecht. Two brothers named Hewald, and a third man, known afterwards as the Apostle of Germany, also went from the shores of England to preach the Gospel, where it had not been heard, and to seal their testimony with their blood. 


\section{CHAPTER XV.}

MONASTIC INSTITUTIONS.

Themeans of During the early ages of Christianity, the
circulating circulating linowledge. means of circulating a knowledge of Divine truth were very limited, partly through the ignorance which prevailed, and partly through the labour and cost of multiplying manuscript copies of God's Word. Kings and nobles were frequently unable to write their names. Under these circumstances, we shall not be surprised that visions and dreams exercised great influence, that miracles multiplied, that pictures, which adorned the walls and roofs of churches, supplied the needs of the unlearned, that the cross became the favourite symbol of our redemption, and that every suitable and appropriate device was employed, whereby the unlettered might be instructed and impressed with the everlasting benefit of the Saviour's life, suffering, and death. The ministers of Christ became distinguished by their peculiar dress, and by the tonsure, which was intended to represent the crown of thorns. As 
printing was not invented until the fifteenth CHAP. xv. century, all books were in manuscript; and nearly all manuscripts were in a language unknown to the people, who were called laity, as distinguished from monks and clergy, who were specially set apart for their learning, and hence named clergy. Until the introduction of Christianity, many countries were entirely without opportunities of learning, and there was but little good ground where the seeds of knowledge could be sown, and where learning could take root and bear fruit for a long time, except in the monasteries, which served the purposes of both school, college, and university. Into these, all who wished to dedicate themselves to the work of the ministry entered early.

Monasteries, of which so many splendid ruins Monasteries exist in Britain, became too often the abodes of the homes indolence and vice. Young princes and nobles, and vice. in some instances, obtained royal grants of land in the name of religion; built a monastery, obtained their appointment to be the head, and then with their boon companions allowed and practised unbridled indulgence. No wonder these institutions fell into great discredit, and brought disgrace upon the name of religion. With the best government, they are liable to special abuses, from the difficulty of restraining 
CHAP. xv. the young dwelling together under one roof, and of guiding them in the paths of virtue, when the world, the flesh, and the devil present their attractions at the most susceptible period of life.

Monasteries at first centres of life and light.
But the monastic society, speaking generally, at first and for some time, consisted of earnest and zealous servants of God, whose lives were sincerely devoted to the spread of true religion. We have already referred to the monastery founded by Columba in Iona, and to others which looked to it as a mother. There is one, whose ruins are a source of deep interest to travellers in Scotland-the Abbey of Melrose. Connected with it stands the name of Cuthbert, who became Bishop of Lindisfarne in A.D. 685 . From his earliest years he had been devoted to a religious life. He entered the Monastery of Melrose. One of the presbyters was Boisil, whose holiness of life and spirit impressed Cuthbert deeply. From him he derived his knowledge of the Scriptures and his example of godliness. Boisil became Abbot, and on his death was succeeded by Cuthbert. Under the government of Cuthbert, the monastery flourished in numbers and in missionary zeal. The truth spread around far and wide among the border tribes of England and Scotland. The monks were sent forth to instruct the ignorant, to re- 
claim and rebuke the vicious, to administer the cHaP. $\mathrm{xv}$. Sacraments, to correct the practices of idolatry and the mysterious incantations of heathenism. Cuthbert himself would set out on these journeys for a week or even a month, sometimes on foot, sometimes on horseback, through the neighbouring villages and towns, as his predecessor Boisil had been accustomed to do. In these expeditions he would call the people together to hear the Word of God; and such were his powers of persuasion, and such the angelic brightness of his countenance, the hearts of his hearers were speedily convinced. They were fully persuaded of the truth and goodness of the message. He would then visit the mountainous parts, which others dare not, on account of the barbarous character of the inhabitants, whom he succeeded in winning to a better way and to a better hope. Such was Cuthbert, the Abbot of Melrose, when he was appointed to the bishopric of Lindisfarne. As Bishop, he lived with his clergy - as Abbot, he had lived with his monks-upon the Apostolic principle that none of them who possessed anything should call it his own, but have all things common.

He was Bishop for two years only. His time Cuthbert was occupied much in prayer, in commending $\begin{gathered}\text { Bishop of } \\ \text { Lindisfarne } \\ \text { or Holy }\end{gathered}$ to God's care and protection those intrusted to Islann. 
CHAP. xv. him, and in daily exhorting them to set their affections on things above. He was a bright example of his own teaching, a man of fervent love, patient in tribulation, of ready access to to all who sought consolation. He was divinely forewarned of his end.

Herebert, the friend of Cuthbert.

There was living in seclusion near Keswick, on an island in Derwentwater, a venerable man named Herebert, a friend of Cuthbert, whom he was accustomed to visit every year for spiritual counsel. Herebert heard that Cuthbert was in Carlisle, on the occasion of an ordination of deacons, and went to seek from his friend some further counsel, on which occasion the Bishop thus addressed him: "Remember, brother Herebert, and speak only on matters which are needful. For after this meeting, I know we shall meet no more in this world. I know my departure is at hand." Herebert, bathed in tears, fell at his feet, imploring him not to leave him behind, but, as his most true and faithful friend, to pray that they might leave the world together, and together enter the higher service of heaven. Cuthbert cheered him with the assurance that his request should be granted. They each returned to his home, saw one another no more in the flesh, but passed away, both on one day, the 20th day of March, A.D. 687. 
There was another famous centre of light in СНدP. xv. the Monastery of Jarrow, near the mouth of the The river Wear, in the county of Durham. To this Bede. belonged the Venerable Bede, the great historian of the early English Church, who spent his whole life in sacred study and literary pursuits. His writings consisted of commentaries and homilies upon the Scriptures, letters on ecclesiastical subjects, histories of Saints and Martyrs, the life of Cuthbert in verse and prose, hymns, a history of his own monastery and of the English Church, and books on philosophy and grammar.

The founder of the monastery at Jarrow was Benedict a nobleman, named Biscop, and afterwards known monts on the by the name of Benedict. He was minister of Oswy, the King of Northumbria. He left the army for a higher warfare; he left home and kindred for Christ, that he might receive a hundredfold more in this life, and in the world to come life everlasting-he forsook earthly for heavenly joys. He accompanied Alchfrid, Oswy's son, in his journey to Rome; on which occasion he assumed the tonsure and the monastic habit, and with him returned Theodore the newly appointed Archbishop of Canterbury who made him Abbot of St. Peter's, Canterbury, after Hadrian.

Afterwards he returned to the north, and 
CHAP. $\mathrm{XV}$ with the assistance and patronage of King

The

Monastery of Jarrow.

Egfrid, who had succeeded Alchfrid in the kingdom of Northumbria, he built the Monastery of Jarrow. He frequently visited the Continent, and introduced from thence builders in stone, and workers in glass, the manufacture of which had hitherto been unknown in England. The knowledge of these useful arts now spread over the country with the spread of Christianity. He also introduced from abroad sacred vessels and robes, of superior quality and workmanship. At the same time, he made a large collection of books of every kind, and formed a library. $\mathrm{He}$ also collected what were then held of great value as a source of health and life-relics of Saints and Martyrs. He also brought in an improved method of singing and chanting, as settled by Pope Gregory the Great, the author of that style of chant called Gregorian, first introduced into England by Augustine, and into the Church of York by Paulinus and his deacon, James. It was adopted by Benedict in his new Monastery of Jarrow. He also obtained a guarantee from the King against pillage and violence. The church of the abbey he adorned with sacred illustrations. There were paintings of the Virgin and of the twelve Apostles upon the roof. The Gospel story was illustrated on the south wall, 
and the visions of the Revelation on the north cilsp. xv. wall. In the remaining parts of the church there were illustrations of the incidents connected with the Incarnation and the Crucifixion. By these the interest and attention of the worshippers were arrested, and their minds were enlightened with heavenly wisdom through the eye, as they were through the ear, by preaching.

The life of the first Abbot Benedict was as abbot plain and humble as it had been in the service of the King. He was one of the humblest of the fraternity, and cheerfully took his part in threshing and winnowing the corn, in milking, in grinding at the mill, in the work of the garden and the kitchen. He would say, "Though I am a ruler, that is no reason for being proud and haughty, but rather for being towards my brethren gentle, affable, and kind." Thus cheerfulness and humility were combined with discipline and authority. He would even take his place at the plough or the anvil, giving at the same time spiritual advice to his fellow-workers. $\mathrm{He}$ would eat at the same table with them, and sleep in the same common room. Only a few days before his death was he taken into a separate room, that he might be more quiet. There the brethren all gathered round him, to whom he gave one by one the kiss of peace, 
CHAP.xv. while they wept and lamented the loss of so good and kind a shepherd.

Abbot

$\mathrm{He}$ was succeeded by Ceolfrith, who was Ceolfrith. Abbot in the time of Bede. He further enriched the monastery and church with illustrations of sacred history; for example, there was the picture of Isaac carrying the wood of his sacrifice alongside another of Christ carrying the wood of the Cross; there was one of the serpent lifted up by Moses in the wilderness, alongside another of Christ uplifted on the Cross. Death of the In this monastery the Venerable Bede lived,
Venerable Bede. and died A.D. 735. It is recorded of him, that as he drew near his end he was much distressed by shortness of breath. From Easter till Ascensiontide he spent day and night in praising and thanking God, in singing psalms, and instructing his pupils. As the end approached, he awoke in the night, and exclaimed, with outstretched hands, "O truly happy man! O King of Glory! Lord of all grace, Who hast this day ascended in triumph to Heaven, leave us not comfortless, but send us the promise of the Father, the Spirit of Truth. Alleluia." Then he burst into tears, and repeated what he had just said. He was about fiuishing his translation of St. John's Gospel, when the scribe, who 
was at his side, said, "Dear master, there is one chap. xv. small portion still lacking, but it is too much for thee." "It is no trouble," was the reply, "take thy pen and write quickly." Meanwhile he was making little presents to his brethren, and begging them to pray for him, when the scribe once again reminded him, "There is one sentence more, dear master, to be written." Again he answered, "Write quickly." "Now," said the scribe, "it is finished." "Well," he answered, "hast thou said 'It is finished.' Support me with thy hands, and I will pray in my accustomed place to my Father." And thus, on the floor of his cell, he knelt down and sang, "Glory be to the Father, and to the Son, and to the Holy Ghost." Then his spirit departed, and passed within the gates of the heavenly city. 


\section{CHAPTER XVI.}

MAHOMET.

Mahomet's birth.

State of religion in Arabia.
While the Anglo-Saxons were being gathered into the fold of Christ by the Mission of Augustine and his companions, in the East a young man was preparing for a most remarkable career. He styled himself the Prophet and Apostle of God; and as such he has been accepted and believed in by many people and nations for the last 1200 years. This was Mahomet, born at Mecca, in Arabia-a descendant of Ishmael, the son of Abraham and Hagar. He was, therefore, like the whole Arab people, connected with, and interested in, "the father of the faithful" and "the friend of God;" notwithstanding the Word of God, "Cast out the bond-woman and her son, for the son of the bond-woman shall not be heir with the son of the freewoman."

At the time of Mahomet's appearance, the Arabs of the south of Arabia were subjects of the Christian King of Abyssinia, but were themselves idolaters. Mecca was held sacred by the 162 
whole Arab nation, because of the Sacred Stone, chap. xvi. called the Caaba, to which annual pilgrimages were made from all parts of the country. The Arabs were divided into tribes, of whom the Khoreish were the chief; having charge of the temple and worship of Mecca. Another influential tribe was the Hashem, to which Mahomet belonged. He was poor, and had been early left an orphan; but he became the camel-driver of a wealthy lady, whom he afterwards married, and thus improved his position. He was unable to read or write, but he gained by travel and observation what he could not learn by books. He meditated much upon the condition of religion amongst his own people, amongst the Christians of the Greek Empire, and amongst the Jews, of whom there were several colonies scattered over Arabia.

In his enthusiasm and self-confidence, he con- Mahomet cluded that he had a mission from God. In Gabriel. visions, he believed he had conferences with the Angel Gabriel. He had been carried up beyond the seventh heaven, within two bow-shots of the Throne of Glory. His mission was to purge out idolatry, and to preach throughout the world the simple doctrine-" There is but one God, and Mahomet is the Apostle of God." In his visions, communications were made to him of parts of 
CHap. Xvi. the eternal law of God, written on palm leaves or mutton-bones; and these he treasured up. He had seen the whole revelation, written in letters of gold; but only instalments were given him, as necessity required. These were afterwards collected into one book, known as the Koran. It is the Mahometan Bible. The contents of this book are, in a great measure, extracts from the Old and New Testaments. Mahomet affirmed that since the Creation six men have been distinguished for sacredness of character, and as guides of mankind - namely, Adam, Noah, Abraham, Moses, Jesus, Mahomet-of whom the greatest was the last, with an authority to which all others must bow. He thus connected himself with Jews and Christians. His doctrine and worship are known by the name of Islam; and his followers by that of Moslems or Mussulmans.

Mission to his

His leading doctrine is the unity of God, and countrymer. therein he is at one with the Word of God. He was the enemy of idolatry in every form; and therefore at issue with his countrymen, and with Christians of his country, in their adoration of the images of the Virgin, of the Saints and Martyrs ; but also in the worship of Jesus, whom he held to be a prophet of extraordinary power, though he denied that He was God, or the Son of God equal to the Father. His mission was unwel- 
come for some time, both at home and abroad. chap. xvi. After several years of labour and earnest preaching, especially in the Temple of Mecca, to assembled pilgrims, he gained but few converts; yet the pilgrims spread his fame throughout Arabia.

He made no pretence to miracles, although First they were afterwards attributed to him by his disciples. It was said that trees met him on his journeys, that stones saluted him, that water issued from his fingers, and that a camel complained to him. He was believed to have cured the sick, and raised the dead. He preached eternal rewards for the faithful, and eternal torments for unbelievers. The rewards were just such as delighted the Arab soul-a paradise of groves, rivers, and fountains; of pearls, diamonds, and robes of silk; of palaces of marble, dishes of gold, rich wines, dainties, and numerous attendants; each possessing seventy-two houris, or black-eyed girls, of exquisite beauty and grace; and every capacity of enjoyment increased a hundred-fold. Such was the hope set before each believer. His first converts were his faithful wife, his slave Zeid, his cousin and pupil Ali, his father-in-law and successor Abubekr, and ten others. These were the fruits of three years' labour-from A.D. 609-612. After this, he pub- 
Chap. xvi. licly declared himself the Prophet and Apostle of God. At a family gathering, where all partook of lamb and milk, he made this appeal"Friends and kinsmen, I offer, and I alone can offer, you the most precious gifts-the treasures of this world and of the world to come. God has commanded me to call you to His service. Who among you will support my brethren? Who among you will be my companion and vizier?" For a while all sat in astonishment; and no response was made. Then his cousin Ali, a youth of fourteen, arose and said, " $\mathrm{O}$ Prophet, I am the man; whosoever rises against thee, I will dash out his teeth, tear out his eyes, break his legs, and rip up his belly. O Prophet, I will be thy vizier." Mahomet was in a transport of joy; and thus answered the remonstrances of his uncle-" If they should put the sun on my right hand and the moon on my left, they should not turn me from my course."

The Hegira or Flight of Mahoinet.

The city of Mecca, led by the Khoreish, who were rivals of the Hashem Arabs, disbelieved in him, and threatened him with the vengeance of the national deities. It was determined that he should be put to death for his impiety and presumption. He was saved by a flight from Mecca to Medina, where he found a considerable number of converts to welcome him. This flight, called 
the Hegira, occurred in the year 622. It is from chap. xri. the beginning of this year that Mahometan chronology begins. The Mahometan year is one of twelve moons; consequently less than the true year by eleven days. Moslems observe their Sabbath on a Friday; pray five times in the day; fast; give alms as far as the tenth, and, in some cases, as far as the fifth of their income; practise frequent washing of hands, face, and body; and when water is wanting, the sand from the desert is used. They have stated hours and forms of prayer; and prayers are said with the face directed towards the Sacred Stone of Mecca. Mahomet discouraged voluntary fasts, such as he had observed among the Christian monks of Egypt, and appointed the month of Ramadan as the one general annual fast. Although he prohibited the use of wine in this world, he includes it among the pleasures of paradise. He has described the judgment and dissolution of the world. He taught the doctrine of predestination, and that one is as safe in the thickest of the battle as in his bed. Hence a Mahometan enters calmly upon dangers from which others would shrink: so impressed is he with the destiny or inevitable course and order of every man's life and action.

After his flight, the Prophet entered upon a 
chap. xvi. new period in his career. Henceforth he supsupplements plemented preaching with the sword. He became ling with the a soldier as well as a prophet. Those who would sword. not yield to persuasion must yield to force. $\mathrm{He}$ had the natural disposition of every enthusiast, in his impatience to see the whole world in submission at his feet. Reason and argument were backed by the violence of fire and sword, and by the terrors of the world to come, painted in their darkest colours before the eyes of unbelievers.

In his ristress he seeks the help of Gabriel. The first object of the Prophet was to break the power of his enemies at Mecca, to purge idolatry from its temple, and to reduce the whole Arab nation to his obedience. He sent in every direction his summons to adopt the new faith. He even went so far as to call upon the Emperor Heraclius, the head of the Eastern Church and of the Eastern world, to do the same. The Emperor, who was at the time reducing the kingdom of Persia under his dominion, treated the summons with a smile of contempt. The Khoreish replied by a counter demand to return to the old faith, and by the siege of Medina, whither he had fled for refuge. Mahomet was now in great straits, called upon God for assistance and for the deliverance of his friends. And thus he prayed, " $\mathrm{O}$ God, if these few are destroyed, by whom wilt Thou be worshipped in the earth?" 
He desired the help of Gabriel and three thou- CHap. xvI. sand Angels. He then mounted his horse, and led the attack. Casting sand into the air, he exclaimed, "Let their faces be covered with confusion." His enemies fell back at the terror of his voice. A second battle was fought, during which it was rumoured that he was slain. $\mathrm{He}$ was seriously wounded, and many of his followers had fallen. In a third encounter, his enemies were hopelessly dispersed, and their tents swept away by a tempest of wind, hail, and rain.

The Jews also had been summoned to embrace Severity Islam. Mahomet had sought to propitiate them, Jowards. by directing that the face should be turned in prayer towards Jerusalem instead of Mecca. But the obstinate refusal to follow him, and give up the faith of their fathers, lost their city this honour. They answered, "We shall persevere in the faith and worship of our fathers, although we are without arms and ignorant of their use." Some were banished from Arabia, others, to the number of seven hundred, were driven alive into one grave, and their property wholly confiscated in revenge for their assistance of the Khoreish.

At length he came to terms with the hostile Final subtribe, honoured the city of Mecca by a pilgrim- Arabia. age, and made the customary procession seven times round the Caaba. By these means he 
CHAP. XVi. conciliated and won over their military leaders Caled and Amrou, by whose skill and prowess he soon after conquered Syria and Egypt. His old enemies were now prostrate at his feet, begging for mercy. "What mercy" he said, "can you expect from me whom you have wronged?" "We confide in the generosity of our kinsman," they replied. "And you shall not confide in vain," he said; "begone, you are safe, you are free." Idolatry was purged from city and temple, and every unbeliever was forbidden an entrance within the sacred enclosure. He then proceeded to insist upon the same exclusiveness for the new faith in the other cities of Arabia which he had secured in Mecca. One city pleaded for a truce of three years, and a toleration of the ancient worship. "Not a month, not an hour," was the stern reply. "At least," they pleaded, "excuse us the obligation to pray." "Without prayer," he answered, "religion is of no avail." He would have absolute submission. He thus secured the obedience of the whole of Arabia.

Expedition against Heraclius.

Mahomet had named three of his most faithful followers to succeed him in case of death, but all were slain in one great battle, one of them being his slave Zeid. He then appointed Caled, with the title of "The Sword of God," to take com- 
mand of his army. In A.D. 630 he declared war chap. xvI. against the Empire, and renewed his summons to Heraclius. In a severe and trying summer march across the desert, overcome with heat and fatigue, his troops seemed inclined to desert. He rallied them with a voice of thunder, warning them that they would find Hell much hotter than that desert march. He gave them fifty days of penance as a punishment. But the expedition against Heraclius could not be followed up. The health of the Prophet was fast declining, and he died A.D. 632 .

A little before his death, he called together Mrakes his brethren and followers, and inquired whom he had scourged unjustly, or whom he had spoiled, or whom he had defrauded, and he would make a full reparation. Only one made any reply. He said he was entitled to three drachms of silver. Mahomet paid it, and thanked him for having accused him then, and not at the day of judgment.

Although his successor in the Caliphate was Apuroaching not named, he pointed to Abubekr, his old friend, and father of his favourite wife. He requested that a last and supplementary revelation might be written down. He then described a further and final visit of Gabriel to this lower world. He also observed that the Angel of Death had 
CHAP. Xvi. not been allowed to take him away, except by his own permission first obtained. At length he raised his eyes, and, with faltering voice, he uttered his last words: "O God, pardon my sins. His death $\quad$ Yes, I come-among my fellow-citizens on high." and burial. It was believed by his enthusiastic Commander, Omar, that he was not dead, but, like Moses and Jesus, in a trance, and would soon return to the faithful. But the aged Abubekr replied, "Do you worship Mahomet, or the God of Mahomet? The God of Mahomet lives for ever, but His Apostle is mortal like ourselves." $\mathrm{He}$ was devoutly buried in Medina, where his tomb is still an object of great veneration to pilgrims on their way to Mecca.

Thus passed away one who laid the foundation of one of the mightiest Empires of this world, and of a faith which aimed for centuries at the absolute and universal dominion of mankind. 


\section{CHAPTER XVII.}

\section{MAHOMETAN CONQUESTS.}

Throughout the Church, Christian worship had Corruptions become more or less corrupted by the multiplica- Chureh. tion of images and pictures; by the elevation of Saints and Martyrs to the position of mediators after their death; and by the introduction of relics: the Divine blessing, it was believed, was assured to all who placed themselves under their patronage and protection. Consequently, faith in our Lord Jesus Christ, as the one Mediator between God and men, in Whom alone we have the hope of salvation, grew fainter; and holiness of life, which is the fruit of faith, became less and less conspicuous.

Idolatry had brought Divine judgments upon pivine Israel in days of old. They had been destroyed by siege ; they had been led into captivity; their Temple and city burnt with fire; and not one stone had been left upon another. Like sins brought upon the Christian Church like judgments. As Sennacherib, Nebuchadnezzar, and 
cr. xvir. Titus had proved a sword of Divine vengeance to Israel, such now were Mahomet and his successors to the Church of Christ. $\mathrm{He}$ and the following Caliphs proved ministers of fiery judgment, by whom unfaithful and idolatrous Churches were destroyed or purged.

Terms offered by Mahometan During his lifetime, Mahomet was occupied Generals. with the subjugation of his Arab countrymen. It was left to his successors-Abubekr, Omar, Othman, Ali, Moawiyah-to subdue the rest of the world. The Caliphs deputed the conduct of military expeditions to their most distinguished and trusted officers-Obeidah, Caled, and Amrou, for example. To every people against whom their forces were directed, the simple choice was offered of the Koran, the tribute, or the sword. They called upon every city and country, whether Christian or Pagan, to embrace the creed of the Prophet, or pay a stipulated sum, or fight it out.

The collquest of

They first advanced against Persia and Syria. I'ersia. The power of Persia had been shaken by recent struggles with the empire. The Persian King, Chosroes, was dead; and a youth of fifteen had succeeded him on the throne. After a series of disastrous engagements, they drove the young King from his dominions. He was pursued into the mountains of Turkestan, up to the very borders 
of China, where he was overtaken and slain; $\mathrm{cH} . \mathrm{xvII}$. and the banner of the Prophet waved in triumph over the whole East.

Then followed the conquests of the Christian The policy States of Syria, Egypt, North Africa, and Spain. Caliphs. The policy of the Caliphs is best described in the words of Abubekr, who succeeded Mahomet, A.D. 632. By a circular letter, he summoned the Arab tribes to his standard at Medina. "This is to acquaint you that I intend to send the true believers (Moslems) into Syria, to take it out of the hands of the infidels (Christians)." To his Generals he gave these instructions:- " Remember, you are always in the presence of God, on the verge of death, in the assurance of judgment, and the hope of paradise. When you make a covenant, stand to it, and be as good as your word. When you fight the battles of the Lord, acquit yourselves like men, without turning your backs. As you go, you will find some who live in monasteries (the monks of Syria and Egypt); and to this class, which belongs to the synagogue of Satan, with shaven crowns, give no quarter until they turn Mahometan or pay the tribute. On this condition let them be spared and protected in the exercise of their own faith." In accordance with this policy, at the present day, bodies of Christians are found in Moslem States, 
CH. xvir. enjoying an uncertain and capricious security. The tribute, however, frequently became oppressive beyond endurance, and was demanded with insolence and severity, which not seldom led to tumults and rebellion. Provincial Governors varied much in their character and disposition. Sometimes they were violent and rapacious; and then the lives of their Christian subjects were utterly wretched. In many respects their trials were a counterpart of those which had befallen the Jewish people.

Other conquests of Islam.
God's judgments fall without respect of persons upon all such as abuse their high position and privileges. The Eastern Christians were degraded from the position of rulers to one of hard bondage. Their sacred cities fell one after another. Damascus, where the light of Christianity had first penetrated the mind of the Apostle Paul, and where he began the defence of that faith which before he had destroyed; Antioch, where believers in Christ had first received the name of Christians, the centre of Gentile Christianity, whence the Apostle of the Gentiles had started on his missionary journeys into Asia Minor and Europe, and long a favourite residence of the Eastern Emperors; Jerusalem, the great centre of all true religious life and worship, dear alike to Jews and Christians, 
whose gates the Lord loveth more than all the cH. xvir. dwellings of Jacob; these, with the whole of Palestine, fell, and still remain, under the yoke of Mahomet. Syria, Asia Minor, and Eastern Europe, which had been blessed with the feet of Apostles; the whole of Egypt, which had been the granary of the world from the days of the Patriarchs, the refuge of Jesus in His infancy, the home of learning and religion, and of great Christian luminaries ; the north of Africa, which had been honoured and blest by the labours of Cyprian and Augustine; the whole of Spain, which early received the Gospel, and which the Apostle Paul had proposed to visit, yielded in rapid succession. The Caliphs in A.D. 718 were the absolute masters over an empire extending from India to the Atlantic, and held together by the sword and the Koran.

The Mahometan conquests were mainly the Checked work of one hundred years, beginning with A.D. Martel. 632. The first ten of this period witnessed the most decisive and rapid advances. At the end of the year 640, Syria and Egypt were at the feet of the Moslems. Their victorious career proceeded unchecked along the north of Africa to the Straits of Gibraltar; which still keeps in memory the name of Tarik, the Arab commander; signifying, as it does, the Mount of 
CH. xvis. Tarik. They marched onward through Spain into the south of France. There their course was effectually arrested at Tours, A.D. 732, by the great victory of Charles Martel, or "The Hammer," "Mayor of the Palace" of the Merovingian King.

Government The east of Jordan was the scene of the first Empire. memorable conflicts. Here Mahometans made their first assault upon the great Christian Empire. The Emperor was not only Christian, but absolute ruler and dictator, in all matters spiritual and temporal; and required the unquestioning obedience of all his subjects to his Governors or Viceroys. These were placed over the several provinces, and had their residences in the chief centres of population. They were not always faithful to their master; but in some instances raised successful rebellions, and seated themselves on the Imperial throne.

Capture of Bozrah.
The province east of the Jordan had for its Viceroy Romanus, who resided at Bozrah. He betrayed his trust on the approach of the Saracens, and avowed his treason and apostasy in these words:- " I renounce Him that was crucified, and whosoever worships Him. I choose God for my Lord, Islam for my faith, Mecca for my temple, Moslems for my brethren, Mahomet for my prophet." This pervert and traitor 
pointed out to the enemy a secret underground cH. xviI. passage, by which they might enter the city. We are told that the ramparts were crowded with holy crosses and consecrated banners; whereby Divine assistance, it was believed, might be propitiated.

After the capture of Bozrah, the Christian Battle of armies were severely beaten at Aiznaddin, near Damascus (A.D. 633) by the united forces of the Moslems, uncler Caled and Amrou. Such was the daring spirit of the Arabs, that one Derar rode up to the Christian lines alone, and kept at bay as he returned, with his single lance, no fewer than thirty, seventeen of whom he unhorsed.

The broken armies of the Christians fled to Refugees the walls of Damascus. This most ancient Damascus. city, through which Abraham had passed to the Land of Promise, remains to this day, large and populous, pleasantly situated among fragrant groves, upon the banks of the bright and sparkling river Abana; of which Naaman, the Syrian captain, said, "Are rot Abana and Pharpar, rivers of Damascus, better than all the waters of Israel ?"

The Governor of Damascus was Thomas, son- The in-law of the Emperor-as faithful as Romanus Thomas. of Bozrah was unfaithful. The city would have 
cH. xvir. surrendered, had not the Governor, with great spirit and promptitude, opened the gates, and led out his troops to give the besiegers battle. Over the principal gate was erected a lofty crucifix. The Bishop and clergy marched out with the army. A copy of the New Testament was borne in front of an image of the Saviour.

The

generosity of the Arab commander Obeidah.

Thomas was an excellent archer, and, with an arrow, laid low one of the bravest of the Saracens, named Aban; whose wife, after embracing her dying husband, seized his weapons, and, with her first arrow, pierced the Governor's standardbearer, and with her second the eye of the Governor himself. Though wounded, Thomas refused to leave his post, and in the silence of the night renewed his attack on the besiegers. After the siege had lasted nearly seventy days, terms were asked from the generous Abu Obeidah, the Arab leader. He allowed all who wished to emigrate, and take with them as much of their property as they were able; and those who remained might, upon payment of a specified tribute, keep possession of their houses, and have the use of seven of their churches.

The treacherous cruelty of Caled.

Just as this arrangement was being concluded, the fierce Moslem captain, Caled, entered the eastern gate of the city, opposite to that by which his colleague $\mathrm{Abu}$ Obeidah had been admitted, 
crying that no quarter should be given. The cH. xvir. streets flowed with Christian blood. The two Commanders met in the Church of St. Mary; and Abu Obeidah restrained the sword of Caled from shedding further blood. But the savage warrior, having been informed that certain of the inhabitants had obtained the favour of a safe departure, followed after them, under the guidance of a renegade Christian; and not one escaped, save the widow of the Governor Thomas. An immense fair was held in the town of Abila, a little distance from Damascus, attended by Christians from all parts of Syria. This was attacked, and left a solitary scene of desolation and blood.

After the conquest of Damascus (A.D. 634), 帒和ture of Heliopolis or Baalbek, the ruins of which are still the wonder of travellers, was assaulted and taken. Fresh forces of Christian soldiers arrived from the Asiatic and European provinces of the empire, and gathered upon the banks of the river Yermuk, which flows from the southern slopes of Mount Hermon. Here, again, thousands of Syrian, Greek, and Roman Christians fell by the sword of the Moslems. Many were pursued into mountains and forests, and there ruthlessly slaughtered. Many, missing the fords of the river, were drowned in crossing. The 
CH. xvir. Christians themselves confessed that these terrible disasters were a Divine punishment for their sins. Surrender of Then the hand of judgment fell upon the holy
Jerusalem. city of Jerusalem-a city revered by Jew and Christian, and by the Moslems held in reverence next to Mecca and Medina. An attempt was made by the Saracens to surprise it, but in vain. It was then regularly invested, and summoned to surrender. It was defended on all sides by deep valleys and steep ascents. After a four months' siege, during an inclement winter, the Patriarch Sophronius called from the walls for a conference. Articles of surrender were drawn up; but Sophronius refused to open the gates until the articles had been signed in his presence by the Caliph Omar himself. Omar agreed to take the journey from Medina to Jerusalem. He mounted his red camel, provided with a bag of corn, a bag of dates, a wooden dish, and a leathern bottle of water. When he arrived in sight of Jerusalem he uttered the usual cry of all Moslem armies, "God is victorious!" He entered the city without fear, and discoursed pleasantly with the Christian Patriarch. They proceeded together to the Church of the Resurrection. Sophronius invited him to enter, but Omar declined, and offered up his prayer at the door; saying that, 
had he entered, it might have led to a violation сн. xvir. of the treaty, and the forcible entrance of his followers. Orders were given for the building of a mosque, known as the Mosque of Omar, on the site of Solomon's Temple; where Mahometans have offered their solemn worship from that time to the present.

Then Aleppo was taken. The castle was Capture of obstinately held, until an Arab slave of gigantic size and strength boldly declared that with thirty stout men he would open its gates. Placing himself against the wall, he bore on his shoulders the weight of seven of the strongest, the uppermost of whom stealthily struck down the sentinels, mounted the wall, and drew up his companions one after another. The gates were opened, and the castle taken.

Antioch was spared by paying a ransom of surrender 300,000 pieces of gold; but she was deprived of and Antiocharea. her position, as the seat of Government, and reduced to a secondary city. The Emperor now withdrew from Syria, and left his son to defend Cæsarea, the last Syrian stronghold. But no defence was made. Cæsarea was delivered up to the enemy. All the remaining cities and towns followed the example, and the banners of the Prophet waved over the whole of that land, which had been hallowed by so many sacred 
cH. xvir. memories. The Emperor, before his final departure, acknowledged and bewailed the sins of both prince and people in the Cathedral of Antioch.

Capture of Memphis.

Alexandria taken, and her library destroyed.

The conquest of Egypt followed that of Syria. Amrou was intrusted with the Egyptian expedition. The division of the Egyptian Christians into Melchites and Jacobites-orthodox Greeks and Monophysite followers of Jacob-had long caused scandal and misery in the Church. The Divine anger, therefore, might well visit these enemies of Christ's law of love, peace, and righteousness. The first city captured was the ancient capital of Memphis, near the Pyramids. On the opposite bank of the Nile, afterwards rose the city of Old Cairo; followed later on, and at some little distance, by New Cairo, the present capital.

The Arabs then proceeded to Alexandria, to which they laid siege. It was considered the most difficult of all their enterprises. Once Amrou was betrayed, and brought into the presence of the Imperial Governor, who was deceived as to the rank and dignity of his captive, by the slave of Amrou striking his master on the face, and bidding him show due respect to the Governor. The Governor dismissed both master and slave; and bade them bring him more worthy ambassadors. After a siege of 
fourteen months, the Moslems prevailed, and cr. xvir. took the city. The famous library, which contained innumerable writings, sacred and profane, collected during many generations, was destroyed by the order of the Caliph Omar. "If these writings," he said, "agree with the Book of God (the Koran), they are useless; if they disagree, they ought to be destroyed." The Churches of Africa were almost annihilated, and the light of the Gospel all but extinguished. The door into Spain was opened by treachery. Through this whole course of Arab conquest, the labours of Christians for six centuries were buried in an impenetrable darkness of spiritual night; but the beams of the Sun of Righteousness shall yet again pierce those benighted lands; and when "the knowledge of the glory of the Lord shall cover the earth as the waters cover the sea," "the Morians' land shall then stretch out her hands unto God." 


\section{CHAPTER XVIII.}

IMAGE-WORSHIP.

Images condemned by Holy Scripture.
THE reverence of the human heart may be excited by visible representations of the Divine Being. But God is a Spirit, Whom therefore no man hath seen, or can see, or can represent by image or picture, by the likeness of anything in heaven, in the earth, or in the sea. God is a Spirit, Whom we must worship in spirit and in truth. All images and representations of the Deity are prohibited by the Second Commandment, which says, "Thou shalt not make to thyself any graven image, nor the likeness of any thing. Thou shalt not bow down to them, nor worship them, for I, the Lord thy God, am a jealous God." This Commandment the Roman Church has suppressed, because it is a condemnation of her Image-Worship. ${ }^{1}$

1 "It is a very probable supposition that the Commandments were inserted in 1552 to ensure the constant reading of the Second Commandment; they were also given at full length, instead of the curtailed Roman form, in which also 186 
Reason tells us that no figure could possibly CH. xviII. express the infinite majesty and love, the eternal Images justice and mercy of God. The Greeks endea- by reason. voured to express the greatness of the Deity by the Olympian Jove, Nebuchadnezzar by the image of gold of immense height, the Assyrians and Egyptians by gigantic figures cut from the solid rock. Christians have so far kept the Commandment as to limit their image-making and image-worship to the Second Person of the Blessed Trinity, and to His human nature. But no image can convey blessing, or receive the homage and allegiance which we owe and should pay directly to Him Who is at the Father's right hand. Can it be pleasing to the Son of God to be represented by a figure of wood and precious stone, silver and gold?-by a figure diverting and alienating our thoughts from His eternal glory and His Divine nature, and also from the full benefits of His humiliation, His infancy, His agony, and death on the Cross.

The only true likeness of Christ is that which The Gospel has been written in the Gospel, by the pen of likeness of inspiration, and transcribed by the Holy Spirit a clause of the Second is joined to the First."-Procter On the Book of Common Prayer, p. 341 note.

"Then followed" (in King Alfred's Code of Laws) "the Ten Commandments, omitting the Second."-Dr. Pauli's Alfred the Great. 
cH. xvir. upon the hearts of believers. Shall we leave the contemplation of the Gospel for that of an image, or worship the creature rather than the Creator?

No images in Chureh for three centuries.

Mahomet felt that no true likeness of God could be formed except in the mind, and that by a Divine inspiration and revelation. He therefore provided what he declared to be a revelation in the Koran. The heathen themselves felt this when they declared that the image of Diana, worshipped by the Ephesians, had fallen down from Jupiter. This was also felt by the early Christians. There is no authority for any representation of Christ by an image either in the New Testament or in the writings of Christians of the first three centuries. The advocates of images are reduced to the authority of a fable.

Images of Christ : their origin.
Abgarus, King of Edessa, is reported by Eusebius to have received a special message from the Saviour, in reply to a letter, offering him a refuge from the malice of the Jews. It was afterwards reported that with this letter. Jesus had sent a likeness of Himself impressed on linen. But, after being lost five hundred years, it was discovered in a niche of a wall. It was believed to have been the deliverer of Edessa from the arms of Chosroes, King of Persia. The inhabitants were assured by it that their city never could be taken by any foreign foe. A hymn was composed 
in its praise: "How can we with mortal eyes con- cr. xvirI. template this image, Whose celestial splendour the hosts of Heaven presume not to behold! He Who dwells in Heaven condescended this day to visit us by $\mathrm{His}$ venerable image. He Who is seated on the cherubim visits us this day by His picture, which the Father hath delineated by His immaculate hand, which $\mathrm{He}$ has formed in an ineffable manner, and which we sanctify by adoration, fear, and love."

By the end of the sixth century copies had Images of been multiplied and circulated everywhere in stie virgin,s, public and in private. Some of these copies were Martyrs. brought that they might have contact with the original, and thus acquire the power of healing, and of giving victory in battle. From images and pictures of Jesus, their devotees proceeded to the discovery of the likenesses of the Virgin, and of the Saints and Martyrs, which also multiplied and came into general use. The features of the Virgin had been discovered deeply cut in a marble column of the Church of Diospolis, in Palestine.

This prevalence of image-worship not only pro- Revolt voked the mission of Mahomet, but a fierce contest Images. arose within the Church itself. It was strongly felt in the more remote and less luxurious provinces of the Empire, and especially in the neighbourhood of Mahomet's first enterprises 
CH. xvirI. against idolatry in the mountains of Asia Minor, that Christianity was sorely compromised by a worship and service akin to that of heathen idolatry, from which Christianity was the special deliverance. A grievous departure had been made. The old evils had revived. Christianity had been polluted and trampled down in the mire. What was to be done? Did not Hezekiah take and destroy the brazen serpent, when it had become the object of worship? Did not the reforming Kings of Judah destroy the idolatrous altars? Had not the prophet said, "The idols ye shall utterly abolish"? Had not the Lord said, "I will not give My glory to another, nor My praise to graven images"? And ought not these pollutions of Christianity to be destroyed, and Christian worship reformed?

Leo, the Isaurian.

The Emperor Leo III. put himself at the head of a movement for the accomplishment of this object. He had raised himself to the throne of Constantinople, A.D. 718. He had marched in triumph at the head of a body of Roman troops from the mountains of Asia Minor. His followers were animated by a violent indignation against the images, whether they were found inside or outside the churches. They were named Iconoclasts-that is, image-breakers. A story was circulated to discredit Leo. It was said that he 
had been an itinerant pedlar, who drove an ass to cH. xviII. the country fairs with his paltry merchandise, and on one occasion he had met some Jewish fortunetellers, who had promised him the Roman Empire if he would abolish idolatry.

For some time after his accession Leo the Isaurian, as he was named, from the country of his birth, showed some outward reverence towards images. He first ordered them to be elevated beyond the reach of the worshippers; opposition to this order drove him to the complete removal of every object of adoration, the destruction of every picture, the demolition of every image, the plastering of every wall on which a sacred figure had been or might be cut. He next sought to make the condemnation and destruction of images an article of the faith. For this purpose, what has Iconoclasm sometimes been termed the Seventh General article of Council was summoned by Constantine V., the A.D. 554 . son of Leo, who was actuated by the same iconoclastic spirit. The Council numbered 338 Bishops, from Europe and Asia Minor. It was decreed that all visible symbols of Christ, except in the Eucharist, were blasphemous; that imageworship was a corruption of Christianity, and a revival of Paganism; that all monuments of idolatry should be broken; that all who refused to give them up should be deemed guilty of dis- 
cH. xvir. obedience to the Church and the Emperor. The Emperor was charged with the execution of these decrees.

The rising in The first assault was made on a lofty image of defence of the Images.

Christ above the gate of the palace. A ladder was placed, the ministers of destruction mounted, but the infuriated crowd overturned it, and the sacrilegious invaders were dashed to the ground. The defenders of the image were put to death, and by their friends were accounted martyrs. Tumults were caused by the Iconoclasts everywhere. They proceeded to the islands of the Archipelago, which were crowded with images of the Saviour. The inhabitants at first made a show of yielding; but soon after raised a fleet, and sailed to Constantinople, for the purpose of dethroning the Emperor. They failed, and their fleet was destroyed by Greek fire.

St. John of Damaseus and the Monks.
During the absence of the Emperor, who was on an expedition against the Saracens, the images were restored. The most distinguished advocate for their restoration, and the most bitter antagonist of the Emperor and the Iconoclasts, was St. John of Damascus. The monks generally were most zealous in the defence of image-worship, and the determined opponents of Constantine. He decreed the abolition of their order. He converted the monastic buildings into barracks or 
magazines, confiscated their lands, and dissolved $\mathrm{cH}$. xvir. all religious communities. The Visitor-General, charged with this work, was named " the Dragon." There was much destruction that was purely wanton and malicious. All image-worship, public or private, was proscribed, and a solemn oath was required of the clergy to renounce idolatry.

His Iconoclasm brought the Emperor into con- The Bishop flict with the Bishop of Rome. The circumstances of Rome's of the time were specially favourable to the increase of Papal power. The Emperor was still sole ruler of the East and West, and Italy formed part of his dominions. He had his Viceroy, called Exarch, at Ravenna. Here was the seat of government for all Italy, the city of Rome included. A very considerable portion of the Imperial dominions had been lost by the Mahometan conquests, and the remainder was torn by internal strife. In this condition of Imperial weakness, it was hoped that the ancient preeminence of Rome, the old capital, might be re-established, under the shadow of St. Peter and his successors. It seemed an inviting opportunity for throwing off the Imperial yoke altogether, and establishing the position of the Pope as a temporal sovereign.

This marks a new era in the history of Christianity. Hitherto Greek influence had prepon- 
cr. xvir. derated in the Church. The period which now The ecclesi- begins is to witness the prevalence of Latin influ-
astical and temporal
power trans- While the Church was in this transition ferred. state, the civil power was passing from Latin to Teutonic or German control. The new powers in Church and State strengthened each other's hands-the Latin Church, under the Popes, supported the Teutonic rulers, Charles Martel, his son Pepin, and his grandson Charlemagne. The last of these was made a Roman patrician, and then crowned "Emperor of the Romans," A.D. 800, by the Pope. On the other hand, these rulers guaranteed the privileges and possessions of the See of Rome, did homage to the Chair of St. Peter, and received a commission to march against all the enemies of the Church, but especially the Lombards, who then overran Italy.

Letter of

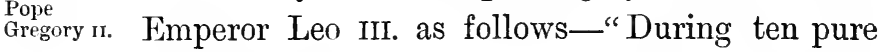

In the year 727 Pope Gregory II. wrote to the and fortunate years we have tasted the annual comfort of your royal letters, the sacred pledge of your attachment to the orthodox creed of our fathers. How deplorable is the change! You now accuse the Catholics of idolatry, and by the accusation you betray your own impiety and ignorance. Were you to enter a Grammar School, the simple and pious children would be provoked to cast the inkhorn at your head. You declare, 
with foolish arrogance, 'I will despatch my orders cH. xrin.

to Rome, I will break in pieces the image of St. Peter.' Are you aware that the Popes are the bond of union, the mediators between the East and the West? The eyes of the nations are fixed on our humility, and they revere, as a god upon earth, the Apostle St. Peter, whose image you threaten to destroy. Abandon your rash and fatal enterprise. Reflect, tremble, and repent." He goes on to defend the images, as being genuine representations, as having been adored from the beginning of Christianity. $\mathrm{He}$ asserts that the Christian world until now had been unanimous on this point-a fact of more weight than the decrees of a Council, even when summoned by an orthodox prince. He lays down the respective bounds of civil and ecclesiastical power. The one possesses and controls the body, the other the soul; the one holds the sword of justice, the other the weapons of excommunication.

The success of the Iconoclasts was, on account Failure of of the growing influence of the Popes, by whom clasts int images and image-worship were defended, not so great in Italy as in the East. The Greeks who came into Italy for the destruction of images were for the most part overthrown in battle, and massacred. The Exarch of Ravemna was slain in a 
cH. xvirr. tumult of the opposing parties. The Pope himself took up arms, and met the invaders. The Emperor's own statues were destroyed in retaliation. The Greeks were swept out of the Peninsula. Their blood mingled with the waters of the Hadriatic. The Emperor's authority had all but vanished in the midst of the anarchy that prevailed. A synod was called, and presided over by the Pope, in which the heresy of the Iconoclasts was condemned, and all who, by word or deed, attacked the images of the Saints were ordered to be executed. While Italy was declared to be free, Italians were exhorted to retain their union with the Empire, and to allow the Exarch his residence at Ravenna, until, in the end, the Pope transferred the Empire to Charlemagne, and crowned him in the imperial city of Rome.

Image- Upon the death of Constantine v., Leo Iv., Worship
established his son and successor, carried on the war
in the West. with the images, but with less vigour. A powerful influence was exercised in their favour by his wife, Irene. She caused every office in the Church, as it became vacant, to be filled with her adherents. She called a Synod at Nice, where the Iconoclasts appeared as criminals on their defence. It was decreed that the worship of images is agreeable to 


$$
\text { Image-Worship. }
$$

Scripture and reason, to the Fathers and Coun- ch. xvirl. cils of the Church. In Rome the Pope accepted and published these decrees throughout his diocese. The Churches of France, Germany, and England took a middle course between adoration and destruction, admitting them into the Churches as memorials of the faith, and illustrations of sacred history. The Council of Frankfort, A.D. 794, blamed the fury of the Iconoclasts, and, at the same time, censured the superstition of image-worship; still, in the West generally, image-worship made steady but silent progress. 


\section{CHAPTER XIX.}

IRISH MISSIONARIES.

The Gospel spreads over and beyond the Empire.

THE spread of the Gospel has been compared by the Saviour to that of leaven, which a woman took and hid in three measures of meal. The ancient world consisted of three parts-Europe, Asia, Africa. The Roman Empire embraced some portion of each; and, within the limits of the Empire, the Gospel first exercised its leavening influence. At the end of the fourth century of the Christian era, began those numerous and desolating invasions from the north-east of Europe, opening new fields for Christian effort. The conquerors who subdued the provinces of the Empire, needed themselves to be subdued to Christ. This was the work of the next four centuries, which ended with the coronation of Charlemagne.

Church

herself

The progress of Christ's Kingdom is gradual imperfectly and imperceptible, as the leaven in its operation and influence. Its conquests are not sudden and startling; its victories are not all at once com198 
plete; the corruptions of the age and of the chap.xix. natural heart are overcome by degrees. The light of truth does not immediately or entirely dispel the darkness of superstition, ignorance, and error. Heresies are the fruit of an imperfect conquest. They may imply a too rapid progress. The image-worship which prevailed in the Church for a time indicated that the meal was too much for the leaven; that the world of idolatry and superstition was too strong for the Church fully to restrain, with her present gifts and graces. When the Church herself was so imperfectly influenced by the leaven of Divine truth, no wonder that her influence over the spirit and character of the heathen was imperfect.

The progress of Christianity was not always silent pro. due to great names which have been conspicuous Christianity. on the pages of history. Great names rise above the general mass of mankind, rather as signs and tokens of the work that is going on around, than as the doers of it. The grace of the Holy Spirit is hidden from the eye of the world, and works by numberless weak and feeble instruments and by insignificant channels, of which the world takes no account. But the record is in Heaven. Churches have been planted and have prospered in many spots, of which history can 
CHap. xIx. tell us nothing as to their origin. It is the pride of some Churches to be able to trace their origin to the labours of some distinguished Apostle, Saint, or Martyr. But those which have been so manifestly honoured are few. Even at Rome there was a Christian Church before it was visited by an Apostle. A Church existed there before St. Paul wrote his Epistle to the Romans; organised Christians found their way to Damascus and other cities of the East before the Apostles left the neighbourhood of Jerusalem. Whence came they?-and who guided them thither? We are apt to attribute too much to visible means and instruments, and too little to the silent influence of the Holy Spirit, working in unknown and unnoticed channels. The ascended Saviour, at His own time and in His own way, which is not always, nor exclusively, by the instrumentality of organised Churches, works secretly and mysteriously, yet efficaciously, in the hearts and minds of mankind.

There is one Church, outside the limits of the Roman Empire, whose origin is lost in obscurity - the ancient Church of Ireland. It is said that Pope Celestine, at the beginning of the fifth century, sent Palladius to win the Irish to the Christian faith, but that his mission was a failure. And he was not sent to a heathen people, wholly 
ignorant of the faith, but to the Scots (this was chap. xix. the original name of the Irish) believing in Christ. He landed with twelve companions in Wicklow, baptized a few converts, and built three wooden churches; but from the opposition of the chiefs, he was obliged to leave Ireland. He retired to Scotland, and died there.

In the following year, A.D. 432, came Patrick, Captivity of the Apostle of Ireland. His life has been so much involved in fable, that his very existence has been doubted. The principal authority for his life and work is his Confession, and a letter written by him to a chief named Coroticus. His father was a Christian deacon, and his grandfather a priest. His birthplace was probably Kirkpatrick, between Dumbarton and Glasgow. At that time the west coast of Scotland was frequently disturbed by predatory incursions from Ireland. Many Christians were carried off, and became the slaves of Irish chiefs. This was the lot of Patrick and his two sisters. They were conveyed into the county of Antrim. Patrick was set to tend the flocks of his master, and exposed to many hardships. He was sixteen years old, and served six years, during which he learnt the native language, laws, and customs. By one of their laws all Irish slaves were free at the end of six years' service. Patrick, therefore, escaped 
CHAP. xix. from Ireland, and returned home, but was again carried off, and again escaped.

His call to teach the Irish.
But now he heard voices calling upon him to leave his country and his father's house. He had often thought in his captivity how blessed he would be if, knowing the true God and His Son Jesus Christ, he could deliver the good news to his old master and his people. He had a dream, in which he beheld a man coming from Ireland with letters. One of the letters was delivered to Patrick, in which he read the words, "The voice of the Irish." He thought he heard the people calling across the sea, and saying, "We entreat thee, holy youth, to come and walk among us."

Consecrated Bishop and labours in Ireland.
He left his father's house in Scotland, and repaired to the monastery of St. Martin of Tours for his training. He also spent some time in the seminaries in which Germanus, Lupus, and Hilary of Arles had studied. Patrick is said to have returned to Britain, A.D. 429, in the company of Germanus and Lupus, who had come to refute the Pelagian heresy. He was probably consecrated Bishop in Gaul. He proceeded on his way to Ireland, with a few fellow-labourers. There was considerable opposition to his landing, but he succeeded in getting ashore at Holmpatrick; and after some few conversions he sailed for Dundrum 
Bay. There the chief mistook him for a pirate, cHup. xIx. and was on the point of putting him to death; but, struck with his reverend demeanour and aspect, and the absence of armour, he received him with hospitality. He also gave him a piece of ground on which stood a barn, which afterward became the famous church, called the Barn of St. Patrick. Some ruins of it are still to be seen near the village of Saul, in the county of Down.

The missionary was determined, if possible, to The Druids win his old master, but failed. He then visited the celebrated Hill of Tara. It was Easter, and a great festival was about to be held by the Druids. When he was near he erected a tent, and kindled a fire. The curling smoke was observed by the Druids with the greatest consternation. To light a fire before the King had lighted the sacred fire in the palace of Tara was a heinous sin. The King was warned that if the strange fire was not extinguished that night, he to whom it belonged would be sovereign of Ireland for ever. The Druids had in all probability heard of the Gospel messengers, and of the success of their message in other lands, and felt the impending doom of their old superstition.

The offenders were summoned before the King. Their fearlessness commanded his respectful atten- 
CHAP. XIx. tion, and that of his nobles, to their message.

Great success.

The Letter to Coroticus and the Apology.

Permission was also given them to preach where they pleased within his dominions, if they did not disturb the peace. Missionary tours were made into West Meath, Connaught, Mayo, and Ulster. The Druids threatened, but were prevented from putting Patrick to death by the favour of the King. The great idol Crom Cruach was destroyed. The seven sons of the King of Mayo were baptized. Patrick was joined, A.D. 439, by three friends, all of them raised to the episcopal office in Britain or Gaul. He was thus enabled to extend the work of preaching, baptizing, building churches, founding monasteries and schools.

It was during his labours in Munster that he wrote the letter which contains the leading events of his life. Descents were made upon the southern coasts of Ireland from Wales and Cornwall. On one occasion some converts, whom Patrick had recently baptized, were carried off, and, as was customary, sold into slavery, a practice which continued for several centuries later. A letter was written by Patrick to the pirate chief Coroticus, begging that he would restore them to their home. His Confession, which was written towards the close of his life, is an apology for having chosen missionary work, wherein he pleads his 
success as his chief justification. Ireland he CHAP. XIx. studded with monasteries, in which the Scriptures were read, books collected and copied, missionaries trained, who went forth to evangelise the still barbarous and idolatrous nations of Europe.

Patrick ended his days in peace at the village "The of Saul, the scene of his first successes. He left saints."

a Church which was the glory of Ireland, and the light of the West; a Church protected by the native chiefs, and presided over by a numerous and well-informed clergy. The work was so far blessed, that during the next hundred years Ireland was called " the Garden of Eden," "the Island of Saints." The Irish Church had in it the true missionary spirit.

Those countries of Europe which formed the Irish fringe of the Empire often witnessed the restora- Columbinn. tion of idolatry, instead of the trimphant and unchecked progress of the Gospel. Many tribes of Southern Germany, on the Phine, in Switzerland and Lombardy, had fallen into their old superstitions, through the laxity and indifference of converts to the advantages and blessings of true and pure Christianity. It was to some of these countries that the Irish Missionaries directed their energies. The principal figure in the noble band was Columban, a native of Leinster, born A.D. 
CHAP. XIX. 543, educated in a monastery on Loch Erne, and in that also of Banchor, on the coast of Ulster.

The mission At the age of thirty years he set out with his
to Luxeuil. twelve companions for the neighbourhood of the Rhine, where he was welcomed by a grandson of Clovis, King of the Franks. Clovis had led the Franks to the conquest of Gaul, afterwards named France, and the expulsion of Roman power. Monasteries were a necessity in those troubled times, as a home for religion and new converts; as a refuge from violence and rapine; as a retreat from the manifold dangers and temptations of the world. Columban's first object was to obtain a site for such an institution. He settled first at Annegray, then at Luxeuil, near the foot of the Vosges; a spot which had witnessed many an act of cruel devastation and barbarism. It was now the haunt of the wolf and the bear. The Mission party were reduced to the greatest want, even to feeding on the bark of trees and wild herbs.

The Monastery of Luxenil. The monastery was erected on the plan of those of his native island, with cells of thatch and wattles, with a church and its round tower. The fields were sown with corn. People flocked by hundreds to hear from their lips the word of life-for instruction in temporal as well as eternal things ; in the cultivation of their land as well as their hearts and minds. The inmates of the 
monastery were placed under the strictest discip- CHAP. XIx. line. Their employment was carefully arranged between the field, the monastery, and the church. All offences against the rules were punished by a period of enforced silence, by taking some humiliating position, or even by corporal punishment. Six blows were inflicted if one failed to join in the "Amen" after the grace or the Bishop's blessing; or for neglect in signing his cup with a cross, or for talking too loud, or for coughing during the singing of the psalms, or for staring about during Divine service. Insubordination was visited by a heavier punishment. The number of blows might amount to 200 ; but not more than twenty-five could be administered at one time. Columban's principles were, "Whoever over- Columban's comes himself, treads the world under his feet." "If we have conquered ourselves, we have conquered all things." "Let us live in Christ, that Christ may live in us." He frequently rebuked the vices of the Frankish clergy, and held his own against the Frankish Bishop upon many controverted questions. His great desire was to live in peace, although his eyes would flash like lightning upon the vicious, and his words would peal on their ears like thunder. "Let us not quarrel," he would say, "lest our enemies, the 
CHaP. XIx. heretics and Pagans, rejoice over our contention. Let us delight in the faith and revelation of the Son of God, and let us strive earnestly together to attain unto a perfect man, unto the measure of the stature of the fulness of Christ. Let us learn in holy communion with one another to love one another, to praise one another, to correct one another, and to pray for one another, that with Him we may reign together for evermore."

Persecution of Brunehaut.

He did not shrink from censuring the grievous licentiousness of the Court, at the head of which was the unscrupulous Brunehaut. She had fled for refuge to her grandson, the King of Burgundy, Theodoric II. His vices she encouraged. She prevented him from taking a lawful queen, lest she might be deprived of her authority and influence. Columban refused his blessing upon the four illegitimate sons of Theodoric, which she sought. She had already put to death the Bishop of Vienne, and now she persecuted Columban, by cutting off the supplies of his monastery. He again visited the Court to remonstrate. A sumptuous feast was prepared, but he would not taste it. It is said his thunderings were followed by a miraculous destruction of the dishes, and of the meat and wine, with which the table was laden. His life was now in extreme danger, and he was forcibly removed from city to city, then placed 
on board a boat sailing to Ireland. But a storm chap. xix. drove him back upon the coast of Neustria.

Columban now turned his thoughts to Helvetia, columban and thither he was accompanied by his friend labbour in Gallus, better known as St. Gall. At Zug, Helvetia.

on the lake of Zurich, they interrupted a heathen festival, which almost caused their expulsion from the country. From Zurich they proceeded to Lake Constance. Bregenz was pointed out by the good Bishop as a suitable site for a monastery. Here they discovered that one of the churches had been converted into a heathen temple. The three images which they found in it were destroyed and thrown into the lake.

It is also related of St. Gall that, as he was The spirit of fishing one night on the lake, he heard the Spirit thin and of of the mountain calling to the Spirit of the waters, the deep. "Arise, and come to my assistance. Behold, strangers have driven me from my temple. Haste to the rescue, and help me to expel them from the land." The Spirit of the waters replied, "Lo! one of them is busied on my surface, but injure him I cannot. Often have I tried to break his nets, but as often have I been baffled; for the invocation of an all-prevailing name never fails to cross his lips." Gallus trembled; but he thus addressed the Spirits: "I adjure you, in the 
CHap. XIx. Name of the Lord Jesus Christ, that you depart from this place, and never more injure any one." He then hastened to the monastery, where he reported all that he had heard; and his brethren rejoiced that the spirits were subject unto them.

Columban dies in Lombardy.

Columban went still farther into Lombardy, and, after founding the monastery of Bobbio, died at the age of seventy-two. Gallus laboured on, and founded the monastery of St. Gall, famous for many ages as a seat of learning. His deacon, John, became the Bishop of Constance. St. Magnus and St. Kilian belonged to this noble band of Irish missionaries. The Kingdom of Heaven was thus extended, while earthly kingdoms and empires were declining; and nations, which had never been included within the Roman Empire, now laid down their arms at the feet of Jesus. 


\section{CHAPTER XX.}

CHARLEMAGNE.

The Bishops of Rome at the end of the Increasing eighth century had obtained a powerful in- the Popes. fluence over Kings, as well as over all other Bishops. Their counsel and sanction were sought in every important crisis of Church and State. Their most zealous sons went forth as missionaries in every direction. Kings, princes, nobles, bishops, abbots, lent their authority and influence, by direction of the Popes, in the propagation of the faith, in the foundation of abbeys and churches. Conquering princes were charged to give no option to the people whom they subdued, except Christianity or expulsion from their homes. To this policy Pepin and Charlemagne especially dedicated their power and influence. They were the princes who established the Carlovingian line of French kings upon the wreck of the Merovingian.

The Franks were a German tribe from the Invasion of country between the Rhine and Elbe. They first Franks. invaded Gaul, when the Saxons and Angles 
CHAP. xx. began their invasions of Britain. The limbs of the Roman Empire now in a rapid decay, were the prey of the gathering eagles. The Franks were led by Clovis, who was a Pagan, but had married a Christian wife named Clotilda. Gaul had been added to the Empire by the conquests of Julius Cresar. It had been Christian from the earliest days of Christianity. It had its long lines of noble Bishops in the chief cities. It had its martyrs and apologists and defenders of the faith,-Pothinus, Irenæus, Hilary of Arles, Hilary of Poitiers, Germanus, and Lupus.

Conversion and baptism of Clovis.

Clovis, by one great victory at Soissons, A.D. 486 , brought this rich province under the dominion of the Franks. He believed that his success was due to the God of the Christians. He therefore accepted the faith of Christ, and was baptized with great solemnity in the Cathedral of Rheims. He had been convinced by the Bishop Remigius, known as St. Remy, of the temporal as well as the spiritual advantages of his conversion. Three thousand of his followers immediately followed his example, and were baptized. On one occasion, upon hearing the narrative of Christ's sufferings, crucifixion, and death, he is said to have been so deeply moved as to exclaim, "Had I been present at the head of 
my valiant Franks, I would have revenged His chap. xx. wrongs."

By his great victory over the Roman Governor conquest of Syagrius, Clovis became master of that part of France lying between the Rhine and Seine. His next aim was the conquest of Burgundy, in the south-east. It was ruled by his wife's uncle, and the murderer of his wife's father. The Burgundian King was an Arian, whilst Clovis was a Catholic. The Burgundians were thus divided on religious grounds in their allegiance. The Catholic section, friendly to Clovis, prevailed, and Burgundy came under the dominion of the Franks. Clovis then directed his attention to the central parts of Gaul. There the Arian Goths had for some time been intermingled with the older population. It grieved the soul of Clovis to see these Arian Goths in possession of the richest parts of the country. His soldiers urged him on against them, and to conquer or die. He hurled his battle-axe upon the ground. "There," said he, "will I erect a home in honour of the holy Apostles."

$\mathrm{He}$ marched from Paris to Tours, and there victory over visited the tomb of St. Martin of Tours had become noted for their miraculous healing power. The messengers, who were sent on before the King, were told to listen, 
CHAP. xx. as they entered the Church of Tours, to the particular words that were being chanted. They happened to be those which recount the glorious exploits of Old Testament warriors. This was regarded as a good omen, and he was encouraged to make an attack upon the Goths. The decisive battle was fought and won at Poitiers, A.D. 508. The victors continued their march south, as far as the Ebro in Spain. He was honoured by the Roman Emperor, as the conqueror of Gaul, with the title of Consul, and was crowned at Tours as the monarch of Gaul. It was thus that the kingdom of the Franks was first established in Gaul.

The Vase of Soissons.

The Pope a temporal suvereign.
The Frankish Kings found it necessary to share with their nobles not only the toils, but also the trophies of war. When, on one occasion, the spoils were laid out for distribution, and Clovis begged for himself a vase belonging to the Church of Rheims, the army assented; but one of his chiefs, striking it with his battle-axe, exclaimed, "You shall have nothing here but what falls to your share by lot." Nevertheless Clovis quietly appropriated the coveted vase.

The family of Clovis ruled in France under the name of Merovingians, from Meroveus, the grandfather of Clovis, for two hundred years; but they rapidly declined in power, which fell into the 
hands of leading nobles or mayors, called Mayors chap. xx. of the Palace, who usurped all regal authority, and finally the regal title. The most powerful were Charles Martel, Pepin, and Charlemagne. Charles Martel had conquered the Frisians of Holland, and had turned the tide of Mahometan conquest in the south. His son Pepin obtained the power, and assumed the title of King of the Franks. He checked in Italy the conquests of the Lombards, who were threatening another sack of Rome. At the earnest solicitation of the Pope, Pepin warded off the danger, drove back the Lombards, and confined them to northern Italy, known as Lombardy. The provinces thus delivered belonged to the Exarch of Ravenna, who was the Viceroy of the Emperor at Constantinople. These provinces were now bestowed by Pepin upon the Pope, who for the first time became a temporal sovereign.

Pepin, who had rendered this great service to The Pope the Pope, was by him served in return. The $\begin{gathered}\text { confers the } \\ \text { cropn on } \\ \text { Pepin. }\end{gathered}$ house of Clovis still ruled in name the territories won by the Franks; but all power was in the hands of Pepin. With the Pope's sanction, the feeble representative of that house was dethroned and sent into a monastery; while Pepin was crowned King of the Franks, first by Boniface, the Apostle of Germany, and a missionary from 
Chap. xx. England, then by Pope Stephen III. Thus the Bishops of Rome claimed and exercised the power of dethroning princes, and of absolving subjects from their oaths. The Franks, now released from their old masters of the Merovingian house, raised Pepin on a buckler, as the sovereign of a free people.

The forged After Pepin, by his victories over the Lombards
will of will of
Constantine. and his spoliation of the Empire, had formed a temporal dominion for the Pope, the Pope himself studiously denied that he was under any obligation to Pepin, and asserted that his territory had been bequeathed to him by the will of Constantine the Great. A will had been forged, and was now produced, to prove a grant, not only of the city of Rome and the Exarchate of Ravenna, but of the whole western half of the Empire.

Bishops of Rome the alleged sucThe story told said that Constantine had been cossors of anstantine. and, in gratitude, had retired from Rome, and healed of a leprosy in the water of his baptism, made the new city of Constantinople his capital ; moreover, he had resigned to the Popes the perpetual sovereignty of Rome, Italy, and the West of Europe. The Greek Emperors who had afterwards ruled in the West were therefore usurpers, and the gifts of Pepin of what were named the Papal States were but acts of just restitution. The Bishops of Rome had now established not 
only their successorship of St. Peter in spiritual cHAP. xx. authority, but of Constantine in their temporal sovereignty.

Italy was thus torn from the Lombards by the Charlemagne superior arms of Pepin; and also from the Icono- authority clast Emperors, with whom the Pope was at war and Italy. on the question of images, and conferred on the Pope. But the connection of Rome with the Empire was not wholly severed. The Bishop of Rome wished to have in reserve a power which, if necessary, he might use against the master spirit of the Frankish kings. On the other hand, after the victories over the Lombards, Charlemagne refused to make an absolute surrender of the rights or prerogatives in Rome and Italy which he and his father had acquired by the success of their arms. He therefore counted Rome amongst his capital cities, and maintained his imperial title over the west.

The Popes had all the advantages of hereditary ddrantage princes in a steady and continuous policy, com- over other bined with those of a free and popular election. They were generally men of great ability and popularity, of ripe age and experience. Every new Pope, at his election, was reminded that he would not reach the twenty-five years' reign of St. Peter. It was the boast of Hadrian I. that he had saved Rome, secured the patrimony of 
CHAP. xx. St. Peter, ruined the Lombards, and made a friend of Charlemagne.

The pilgrim. age to Rome.

And yet the election of a Pope was occasionally stained with the darkest crimes. Leo III., the successor of Hadrian, was assailed by a band of conspirators, the friends of a rival candidate. $\mathrm{He}$ is said to have lost, by the knife of an assassin, both eyes and tongue, which he miraculously recovered. Charlemagne sympathised with him, invited him to his Court, promised to visit him in return at Rome, in the following year. This pilgrimage of Charlemagne, as it was termed, was made A.D. 800. It was the feast of Christmas when he appeared in the Church of St. Peter, and exchanged the simple dress of his own nation for that of a Roman patrician. After Mass had been sung, Leo placed on his head a rich crown. The voice of the congregation at the same time rose in acclamation, "Long life and victory to Charles Augustus, crowned by God, the great and pacific Emperor of the Romans."

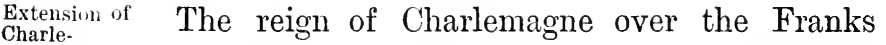
masne's dominion. reached from A.D. 768 to 814 . It was during the latter half of this reign, from the time that he was crowned Emperor of the West, that he extended his dominion over the whole of Germany, as far as the Vistula, and along the Danube as far as its junction with the Save. His position had been 
well established by the victories of his father and chap. xx. grandfather. He was able to leave the territories which he had received from them in the care of his faithful vassals, and break up fresh ground. His victories over the Gerrnan tribes were so many victories for Christianity. Wherever he planted his standard he extirpated idolatry, and established Christianity. Eight new Bishoprics were founded in different parts of Germany. After many sanguinary battles, Bohemia was added to his crown. The Huns were subjugated to his rule, and Pannonia became a province of the West.

It may have been that he spared the Greek The pirates Empire out of regard for the sovereign, who for of the North. the first time was a female, whom it was said Charlemagne proposed to marry. Many of the Saxons and Northmen, who would not submit to the Eranks, nor embrace Christianity, fled back to Denmark or Scandinavia, or betook themselves to piracy. Their fleets scoured the sea around the coasts of Europe and Britain, and filled the next two centuries with the tales of their ravages.

It was a principle with the Frankish Kings to divide their territory amongst their children, and, as far as possible, make a settlement before their death. For this purpose, Charlemagne required 
CHap. xx. his eldest son, Lewis, to take the crown from the The division altar, and place it upon his own head. The sons
of the king. dom. of Lewis were required to do the same, each crown representing the portion of the Empire which the father had assigned to them. Their coronations were afterwards sanctioned and repeated by the Pope. This division of the Empire divided the family, and soon caused its decay; while the influence of the Bishops of Rome rose higher and higher, so that they deposed almost at will the heirs of the great prince.

The cruel barbarism of Great conquerors are seldom free from the dark the agse. stains of cruelty and barbarism. Notwithstanding his zeal for Christianity, Charlemagne had nine wives; he murdered the infant children of his brother, Carloman, with whom he had shared his father's inheritance; he slew some remaining princes of the Merovingian race; he beheaded more than 4500 Saxons on one spot. But it was too much a habit of the time to adopt Christianity in name, and remain in ignorance of its spirit and principles. Christ's religion had spread widely, but superficially. There had not been time for the seed to take any deep root, nor was the soil of much depth.

Charlemagne did much for its extension, and with the best intention. Hallam says: "Of his Capitularies, only one is said to have been made 
in the General Assembly of the people; the rest chap. xx. are enacted in Synods of Bishops, and all, without The exception, relate to merely ecclesiastical affairs." of charleThese Capitularies, or laws, tended greatly to increase the power of the clergy, for whose piety and knowledge the Emperor had great respect. They prohibited temporal magistrates from entertaining complaints against the children of the Church. The exemption of the clergy from civil process and judgment had begun under the Emperor Justinian. The Kings of the Franks extended the jurisdiction of Bishops over all causes in which the clergy were concerned. The Bishops themselves were absolutely exempt from secular jurisdiction, and the exemption was extended by Charlemagne to the whole body of the clergy. He, however, reserved for himself the supremacy in all matters civil and ecclesiastical. It was by his own exclusive order that nothing was to be read in churches of doubtful authority. After his vigorous reign ended, there was a violent reaction under his eldest son and successor, Lewis, who tried to walk in the steps of his father, but ended his days in a monastery.

Towards the end of the eighth century there appeared, under the name of Isidore, what have $\underset{\text { The False }}{\text { Decretals. }}$ been long known as the False Decretals. They purported to be the Decrees of the Popes from the 
Chap. xx. time of the Apustles. They take away the power of Metropolitans over Suffragan Bishops, and direct that their appeals be made to the Bishops of Rome. They allow no erection of new sees, no translation of Bishops until they have been first submitted to, and sanctioned by, the Popes. But there were Metropolitans, and notably Hincmar, Archbishop of Rheims, who boldly resisted these encroachments of Papal power.

Sehools for the study of the Arts.
To Charlemagne is due the legalising, by civil statute, of the collection of tithes for the maintenance of the clergy, the relief of the poor, and the repair of churches. He was the great founder of schools for the study of grammar and logic, music and astronomy; and for their management he invited the assistance of the most famous scholars, and amongst them was the learned Alcuin from England. In the words of Gibbon, "The dignity of his person, the length of his reign, the prosperity of his arms, the vigour of his government, and the reverence of distant ages, distinguish him from the royal crowd; and Europe dates a new era from his restoration of the Western Empire." 


\section{CHRONOLOGICAL INDEX.}

\begin{tabular}{|c|c|}
\hline B. C. & \\
\hline 1058 & Samuel the Prophet died. \\
\hline 838 & Elisha the Prophet died. \\
\hline $760-698$ & Isaiah the Prophet. \\
\hline $606-536$ & Daniel the Prophet and Babylonian Empirc. \\
\hline $536-333$ & Persian Empire. \\
\hline $336-323$ & Alexander the Great. \\
\hline $333-31$ & Greek Empire. \\
\hline 333 & Battle of Issus. \\
\hline 332 & $\begin{array}{l}\text { Siege and capture of Tyre; submission of Jerusalem } \\
\text { and Jews. }\end{array}$ \\
\hline $55 \cdot 54$ & Julius Caesar's Invasions of Britain. \\
\hline 44 & $\begin{array}{l}\text { Assassination of Julius Casar, who is succected } \\
\text { by Augustus. }\end{array}$ \\
\hline 31 & Battle of Actium ; Roman Empire begins. \\
\hline 4 & Birth of Jesus Christ. \\
\hline A. D. & \\
\hline $14-37-41$ & $\begin{array}{l}\text { Tiberius and Caligula, Roman Emperor's ; Apostolic } \\
\text { Labours and Travels. }\end{array}$ \\
\hline 29 & $\begin{array}{l}\text { Death, Resurrection, Ascension of Jesus Christ; } \\
\text { Descent of the Holy Ghost. }\end{array}$ \\
\hline $41-54$ & $\begin{array}{l}\text { Claudius, Roman Emperor; Apostolic Labours and } \\
\text { Travels. }\end{array}$ \\
\hline $54-68$ & $\begin{array}{l}\text { Nero, Roman Emperor; Apostolic Labours and } \\
\text { Travels. }\end{array}$ \\
\hline 68 & Martyrdom of St. Peter and St. Paul. \\
\hline
\end{tabular}


A. D.

69-79-81-96

70

98-117

99

135

138-161-180

165

$177-200$

185-197

193-211

220

248-258

249-251

253

253-257

269

286-306

287-291

292-306

303

305-311

306-312

306-337

312-323

314

315-340

323

325

326-373

329

$337-340$

337-350

337-361

$337 \cdot 342$
Vespasian, Titus, Domitian, Roman Emperors; Labours of St. John.

Destruction of Jerusalem.

Trajan, Roman Emperor.

St. John died.

Revolt of Barcochebas.

Antoninus Pius and Marcus Aurelius, Roman Emperors.

Justin Martyr's Martyrdom.

Irenæus, Bishop of Lyons.

Victor, Bishop of Rome.

Severus, Roman Emperor.

Tertullian, Presbyter and Apologist.

Cyprian, Bishop of Carthage.

Decius, Roman Emperor.

Death of Origen.

Stephanus I., Bishop of Rome.

Anatolius, Bishop of Laodicea.

Diocletian and Maximian, Roman Emperors.

Carausius, Emperor of Britain.

Constantius I., Roman Emperor.

Martyrdom of St. Alban.

Galerius, Roman Emperor.

Maxentius, Roman Emperor.

Constantine the Great, Roman Emperor.

Licinius, Roman Emperor.

Council of Arles.

Eusebius, Bishop of Cæsarea.

Battle of Adrianople.

First General Council.

Athanasius, Patriarch of Alexandria.

Transfer of Roman Capital from Rome to Constantinople.

Constantine II., Roman Emperor of Central Pro. vinces.

Constans, Roman Emperor of the West.

Constantius II., Roman Emperor of the East.

Eusebius, Bishop of Nicomedia. 
A.D.

348-374 350-367

351-360

361-363

364-378

374-397

375-392

379

379-395

381

385-412

390

395-408

395-423

396-430

397-407

399-450

402-417

410

412-444

418-448

419-451

420

422-432

425-455

428-431

429-449

430

431

432-465

434-453

440-461

451

452

481-511

486
Ulphilas, Bishop and Apostle of the Goths.

Hilary, Bishop of Poitiers.

Macedonius, Patriarch of Constantinople.

Julian the Apostate, Roman Emperor.

Valens, Roman Emperor.

Ambrose, Bishop of Milan.

Valentinian II., Roman Emperor.

Gregory Nazianzen, Patriarch of Constantinople.

Theodosius the Great, Roman Emperor.

Second General Council.

Theophilus, Patriarch of Alexandria.

Massacre at Thessalonica.

Arcadius, Roman Emperor of the East.

Honorius, Roman Emperor of the West.

Augustine, Bishop of Hippo.

Chrysostom, Patriarch of Constantinople.

Theodosius the Younger, Roman Emperor of the East.

Innocent I., Bishop of Rome.

Sack of Rome and Death of Alaric, King of the Goths.

Cyril, Patriarch of Alexandria.

Germanus, Bishop of Auxerre.

Theodoric, King of the Visigoths.

Death of Jerome.

Celestine I., Bishop of Rome.

Valentinian III., Roman Emperor of the West.

Nestorius, Patriarch of Constantinople.

Hilary, Bishop of Arles.

Theodore, Bishop of Mopsuestia.

Third General Council and Mission of Palladius.

Patrick, Bishop, and Apostle of Ireland.

Attila, King of the Huns.

Leo 1., Bishop of Rome.

Fourth General Council ; Battle of Chalons.

Destruction of Aquileia.

Clovis, King of the Franks.

Battle of Soissons. 


\begin{tabular}{|c|c|}
\hline A. D. & \\
\hline $492-496$ & Gelasius, Bishop of Rome. \\
\hline 507 & Clovis visits the Shrine of St. Martin. \\
\hline 508 & Battle of Poitiers. \\
\hline $527-565$ & Justinian, Roman Emperor of the East. \\
\hline 533 & Death of Remigius, Bishop of Rheims. \\
\hline 553 & Fifth General Council. \\
\hline $563-597$ & Columba, first Abbot of Iona. \\
\hline $590-604$ & Gregory I., Bishop of Rome. \\
\hline $590-615$ & $\begin{array}{l}\text { Columban, Apostle of Burgundy, Helvetia, and } \\
\text { Lombardy. }\end{array}$ \\
\hline $597-604$ & Augustine, first Archbishop of Canterbury. \\
\hline 601 & Death of David, first Bishop of St. David's. \\
\hline $604-619$ & Laurentius, Archbishop of Canterbury. \\
\hline $609-632$ & Mahomet, the False Prophet; Conquest of Arabia. \\
\hline $610-641$ & Heraclius, Roman Emperor of the East. \\
\hline 616 & Death of Ethelbert, King of Kent. \\
\hline $613-616-633$ & Edwin an Exile, and King of Northumbria. \\
\hline 622 & Hegira. \\
\hline $625-638$ & Honorius I., Bishop of Rome. \\
\hline $625-644$ & Paulinus, first Archbishop of York. \\
\hline $632-634$ & Abu-bekr, Caliph, succeeds Mahomet. \\
\hline $633-639$ & Mahometan Conquest of Syria. \\
\hline $634-644$ & Omar, Caliph. \\
\hline $634-642$ & Oswald, King of Northumbria. \\
\hline $\begin{array}{l}638-647-709 \\
646\end{array}$ & $\begin{array}{l}\text { Mahometan Conquest of Egypt and North Africa. } \\
\text { Felix, Bishop of East Anglia, died. }\end{array}$ \\
\hline $34-651-661-664$ & Aidan, Einan, Colman, Bishops of Lindisfarne. \\
\hline 654 & Penda, King of Mercia, slain. \\
\hline $655-661$ & Ali, Caliph. \\
\hline $657-672$ & Vitalian, Bishop of Rome. \\
\hline $664-709$ & Wilfrid, Archbishop of York. \\
\hline 664 & Synod of Streneshalc. \\
\hline $668-685$ & Constantine IV., Roman Emperor. \\
\hline $668-690$ & Theodore, Archbishop of Canterbury. \\
\hline $642 \cdot 670$ & Oswy, King of Northumbria \\
\hline 673 & Synod of Hertford. \\
\hline 674 & Biscop Benedict builds Monastery of Jarrow. \\
\hline 680 & Synod of Hatfield. \\
\hline
\end{tabular}




\begin{tabular}{c|l} 
A.D. & \\
681 & Sixth General Council. \\
$685-687$ & Cuthbert, successor of Boisil, Abbot of Melrose. \\
$688-716$ & Ceolfrith, Abbot of Jarrow. \\
690 & Death of Biscop Benedict. \\
696 & Willibrod, first Archbishop of Utrecht. \\
$709-714$ & Mahometan Conquest of Spain. \\
714 & Death of Pepin Heristal. \\
$715-731$ & Gregory II., Bishop of Rome. \\
$715-765$ & Boniface, Bishop, and Apostle of Germany. \\
$717-741$ & Leo III., Roman Emperor of the East. \\
732 & Defeat of the Saracens at Tours. \\
735 & Death of Venerable Bede. \\
$741-775$ & Constantine v., Roman Emperor of the East. \\
$750-768$ & Pepin, King of the Franks. \\
$752-757$ & Stephen III., Bishop of Rome. \\
754 & A so-called Seventh General Council (Iconoclast). \\
$771-800$ & Charlemagne, King of the Franks. \\
$772-775$ & Hadrian I., Bishop of Rome. \\
787 & Another so-called Seventh General Council. \\
$788-803$ & Irene, Roman Empress. \\
794 & Council at Frankfort. \\
$795-816$ & Leo III., Bishop of Rome. \\
$800-814$ & Charlemagne, Roman Emperor of the West. \\
$814-840$ & Lewis the Pious, Roman Emperor of the West. \\
&
\end{tabular}




\section{INDEX.}

A.

ABgarus, Christ's alleged reply to the epistle of, 188.

Abila, Christians defeated at, 181.

Abu-bckr, succeeded Mahomet, 165, $171,172,175$.

Abu Obeidah took Damascus, 150 .

Abyssinians, defeated in Arabia, 162 .

Adrianople, battle of, 46 .

Etius, defeats Attila, 146.

Africa, North, Christians of, subdued by Saracens, 175 .

Aidan, St., life and labours of, 114. 121.

Aizneddin, Christians lefeated at, 179.

Alaric, King of Goths, 77 ; sack of Rome, 86-88, 144.

Alban, St., martyrdom of, $29,30,68$; miracles of, 97 ; as a cleparted saint his assistance sought, 102.

Alchfrid, obtains land for monastery at Ripon, 121, 122.

Aleppo, taken by Saracens, 183.

Alexander the Great, capture of Tyre and Jerusalem, 141-143.

Alexandria, a seat of learning, 54, 55; Athanasius, Bishop of, persecuted, 61 ; its importance, 65 ; its capture by Saracens, 184, 185.

Ali, viziel of Mahomet, 165, 166 .

Ambrose, St., ehosen Bishop of Milan, 79 ; resists the Arians, 80,81 ; excommunicates Emperor Theodosius, 82, 83; supposed author of hymn "Te Deum," 84,85 .

Amrou, conquests of, 170, 179, 184, 185.

Anastasia, Gregory Nazianzen preaches in the, 78 .

Anatolius, Paschal canons of, 125.

Andrew, relics of, 100.

Angles and Saxons invited to Britain, 68; Mission of Angustine to, 69 ; form a Heptarchy, 118 .
Antinous, divine honours to, 32,33 .

Antoninus Pius, received favourably Justin Martyr's A pology, 32-35.

Antrim, St. Patrick's labours in, 201.

Apologies of Justin Martyr and Ter. tullian, 32,33 .

Apostles, the labours and travels of, 4 ; their writings, 19.

Aquileia, siege and destruction of, $147,148$.

Arabia, Mahomet's conquest and conversion of, 162, 163.

Arianism, opposed by St. Athanasius, $55-60$; imposed on Ulphilas by Emperor Valens, 76-80 ; of Burgundy, 213.

Arius, Presbyter of Alexanüria, 54; his teaching and condemnation, 129.

Arles, Council at, 68; Bishop of, receives Augustine, consecrates him, 70,73 .

Army, Ronian, distribution of, 7 ; its relief of Orleans, 146.

Articles of Religion, vi., 20 ; xxii., 99 ; xi., 102.

Athanasius, St., at the Council of Nicea, 56, 57; Bishop of Alexandria, 58 ; conflicts with Arians, and banishments by the Emperor, 58-62.

Attila, King of the Huns, 145; de. manded Honoria, 145; ravarged Gaul and Italy, 146-148; treaty of Leo I., 149.

Augustine, St., opponent of Pelagians, 23 ; baptized by Ambrose, 84; his warning from the sack of Rome, 89 ; belief in relics, 100.

Augustine, his mission to Britain, 70 ; reception by King Ethelbert, 71,72 ; instructions from Gregory 1., 73,74 .

Aurelius, Marcus, persecution of, 25 ; apology addressed to, $32 ;$ his letter to the Senate, 37. 
B.

BAMBORoUGH, capital of Northumbrian kings, 121.

Barcochebas, sedition of, 33.

Baptism of King Edwin, 109.

Bede, the Venerable, relates miracles in Britain, 97 ; referred to in support of relics, 100 ; relates prediction of Aidan, 120 ; lived and died in monastery of Jarrow, 160.

Beruicia, northern division of Northumbria, 112.

Bertha, Christian Queen of Kent, 71 ; worships in the Church of St. Martin, 72.

Biscop Benedict, minister of Oswy, 157 ; builds Monastery of Jarrow, $15 \mathrm{~S}$.

Bishops, chief officers of every church, 63; canons respecting, 138.

Blandina, martyrdom of, 25-27.

Bohemia, conquered by Charlemagne, 219.

Boisil, Abbot of Melrose, 154.

Boniface, St., Apostle of Germany, 216.

Bozrah, siege and capture of, 1\%8.

Bregenz, labours of St. Columban at, 209.

Britain, Carausius, Emperor of, 44, 45 .

Britons, ancient, description of, 5 .

Brunehaut, persecutions of Columban by, 208 .

Burgundy, conquest of by Clovis, 213.

Byzantium, taken by Constantine, 46 .

\section{C.}

CAABA, 163.

Cadwalla, slays Edwin, 110 ; is slain by Oswald, 112.

Casar, Julius, invasions of Britain by, 2,3 .

Cæsarea, capture of, $] 83$.

Cairo, capture of, 184 .

Canons of Council at Hertford, 137.

Canterbury, Augustine first Arclbishop of, 73 .

Capitularies of Charlemagne, 220, 221.

Carausius, Emperor of Britain, assassinated, 44.

Cassivellaunus, defeat of, 3 .

Catholics, 213.

Celestine $\mathbf{~}$. sends Palladius to Ireland, 200.
Celibacy of Clersy, 113.

Ceolfrith, Abbot of Jarrow, 160.

Cerinthus, heresy of, 16.

Chad, St., at Council of Streneshalc, 122 ; as Bishop of Lichfield, adopts Roman custom of Easter, 127.

Chalcedon, Council at, 131, 134.

Chalons, battle at, 147 .

Charlemagne, coronation by the Pope, 194, 218; supports the Papacy, 211 ; asserts his supremacy, 217 ; extends his dominion towards the East, 220; legislation of, 221 , 222.

Charles Martel, defeats the Saracens, 150, 178, 215; extends missions in Frisia, 151; friend of Papacy, 193.

Christ, controversies respecting, 129. 133.

Christianity, confusion of with Judaism, 10-14; opposition of Paganism, 23,24 ; its existence threatened, 150 ; its conquests in Ireland, 199, 200.

Christians, persecution of, 47 ; under Moslem rule, 175, 176.

Chrysostom, St., Bishop of Constantinople, 90 ; Libanius, his tutor, 91 ; opposition to, 93 ; banishment, exile, and death, 93-95.

Church, in Rome, 4 ; constitution of, 8,9 ; establishment of, 42 ; prosperity of, $48-52$; always triumphant in the end, 140; God is with her, 149; in Ireland, 198200.

Church, Roman, modelled from the Empire, 64.

Churches, British and Anglo-Saxon, conflicts between, 111 .

Clovis, King of Franks, 150; victories of, 212-214.

Coifi, priest of Edwin, 107 ; destroys idolatry, 108.

Constans, Athanasius at the Court of, 59,60 .

Constantine the Great, establishes Christianity, 17; becomes sole master of Empire, 45, 46, 47 ; brings joy to the Church, 48, 49; overthrow of Maxentius, 50,51 ; calls a Council, 129; forged will of, 216 .

Constantine II., short reign of, 59 , 60.

Constantine Iv. (Pogonatus), calls a Council, 129.

Constantine v., calls a Council, 191, 196. 
Constantinople, opposed to Rome, 65; Council at, 78; Gregory Nazianzen, Bishop of, 78 ; Chrysostom, Bishop of, 90 ; relics removed to, 100; Councils at, 134; assaulted by Iconoclasts, 192.

Constantius, opponent of Athanasius, and friend of Arians, 59-61.

Colman, at Streneshalc, 122 ; resigns his see, 127 .

Columba, founds monastery of Iona, 114; Apostle of Northern Picts, 115 ; his custom of Easter, 125.

Columban, founds monastery of Luxeuil, 207 ; persecuted by Brunehaut, 208; labours in Helvetia and Italy, 209-212.

Cornelius, the Centurion, 12.

Coroticus, piracy of, 201.

Corruptions in the Church, 173.

Councils at Jerusalem, 12; General, $23,66,129$; at Hatfield, 133 ; a Seventh (so-called) 191.

Crisces, accuser of Justin Martyr, 35.

Crosses, at Bozrah, 179.

Custom, British and Roman respecting Easter, 126.

Cuthbert, Abbot of Melrose, 154; Bishop of Lindisfarne, 155 .

Cyprian, Bishop of Carthage, appeal to, 66 .

Cyril, Patriarch of Alexandria, presides at Council, 131, 135.

\section{D.}

Damascus, capture of, 176,179 ; st. John of, 192.

Danai, settle in Denmark, 150.

Daniel, the Prophet, 143.

Darius III., Codomannus, King of Persia, overthrown, 141.

David, St., first Bishop of st. Davill's opposes Pelagianism, 23.

Decius, persecution of, 25 .

Deira, southern division of Northumbria, 112.

Diocletian, persecution of, 25 ; his birth and government, 42.

Docetæ, heresy of, 16 .

Donatists, sclism of, 54 .

Druids, religious rites of, 5 ; of Ireland, 203.

Dundrum Bay, barn of st. Patrick, near to, 203.

E.

EANFleda, becomes wife of Oswy, 120.

Eanfrid, succeeds Edwin in Bernima, 112.
Easter, controversy, 66, 122-12i, 137 .

Edwin, finds a refuge with Redwald, 103; his vision, 104; conncil, 107 ; is baptized, 109 ; spreads Christianity by help of Paulinus, 110.

Erypt, conquest of, 175, 184.

Elisha, the Prophet, 99.

Empire, Roman, a preparation for Christianity, 6, 10; Christianity established in, 42 .

Ephesus, Council at, 131, 134.

Essex, Bishop of, 137 .

Ethelbert. King of Kent, 71 ; receives Augustine's mission, 72 ; the letter and presents of Gregory 1. to, 74 .

Eudoxia, reproved by Chrysostom, $92,93$.

Eusebius of Cæsarea, History of, 41, 42.

Eusebius, of Nicomedia, consecrated Ulphilas, $\pi 6$.

Eutropius invited Chrysostom to Constantinople, 91.

Eutyches, heresy of, 129-132.

F.

False Decretals, 22.2.

Felix, Bishop of East Angles, $10 \%$.

Finan, Bishop of Lindisfarne, 121.

Frankfort, Council at, 197.

Frankish kings, a principle of, 219.

Franks, settlement in Gaul, 149.

Frisians, settlement in Holland, 150 ; their conversion, 151.

\section{G.}

Gabriel, the Angel, said to liave appeared to Mahomet, 163, 169, 171 .

Galerius, persecution of, 43 ; overthrown by Constantine, 45,46 .

Gall, St., companion of Columban, $209,210$.

Gaza, capture of, 141.

Gelasius, Papal claims by, 67 .

Germanus, opposes Pelagianisn, 23, 68 ; miracles of, 97, 95; Patrick, companion of, 202.

Gerizzim, Samaritan temple built on, 142.

Gibbon, admires Athanasius, 61 ; Gregory Nazianzen, 79 ; Ambrose, 83.

Gnostics, heresy of, 17, 18 .

Goths, defeat Valens, $75-77$; overrun Italy, 86-90; in alliance with Romans, 144, 146; Arianisin of, 213. 
Greeks, overthrow Persian empire, 143 ; power of, passes to Latins, $193,195$.

Gregory r., sends mission to Britain, 68-74; instituted Gregorian Chant, 158.

Gregory 11., letter of, to Emperor Leo III., 194.

Gregory Nazianzen, Patriarch of Constantinople, 78 .

H.

HADRIAN, Emperor, his treatment of Christians, 33, 34, 38.

Hadrian, Abbot of St. Peter's, Canter. bury, 136.

Hadrian I., Pope, the boast of, 217.

Hallam, description of Leo the Great by, 67 .

Hashem, family of Mahomet, 163.

Hatfield, Synod at, 133, 134.

Hegira, 166.

Helena, mother of Constantine, 44.

Heliopolis, capture of, 181 .

Heptarchy, 11 .

Heraclius, contests of, 16s, 171.

Herebert, visits Cuthbert, 156 .

Heresies, of Simon, 14; Merander, 15 ; Cerinthus, Docetæ, Ebionites, 16; Manicheans, Valentinians, Gnostics, 17 ; Pelagians, 21.

Hertford, Synod at, 137 .

Hewald, missionaries to Old Saxons, 151.

Hexham, battle at, 112.

Hilary of Arles, deposition threat. ened, 67 .

Hilda, Abbess of Streneshalc, at Council of Streneshalc, 122 ; adopts Roman custom, 127.

Holmpatrick, first converts of Patrick here, 202.

Honoria, demanded in marriage by Attila, 145, 147.

Honorius, succeeds Theodosius, 86 ; resides at Ravenua, 87 .

Honorius, Bishop of Rome, a Monothelite, 132.

Huns, an Asiatic tribe led by Attila, 75,76 ; ravages of, in Gaul and Italy, 144-150.

\section{I.}

ICoNoctasts, led by Emperor Leo the Isaurian, 190; Council of, 191; success of, 195, 196.

1 mages, forbidden by Holy Scripture, 186; origin of, 188 ; destruction of, 190 .
Innocent r., demands to be consulted on all Church matters, 67.

Iona, Monastery of, founded, 114, 115; its supply of missionaries, 154.

Ireland, introduction of Christianity into, 200.

Irenæus, Bishop of Lyons, a writer against heresy, 39; opposed to Victor, Bishop of Rome, 66.

Irene, favours inıage-worship, 196.

Islam, doctrine and discipline of, 164 .

Issus, battle at, 142 .

\section{J.}

JADDUA, meets Alexander, 141.

James the Deacon, 110 ; at the Council of Streneshalc, 122.

Jarrow, Monastery of, founded by Biscop, 157-160.

Jerome, the Monastery of, at Bethlehem, $8 \%$.

Jerusalem, Christianity begins at, 1, 10 ; destruction of, 12-14; relics brought to, 101 ; visit of Alexancler, 142.

Jews, mingled with Christians, 13, 14; favoured by Alexander, 142; persecution of, 169 .

John, St., meets Cerinthus, 16 ; his Easter custom, 124.

Julian, the Apostate, $61,78$.

Justin Martyr, Apologies of, 32, 33, 35.

Justinian, summons Fifth General Council, 129.

K.

KExt, Anglo-Saxon Church spreads thence, 118.

Khoreish, Arab tribe of Mecca, 16:, 168,169 .

Kirkpatrick, 201.

Koran, 164.

\section{L.}

LATINS, increasing power of, 193, 195.

Laurentius, vision of, 102.

Leo the Great, influence of, 66,67 ; meets Attila, 148,149.

Leo IIt., Emperor, an Iconoclast, receives letter of Gregory II., 194.

Leo Iv., Emperor, an Iconoclast, 195.

Leo III., Bishop of Rome, conspiracy against, $21 \mathrm{~S}$.

Lewis, succeeded Charlemagne, 220.

Libanius, 91.

Licinius, defeat of, 46.

Lincoln, Cathedral of, 110 . 
Lindisfarne, Aidan, Bishop of, 114; Nestorius, Patriarch of ConstantiFinan, 121 ; Cuthbert. 154.

Lombards, 215.

Lombardy, Columban and his companions labour in, 210.

Luke, St., relics of, 100 .

Lupus, companion of Gernianus, 23, 68,202

Luxeuil, Monastery of, 20 s.

Lyons, Church of, 25.

M.

Macedonius, heresy of, 129, 134.

Mahomet, his mission to the Arab nation, 162-174; and to the world, $187,189$.

Manasseh, High Priest of Samaritan Temple, 141.

Manuscripts of Holy Scripture, 19.

Marcian, summons Fourth General Council, 129.

Maserfield, battle at, 118.

Maxentius, Emperor, 45 ; overthrown by Constantine, 50,51 .

Maximian, colleague of Diocletian, 43.

Mayo, 204.

Mayors of the Palace, 215.

Mecea, Mahomet born and labours at, $162,166$.

Medina, Mahomet labours and buried there, 172.

Melrose, Abbey of, 154,

Melchites, 184.

Memphis, capture of, 184.

Menander, heresy of, 15.

Mercia, 118; Bishop of, 137.

Meroveus, 214.

Metz, capture of, 146 .

Milan, Edict of, 53 ; residence of Valentinian III., 80 .

Miracles of the Gospels, 96 ; of Bede's History, 97 .

Missions of Gregory r., 68.

Monasteries, description of, 113 ; Iona, 152-154; Irish, 205, 206.

Monks, rule respecting, 138 ; defenders of images, 192.

Monophysites, heresy of, 130, 132.

Monothelites, heresy of, 130, 132 .

Moslems, 167, 176, 177 .

Mosque, 183.

Munster, 204.

Mystery of Christ, 129.

N.

NERo, persecution of. 25, 37 .

Nestorians, heresy of, 131. nople, 129-134.

Nicea, Councils at, 49, 57, 134, 196.

Ninian, St., Apostle of Southern Picts, 115.

Nortlimen, 219.

Northumbria, labours of Paulinus in, 109 ; division of, 112 ; kingdom of Heptarchy, 118; Wilfrid, Bishop of, 137 .

\section{O.}

Omar, third Caliph, 172, 182.

Ordinances of Religion restored, 49 , 50.

Origen, 39.

Orleans, siege of, 146.

Ostrogoths, march on Constantinople, 90.

Oswald, victory of, 112 ; sends for a Bishop, 114 ; receives Aidan, 115 ; sanctity of, 119,120 .

Oswy, succeeds Oswald, 120 ; presides at Council, 122 .

\section{P.}

Paganism, decline of, 4 .

Palladius, mission of, 200.

Pannonia, conquest of, 219.

Pantheon becomes a Christian Church, 24.

Passover begins the Easter of st. John, 124.

Patrick, St., life and labours of, 201-205.

Paul, St., at Rome, 65 ; Epistle of, $66^{\circ}$; iniracles of, 97 ; appears in a vision, 102; circumcision of Timothy, 124; teaches Godhead of Christ, 130.

Paulinus, Bishop of York and Rochester, $105-110$; introduces Gregorian music, 158 .

Pelagius, heresy of, $21,22,68$.

Pella, refuge of Christians, 13.

Penda, slays Edwin, 110; Eanfrid, 112 ; Oswald, 118.

Pepin d'Heristal, 150.

Pepin the Short, crowned King of the Franks, 194, 210.

Persecutions, at Lyons, 25 ; failure of, 27 ; benefit of, 28 ; in Britain, 29, 30.

Persia, 174.

Persian Empire overtlırown, 143.

Peter, St., martyrdom of, 4 ; vision of, 11; alleged first Bishop of Rome, 65, 66; appears in a vision, 102 ; custom of Easter, 124. 
Picts, conversion of, 112 ; receive Oswald, 112; receive Columba, 114.

Pliny the Younger, 38.

Poitiers, battle at, 214.

Popes, assume title of Universal Bishop, 63-65; their defence of images, 193, 194; favourable circunistances of, 217 .

Proconsuls, 46.

Prophecy of Isaiah, 1, 2; of Aidan 121.

\section{R.}

RADBOD, 151.

Ravenna, residence of Honorius, 87 ; of Greek Exarchs, 193, 195, 196.

Redwald, receives Edwin, 103; reinstates him, 105; half Christian, half Pagan, 109.

Regular, 113.

Relics, virtue attributed to, 99, 119, 120.

Remy, St., baptized Clovis, 212.

Ripon, Monastery of, 122 .

Rochester, Bishop of, 137.

Romanus, 178.

Rome, sack of, 86-89; tombs of, 100.

\section{S.}

SAINTS, relics of, 101, 102.

Samaritans, 142 .

Samuel, relics of, 100 .

Sanballat, 141.

Scots, 201.

Scriptures, Holy, copies of, 18-20; Councils bound by, 133, 135.

Sebert, succeeds Redwald, 109.

Secular, 11 s.

See, Roman, daughter Churches of, 135.

Senate, Roman, 46.

Severus, persecution of, 25.

Simon Magus, arch-heretic, 15.

Sophia, St., Cathedral of, 92 .

Sophronius, delivers up Jerusalem, 182.

Spain, Mahometan conquest of, 175 , 185.

Steplianus I., appealed to, 66 .

Stephen, St., relics of, 101.

Stephen III., crowns Pepin, 216.

Streneshalc, Synod at, 122.

Syagrius, defeat of, 213 .

Synods required, 138.

Syria, capture of, 174, 175.
T.

TARA, 203.

Tarik, conquests of, $17 \mathrm{~s}$.

Te Deum, origin of, 84,85 .

Tertullian, apology of, $32,36,39$.

Theodore, presides at Hatfield, 133 ; his primacy, 136 ; presides at Hertford, 137.

Theodoric, King of Goths, in alliance with Romans, 147.

Theodorus of Mopsuestia, heresy of, $130,132$.

Theodosius the Great, Govermment of, 77-83; summoned Second General Council, 129.

Theodosins the Younger, 95 ; summons the Third General Council 129.

Theophilus, opposition to Chrysostom, 92,93 .

Thessalonica, massacre at, 82 .

Thomas, Governor of Damascus, 179 181.

Thurificati, 44.

Thuringian Forest, 147.

Tiberius, reference to the Senate, 37 .

Timothy, relics of, 100 .

Tonsure, 113.

Tours, slirine of, 202, 213.

Traditores, 44.

Trajan, tolerance of, 38 .

Tyre, capture of, 141.

\section{U.}

Ulphilas, Apostle and Bishop of the Goths, 75,76 .

Union of Christians, 36 ; of Church, 139.

Unitarians, 53.

Utrecht, 151.

V.

VALENs, banishes Athanasius, 61 .

Valentinian ri., opponent of Ambrose, 80,81 .

Valentinian III., friend of Leo I., 66 ; brother of Honoria, 145.

Vase of Soissons, 214.

Vespasian, tolerance of, 38.

Victor 1., his threat of excommunication of all Churches, 66 .

Vienne, Church of, 25.

Visigoths, 89.

Visions of Laurentius, 102 ; of Edwin, $103,104$.

Vitalian, appoints Archbishop Theodore and Abbot Hadrian, 136. 
W.

WESSEx, 118.

Wilfrid, tutor of Alchfrid, 121; at Streneshalc, 122; at Hatfield, 133; at Rome, 133; Bishop of Northumbria, 137.

Willibrod, Apostle and Bishop of the Frisians, 151.

Woden, 77 .
Y.

YERMUK, battle at, 181.

York, an archbishopric, 73 ; Paulinus, first Bishop of, 105; Cathedral of $109,117$.

Z.

ZEID, 165, 170.

Zug, 209.

PRINTED BY T. AND A. CONSTABLE, PRINTERS TO HER MAJESTY, AT THE EDINBURGH UNIVERSITY PRESS. 


\section{A SELECTION}

FROM THE

\section{Recent Publications}

OF

Messrs. RIVINGTON

WATERLOO PLACE, PALL MALL

LONDON 


\section{Goulburn's Gospels for Sundays.}

Second Edition. Two I'ols. Crown 8vo. $16 s$.

Thoughts upon the Liturgical Gospels for the Sundays, ONE FOR EACH DAY IN THE YEAR. With an Introduction on their origin, history, the modifications made in them by the Reformers and by the Revisers of the Prayer Book, the honour always paid to them in the Church, and the proportions in which they are drawn from the Writings of the four Evangelists.

By Edward Meyrick Goulburn, D.D., D.C.L., Dean of Norwich.

\section{Goulburn's Gospels for Holy Days.}

Crown 8vo. 8 s. $6 d$.

Meditations upon the Liturgical Gospels. For the minor Festivals of Christ, the two first week-days of the Easter and Whitsun Festivals, and the Red Letter Saints' Days. To which is prefixed some account of the origin of Saints' Days, and their Evens or Vigils; of the pruning of the Calendar of the English Church by the Reformers; and of the re-introduction of the Black-Letter Festivals, with separate notices of the Four which were re-introduced in the Prayer-Book of $155^{2}$.

By Edward Meyrick Goulburn, D.D., D.C.L., Dean of Norwich.

\section{Goulburn's Holy Week Lectures.}

Crowe 8vo. 5 s.

Holy Week in Norwich Cathedral; being Seven Lectures on the several Members of the Most Sacred Body of our Lord Jesus Christ. Delivered at Evensong on each Day of the Holy Week in the Cathedral Church of the Holy and Undivided Trinity of Norwich.

By Edward Meyrick Goulburn, D.D., D.C.L., Dean of Norwich.

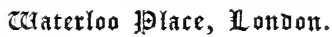




\section{Liddon's Easter Sermons.}

Two Vols. Crozen 8vo. 5s. each. Sold separately.

EAster in St. PAUL's. Sermons bearing chiefly on the Resurrection of our Lord.

By Henry Parry Liddon, D.D., D.C.L., Chancellor and Canon of St. Paul's.

\section{Liddon's Bampton Lectures.}

Eleventh Edition, rezised. Crozen 8vo. 5 s.

The Divinity of our Lord and Saviour Jesus Christ; being the Bampton Lectures for 1866 .

By Henry Parry Liddon, D.D., D.C.L., Chancellor and Canon of St. Paul's.

\section{Liddon's Elements of Religion.}

Fifth and Cheaper Edition. Small 8vo. 2s. 6d. Or in Paper Cover, rs. 6d.

Some Elements of Religion. Lent Lectures.

By Henry Parry Liddon, D.D., D.C.L., Chancellor and Canon of St. Panl's.

The Croun 8wo (Fourth) Edition, 5s., may' still be had.

\section{Liddon's University Sermons.}

Tzuo Vols. Croun 8vo. 5s. each. Sold separately.

Sermons Preached before the University of Oxford.

By Henry Parry Liddon, D.D., D.C.L.,

Chancellor and Canon of St. Paul's.

First Series.-1859-1868.

SeCond Series.-r868-i882.

Uaterloo 招Yace, Rondon. 


\title{
The Altar Book.
}

With Rubrics in Red. Large Type. Royal 8vo. Ios.6d.

The Order of the Administration of the Holy Communion, and THE Form of Solemnization OF MAtrimony, according to the Use of the Church of England.

May also be had bound in Morocco.

\section{À Kempis' Of the Imitation of Christ.}

Large Type Edition. Crown 8vo. 3s. 6d.

Of the Imitation of Christ. In Four Books.

By Thomas à Kempis.

Translated and Edited by the ReV. W. H. Hutchings, M.A., Rector of Kirkby Misperton, Yorkshire.

\section{Knox Little's Hopes of the Passion.}

\author{
Crown 8vo. 3s. 6d.
}

The Hopes and Decisions of the Passion of our Most Holy RedeEMER.

By the Rev. W. J. Knox Little, M.A.,

Canon Residentiary of Worcester, and Vicar of Hoar Cross, Burton-on-Trent.

\section{Newbolt's Man of God.}

Small 8vo. is. 6d.

The MAN of God. Being Six Addresses delivered at the Primary Ordination of the Right Rev. Lord Alwyne Compton, Lord Bishop of Ely, Lent, r886.

By the Rev. W. C. E. Newbolt, M.A., Vicar of Malvern Link.

Waterloo 犾任e, Zondon. 


\section{Woodford's Great Commission.}

Crown 8vo. 5 s.

The Great Commission. Twelve Addresses on the Ordinal.

By James Russell Woodford, D.D., Sometime Lord Bishop of Ely.

Edited, with an Introduction on the Ordinations of his Episcopate, By Herbert Mortimer Luckock, D.D., One of his Examining Chaplains.

\section{Luckock's Bishops in the Tower.}

Crown 8vo. $6 s$.

The Bishops in the Tower. A Record of Stirring Events affecting the Church and Nonconformists from the Restoration to the Revolution.

$$
\begin{aligned}
& \text { By Herbert Mortimer Luckock, D.D., } \\
& \text { Canon of Ely, etc. }
\end{aligned}
$$

\section{The Book of Church Law.}

Fourth Eaition, revised. Crown 8vo. 7s. $6 d$.

THE Book OF ChURCh LAw : being an Exposition of the Legal Rights and Duties of the Parochial Clergy and the Laity of the Church of England.

By the late Rev. John Henry Blunt, D.D.,

Revised by Sir Walter G. F. Phillimore, Bart., D.C.L., Barrister-at:Law, and Chancellor of the Diocese of Lincoln.

Tdaterloo 抑任e, llomoon. 


\title{
Holland's Creed and Character.
}

\author{
Crozen 8z'0. 7 s. $6 d$.
}

Creed And Character. A Volume of Sermons.

By the Rev. H. S. Holland, M.A.,

Canon of St. Paul's.

Contents.

The Story of an Apostle's Faith-The Story of a Disciple's Faith-The Rock ; The Secret; The Fellowship; The Witness; The Resources; The Mind; The Ministry of the Church-The Solidarity of Salvation-The Freedom of Salvation-The Gift of Grace-The Law of Forgiveness-The Coming of the Spirit-1 he Beauty of Holiness-The Energy of Unselfishness-The Fruit of the Spirit-Thanksgiving-The Activity of Service-Character and Circumstance.

\section{Holland's Logic and Life.}

Third Edition. Crown 8vo. 7 s. $6 \mathrm{~d}$.

LOGIC AND LIFE, with other Sermons.

By the Rev. H. S. Holland, M.A.,

Canon of St. Paul's.

'Some of these sermons are as powerful as any preached in this generation, and, indeed, full of genius, original thought, and spiritual veracity. Of the three first, it would be hard to speak in terms too high.'spectator.

- These [two last-named] sermons exhibit at the full the real greatness of Mr. Holland's power-his originality, his insight, his range of experience, observation, and sympatilies : and, above all, his never-failing elevation of spiritual feeling and judgment, speaking in language brilliant, forcible, copious, rising often to splendour and magnificence. Church Quarterly Reviezv.

The sermons are thoughtful, earnest, and often eloquent and powerful. They fully bear out the high reputation Mr. Holland has obtained as a preacher of considerable acceptableness and influence with hearers of education and culture.'-Guaritian.

\section{Holland's Good Friday Addresses.}

Small 8vo. 2s.

GOOD FRIDAY : being Addresses on the Seven Last Words, delivered at St. Paul's Cathedral, on Good Friday I884.

By the Rev. H. S. Holland, M.A.,

Canon of St. Paul's.

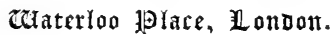




\section{The Missioner's Hymnal.}

Royal $32 m o, 1 d$. Served; $3 \dot{d}$. Cloth Boards.

With Music. Small 4 to. $2 s .6$.

The Missioner's Hymal.

Edited by the Rev. A. G. Jackson,

Wrarden of the Farm School, Redtill, Surrey.

\section{Wakeman's History of Religion.}

Small 8vo. Is. $6 d$.

The History of Religion in England.

By H. O. Wakeman, M.A.,

Fellow of All Souls' College, Bursar, and Tutor of Keble College, Oxford.

\section{Constitutional Essays.}

Crown 8ro. 6s.

ESSAYS INTRODUCTORY TO THE STUDY OF ENGLISH Constitutional History.

By Resident Members of the University of Oxford.

Edited by Henry Offley Wakeman, M.A.,

Fellow of All Souls' College;

And Arthur Hassall, M. A., Student of Christ Church.

\section{Crake’s Church History.}

New Edition. Crown 8vo. $7 s .6 d$.

History of the Church under the Roman Empire, A.D. 30-476.

By the Rev. A. D. Crake, B.A.,

Fellow of the Royal Historical Sociely, Vicar of Cholsey, Berks.

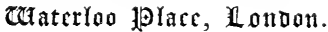




\section{Mercier's By the King and Queen.}

Crown 8vo, with Frontispiece. $2 s$.

By The KING AND QUeEN : A Story of the Dawn of Religion in Britain.

By Mrs. Jerome Mercier, Author of 'Our Mother Church,' etc.

\section{Crake's Chronicles of Æscendune.}

Three Vols. Crown 8vo. 3s.6d.each. Sold separately.

By the Rev. A. D. Crake, B.A.,

Author of the 'History of the Church under the Roman Empire, etc., etc.

EDWy the Fair; OR, The First Chronicle of Æscendune.

A Tale of the Days of St. Dunstan.

Alfgar the Dane; or, The Second Chronicle of æscendune.

A Tale of the Days of Edmund Ironside.

The Rival Heirs; Being the Third and Last Chronicle of ÆSCENDUNE.

\section{Crake's House of Walderne.}

Crown 8 o. 3 s. 6 d.

The House of Walderne: A Tale of the Cloister and the Forest in the Days of the Barons' Wars.

By the Rev. A. D. Crake, B.A.,

Fellow of the Royal Historical Society, Author of the 'Chronicles of AEscendune,' etc.

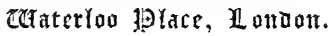




\title{
Mozley on the Old Testament.
}

Third Edition. 8vo. ros. 6d.

RULing IdeAs in EARly Ages and their Relation to Old Testament Faith. Lectures delivered to Graduates of the University of Oxford.

\author{
By J. B. Mozley, D.D., \\ Late Canon of Christ Church, and Regius Professor of Divintity in the \\ University of Oxford.
}

\section{Contents.}

Abraham-Sacrifice of Isaac-Human Sacrifices-Exterminating Wars-Visitation of the Sins of Fathers upon Children-Jael-Connection of Jael's Act with the Morality of her Age-Law of Retaliation-Retaliation: Law of Goël-The End the Test of a Progressive Revelation-The Manichæans and the Jewish Fathers.

\section{Mozley's University Sermons.}

Fifth Edition. Crown 8vo. 7s. 6 .

\section{Sermons Preached before the University of OXford and on VARIOUS OCCASIONS.}

\author{
By J. B. Mozley, D.D.,
}

Late Canon of Christ Church, and Regius Professor of Divinity, Oxford.

\section{Eantents.}

The Roman Council-The Pharisees-Eternal Life-The Reversal of Human Judgment-War-Nature-The Work of the Spirit on the Natural Man-The Atonement-Our Duty to Equals-The Peaceful Temper-The Strength of Wishes-The Unspoken Judgment of Mankind-The True Test of Spiritual Birth-Ascension Day-Gratitude-The Principle of Emulation-Religion the First Choice-The Influence of Dc gmatic Teaching on Education.

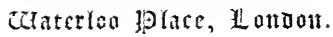




\section{Mozley's Essays.}

Second Edition. Trwo Vols. 8zio. 24 s.

Essays, Historical and Theological.

By J. B. Mozley, D.D.,

Late Canon of Christ Church, and Regius Professor of Divinity in the University of Oxford.

Contents.

Volume I.-Introduction and Memoir of the Author-Lord Strafford-Archbishop Laud-Carlyle's Cromwell-Luther.

Volume II.-Dr. Arnold-Blanco White-Dr. Pusey's Sermon-The Book of Job-Maurice's Theological Essays-Indian Conversion-The Argument of Design-The Principle of Causation considered in opposition to Atheistic Theories-In Memoriam-The Author's Articles and Works.

\section{Mozley on Miracles.}

Seventh Edition. Crown 8vo. 7s. 6 d.

Eight LeCTuRES ON MiRACLES: being the Bampton Lectures for I865.

By J. B. Mozley, D.D.,

Late Canon of Christ Church, and Regius Professor of Divinity in the University of Oxford.

\section{Mozley's Parochial Sermons.}

Second Edition. Crown 8vo. 7s. 6d. Sermons, Parochial and Occasional.

By J. B. Mozley, D.D.,

Late Canon of Christ Church, and Regius Professor of Divinity in the University of Oxford.

contents.

The Right Eye and the Right Hand-Temptation treated as Opportunity-The Influences of Habit on Devotion-Thought for the Morrow-The Relief of Utterance-Seeking a Sign-David Numbering the People-The Heroism of Faith-Proverbs-The Teaching of Events-Growing Worse-Our Lord the Sacrifice for Sin-The Parable of the Sower-The Religious Enjoyment of Nature-The Threefold Office of the Holy Spirit-Wisdom and Folly Tested by Experience-Moses, a Leader-The Unjust Steward-Sowing to the SpiritTrue Religion, a Manifestation-St. Paul's Exaltation of Labour-Jeremiah's Witness against Idolatry-Isaiah's Estimate of Worldly Greatness-The Shortness of Life-The Endless State of Being-The Witness of the Apostles-Life a Probation-Christian Mysteries, the Common Heritage-Our Lord's HourFear-The Educating Power of Strong Impressions-The Secret Justice of Temporal Providence-Jacob as a Prince Prevailing with God. 


\section{Mozley's Lectures.}

8vo. 10s. 6 .

Lectures and other Theological Papers.

By J. B. Mozley, D.D.,

Late Canon of Christ Church, and Regius Professor of Divinity in the University of $O$.rford.

\section{The Prayer Book in Latin.}

With Rubrics in Red. Small 8i'o. 7s. 6 d.

Liber Precum Publicarum Ecclesiæ Anglicanæ.

A Gulielmo Bright, S.T.P.,

Edis Christi apui Oxon. Canonico, Historia Ecclesiastica, Professore Kegro,

et

Petro Goldsmith Medd, A.M.,

Collegii Universitatis apua Oxon. Socio Sentiore.

Latine Redditus. Editio Tertia, cum Appendice.

[In hac Editione continentur Versiones Latinæ-r. Libri Precum Publicarum Ecclesiæ Anglicanæ; 2. Liturgiæ Primæ Reformatæ ; 3. Liturgiæ Scoticanæ; 4. Liturgiæ Americanæ.]

\section{Blunt's Household Theology.}

New Edition. Small 8vo. 3s. 6d.

Housenold Theology : a Handbook of Religious Information respecting the Holy Bible, the Prayer Book, the Church, the Ministry, Divine Worship, the Creeds, etc., etc.

By the Rev. John Henry Blunt, D.D.,

Editor of the 'Annotated Book of Common Prayer,' etc., etc.

Also a Cheap Edition. I6mo. Is.

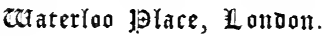




\section{Selections from Liddon.}

Second Edition. Crozen 8vo. 3s. $6 d$.

Selections from the Writings of H. P. Liddon, D.D., D.C.L., Chancellor and Canon of St. Paul's.

Selections from Keble.

Crown 8vo. 3s. $6 d$.

Selections from the Writings of John Keble, M.A., Author of 'The Christian Year.'

\section{Selections from Pusey.}

Second Edition. Crown 8vo. 3s. $6 d$.

Selections from the Writings of Edward Bouverie Pusey, D.D., Late Regius Professor of Hebrew, and Canon of Christ Church, Oxford.

\section{Selections from Neale.}

Crown 8vo. 3s. 6a.

Selections from the Writings of John Mason Neale, D.D., Late Warien of Sackille College.

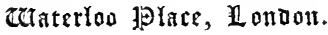




\section{Corpus Christi.}

With Red Borders. Royal $32 \mathrm{mo}$, 25 .

CORPUS CHRISTI: A Manual of Devotion for the Blessed Sacrament.

With a Preface by the Rev. H. Montagu Villiers,

Vicar of St. Paurs, Irilton Place.

Also a Cheap Edition, without the Red Borders, is.

\section{Williams on the Catechism.}

New Edition. Two Vols. Crown 8vo. 5s, each. Sold separately.

Plain Sermons on the Catechism.

By the Rev. Isaac Williams, B.D.,

Late Fellow of Trinity College, Oxford; Author of a "Devotional Commentary on the Gospel Narrative."

\section{Bickersteth's Yesterday, To-day, and For Ever.}

One Shilling Edition. $18 m$.

With Red Borders. I6mo. 2s. $6 d$.

Yesterday, To-dAy, AND For Ever : a Poem in Twelve Books.

\section{By Edward Henry Bickersteth, D.D., Bishop of Exeter.}

- This blank-verse poem, in twelve books. has made its way into the religious world of England and America without much help from the critics. $-T$ imes.

-The most simple, the richest, and the most perfect sacred poem which recent days have produced.'-Morning Advertiser.

- A poem worth reading, worthy of attentive study ; full of noble thoughts, beautiful diction, and high imagination. - Stumdard.

- In these light Miscellany days there is a spiritual refreshment in the spectacle of a man girding up the loins of his nind to the task of producing a genuine epic. And it is true poetry. There is a definiteness, a crispness about it, which in these moist, viewy, hazy days is no less invigorating than novel.' - Edinburgh Daily Reviez.

- Mr. Bickersteth writes like a man who cultivates at once reverence and earnestness of thought.'-Guardian.

The Larger Edition, 5s., may be had.

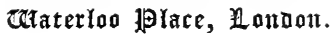




\section{The Annotated Prayer Book.}

In One Volume. Quarto. £r, rs.

Or Half-bound in Morocco. £I, Ixs. $6 d$.

The Annotated Book of Common Prayer : being an Historical, Ritual, and Theological Commentary on the Devotional System of the Church of England.

\section{Edited by the Rev. John Henry Blunt, D.D., F.S.A.}

The reception which the Annotated Book of Common Prayer has met with during an issue of eight editions in sixteen years has led the publishers to believe that a new edition, carefully revised and enlarged, in accordance with our advanced knowledge, would be acceptable. The present edition has therefore been prepared with, among others, the following improvements :-

I. A thoroughly trustworthy text of the whole Prayer Book, such as has not hitherto been accessible.

2. A much enlarged Introduction, embracing in a compact form all that is now known respecting the history of the Prayer Book.

3. The Epistles and Gospels, with all other portions of Holy Scripture, are now printed at length.

4. The Notes on the Minor Saints' Days have been carefully revised, and in most cases re-written.

\section{Maxims from Carter.}

Crown 16mo. $2 s$.

Maxims and Gleanings from the Writings of T. T. Carter, M.A.

Selected and arranged for Daily Use by C. M. S., Compiler of 'Daily Gleanings of the Saintly Life,' 'Under the Cross,' etc.

With an Introduction by the Rev. M. F. Sadler, Rector of Honiton, Deven. 


\section{Luckock on the Prayer Book.}

Second Edition. Crown $8 \mathbf{r}^{\prime}$. $6 s$.

Studies in the History of the Book of Common Prayer.

The Anglican Reform-The Puritan Innovations-The Elizabethan Reaction-The Caroline Settlement. With Appendices.

\section{By Herbert Mortimer Luckock, D.D.,}

Canon of Ely, etc. 'This able and helpful book-recom-
mending it emplatically to all educated
members of the entire Anglican community.'
- Church Quarterly Reviezv.
'We heartily commend this very interest-
ing and very readable book.' - Guardian.
'Dr. Luckock's compact and clearly arranged volume is a valuable contribution to liturgical history, which will prove interesting to all readers and almost indispensable to the theological student who has to master the history and rationale of the Book of Common Prayer.'-Notes and Queries.

\section{Knox Little's Mystery of the Passion.}

Third Edition. Crown 8vo. 3s. 6d.

The Mystery of the Passion of our Most Holy Redeemer.

By the Rev. W. J. Knox Little, M.A.,

Canon Residentiary of Horcester and I icar of Hoar Cross.

\section{The Treasury of Devotion.}

Fourteenth Edition. 18mo, 2s. 6d.; Cloth limp, 2s.; or bound with the Book of Common Prayer, $3 s .6 d$.

The Treasury of Devotion : a Manual of Prayers for General and Daily Use.

Compiled by a Priest.

Edited by the Rev. T. T. Carter, M.A.

Also an Edition in Large Type. Crown 8vo. ${ }_{5}$ s.

CUaterloo jplace, llomon. 


\section{Williams's Female Scripture Characters.}

New Edition. Croun 8vo. 5 s.

Female Characters of Holy Scripture. A Series of Sermons.

By the Rev. Isaac Williams, B.D.,

Formerly Fellow of Trinity College, Oxford.

\section{Contents.}

Eve-Sarah-Lot's Wife-Rebekah-Leah and Rachel-Miriam-RahabDeborah-Ruth-Hannah-The Witch of Endor-Bathsheba-Rizpah-The Queen of Sheba-The Widow of Zarephath-Jezebel-The ShunammiteEsther-Elisabeth-Anna-The Woman of Samaria-Joanna-The Woman with the Issue of Blood-The Woman of Canaan-Martha-Mary-Salome -The Wife of Pilate-Dorcas-The Blessed Virgin.

\section{Blunt's Dictionary of Sects.}

Imperial 8vo. $36 s$; or in half-morocco, 48 s.

Dictionary of Sects, Heresies, Ecclesiastical Parties, and Schools of Religious Thought. By Various Writers.

Edited by the Rev. John Henry Blunt, D.D., Editor of the 'Dictionary of Theology,' 'Annotated Book of Common Prayer,'etc., etc.

\section{Body's Life of Temptation.}

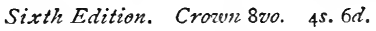

The Life of Temptation. A Course of Lectures delivered in substance at St. Peter's, Eaton Square; also at All Saints', Margaret Street.

By the Rev. George Body, M.A., Canon of Durham.

\section{Contents.}

The Leading into Temptation-The Rationale of Temptation-Why we are Tempted-Safety in Temptation-With Jesus in Temptation-The End of Temptation.

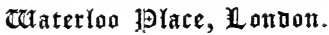




\section{Knox Little's Manchester Sermons.}

Second Edition. Crown 8vo. $7 s .6 d$.

Sermons PREACHed for THE MOST PART in MANChester.

By the Rev. W. J. Knox Little, M.A.,

Canon Resiaentiary of Horcester, and Vicar of Hoar Cross.

\section{Contents.}

The Soul instructed by God-The Claim of God upon the Soul-The Supernatural Powers of the Soul-The Soul in its Inner Life-The Soul in the World and at the Judgment-The Law of Preparation-The Principle of Preparation - The Temper of Preparation-The Energy of Preparation-The Soul's Need and God's Nature-The Martyr of Jesus-The Secret of Prophetic Power-The Law of Sacrifice-The Comfort of God-The Symbolism of the Cross-The Beatitude of Mary, the Mother of the Lord.

\section{Knox Little's Christian Life.}

Third Edition. Crown 8vo. 3s. 6 d.

Characteristics and Motives of the Christian Life. Ten Sermons preached in Manchester Cathedral in Lent and Advent I877.

By the Rev. W. J. Knox Little, M.A.,

Canon Residentiary of Worcester, and Vicar of Hoar Cross.

Contents.

Christian Work-Christian Advance-Christian Watching-Christian BattleChristian Suffering-Christian Joy-For the Love of Man-For the sake of Jesus-For the Glory of God-The Claims of Christ.

\section{Knox Little's Witness of the Passion.}

Crozen 8vo. 3 s. 6،l.

The Witness of the Passion of our Most Holy Redeener.

By the Rev. W. J. Knox Little, M.A.,

Canon Residentiary of llorcester, and Vicar of Hoar Cross.

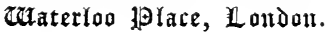




\title{
Williams's Devotional Commentary.
}

New Edition. Eight Vols. Crown 8vo. 5s. each. Sold separately.

A Devotional Commentary on the Gospel Narrative.

By the Rev. Isaac Williams, B.D.,

Formerly Fellow of Trinity College, Oxford.

THOUGHTS ON THE STUDY OF THE HOLY GOSPELS.

A HARMIONY OF THE FOUR EVANGELISTS.

OUR LORD'S NATIVITY.

OUR LORD'S MINISTRY (SECOND YEAR).

OUR LORD'S MINISTRY (THIRD YEAR).

THE HOLY WEEK.

OUR LORD'S PASSION.

OUR LORD'S RESURRECTION.

\section{Voices of Comfort.}

\author{
Sixth Edition. Crown 8vo. 7 s. 6it.
}

VOICES OF COMFORT.

Edited by the Rev. Thomas Vincent Fosbery, M.A.,

Sometime Vicar of St. Giles's, Oxford.

This Volume of prose and poetry, original and selected, aims at revealing the fountains of hope and joy which underlie the griefs and sorrows of life. It is so divided as to afford readings for a month. The keynote of each day is given to the title prefixed to it, such as: "The Power of the Cross of Christ, Day 6. Conflicts of the Soul, Day 17. The Communion of Saints, Day 20. The Comforter, Day 22. The Light of Hope, Day 25. The Coming of Christ, Day 28.' Each day begins with passages of Holy Scripture. These are followed by articles in prose, which are succeeded by one or more short prayers. After these are poems or passages of poetry, and then very brief extracts in prose or verse close the section. The book is meant to meet, not merely cases of bereavement or physical suffering, but 'to minister specially to the hidden troubles of the heart, as they are silently weaving their dark threads into the web of the seemingly brightest life.'

Also a Cheap Edition. Small 8vo. 3s. 6\%.

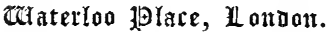




\section{The Star of Childhood.}

Fourti Edition. Royal i6mo. 2s. 6 d.

The StAR OF Childhood : a First Book of Prayers and Instruction for Children.

Compiled by a Priest.

Edited by the Rev. T. T. Carter, M.A.

With Illustrations after Fra Angelico.

\section{The Guide to Heaven.}

New Edition. I8mo. Is. 6 d. ; Cloth limp, is.

The Guide to Heaven : a Book of Prayers for every Want. For the Working Classes.

Compiled by a Priest.

Edited by the Rev. T. T. Carter, M.A.

An Edition in Large Type. Crown 8vo. is. 6d.; Cloth limp, is.

\section{H. L. Sidney Lear's For Days and Years.}

New Edition. I6mo. 2s. $6 d$.

For Days ANd Years. A Book containing a Text, Short Reading and Hymn for Every Day in the Church's Year.

Selected by H. L. Sidney Lear.

Also a Cheap Edition. $32 m o$, is.; or Cloth gilt, is. 6 d.

\section{Williams on the Epistles and Gospels.}

New Edition. Two Vols. Crown 8vo. 5s. each. Sold separately.

Sermons on the Epistles and Gospels for the Sundays

and Holy Days throughout the Year.

By the Rev. Isaac Williams, B.D.,

Author of a 'Devotional Commentary on the Gospel Naw'rative.'

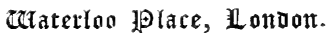




\title{
Moberly's Parochial Sermons.
}

\author{
Crown 8vo. 7s. $6 d$.
}

Parochial Sermons, chiefly preached at Brighstone, Isle of Wight.

\section{By George Moberly, D.C.L.,}

Late Bishop of Salisbury.

\section{Eantents.}

The Night is far spent, the Day is at hand-Elijah, the Warner of the Second Advent of the Lord-Christmas-Epiphany-The Rich Man and Lazarus-The Seventh Day Rest-I will arise and go to my Father-Confirmation, a Revival-Korah-The Law of Liberty-Buried with $\mathrm{Him}$ in Baptism-The Waiting Church of the Hundred and Twenty-Whitsun Day. I will not leave you comfortless-Whitsun Day. Walking after the Spirit -The Barren Fig Tree-Depart from me; for I am a sinful man, O LordFeeding the Four Thousand-We are debtors- - He that thinketh he standeth -The Strength of Working Prayer-Elijah's Sacrifice-If thou hadst known, even thou-Harvest Thanksgiving-Jonadab, the Son of Rechab-The Transfiguration; Death and Glory-Welcome to Everlasting Habitations-The Question of the Sadducees.

\section{Moberly's Plain Sermons.}

New Edition. Crown 8vo. 5s.

\section{Plain Sermons, Preached at Brighstone.}

By George Moberly, D.C.L., Late Bishop of Salisbury.

\section{Contents.}

Except a man be born again-The Lord with the Doctors-The Draw-Net-I will lay me down in peace-Ye have not so learned Christ-Trinity SundayMy Flesh is Meat indeed-The Corn of Wheat dying and multiplied-The Seed Corn springing to new life-I am the Way, the Truth, and the Life-The Ruler of the Sea-Stewards of the Mysteries of God-Ephphatha-The Widow of Nain-Josiah's discovery of the Law-The Invisible World: Angels-Prayers, especially Daily Prayers-They all with one consent began to make excuseAscension Day-The Comforter-The Tokens of the Spirit-Elijah's Warning, Fathers and Children-Thou shalt see them no more for ever-Baskets full of fragments-Harvest-The Marriage Supper of the Lamb-The Last Judgment. 


\section{Luckock's Footprints of the Son of Man.}

Third Edition. Tzuo Vols. Crown 8vo. I2s.

Footprints of the SON OF MAN AS TRACEd by SAINT MARK: being Eighty Portions for Private Study, Family Reading, and Instructions in Church.

By Herbert Mortimer Luckock, D.D., Canon of Ely; Examining Chaplain to the Bishop of Ely; and Principal of the Theological College.

With an Introduction by the late Bishop of Ely.

\section{Goulburn's Thoughts on Personal Religion.} New Edition. Small8zo. 5.. 6d.

Thoughts on Personal Religion: being a Treatise on the Christian Life in its two Chief Elements-Devotion and Practice.

By Edward Meyrick Goulburn, D.D., D.C.L., Dean of Norwich.

Also a Cheap Edition. 3 s. 6 d.

Presentation Edition, elegantly printed on Toned Paper. Two Vols. Sinall 8vo. Ios. $6 d$.

\section{Goulburn's Pursuit of Holiness.}

Seventh Edition. Small 8vo. 5 s.

The Pursuit of Holiness: a Sequel to 'Thoughts on Personal Religion,' intended to carry the Reader somewhat farther onward in the Spiritual Life.

By Edward Meyrick Goulburn, D.D., D.C.L., Dean of Norwich.

Also a Cheap Edition. $3^{s .6 d}$.

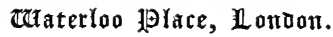




\section{Goulburn on the Lord's Supper.}

Sixth Edition. Small 8vo. $6 s$.

A Commentary, Expository and Devotional, on the Order of the Administration of the Lord's Supper, according to the Use of the Church of England; to which is added an Appendix on Fasting Communion, Non-communicating Attendance, Auricular Confession, the Doctrine of Sacrifice, and the Eucharistic Sacrifice.

By Edward Meyrick Goulburn, D.D., D.C.L., Dean of Norwich.

Also a Cheap Edition, uniform with 'Thoughts on Personal Religion,' and 'The Pursuit of Holiness.' 3 s. $6 d$.

\section{Goulburn's Holy Catholic Church.}

Second Edition. Crown 8vo. 6s.6d.

The Holy Catholic Church: its Divine Ideal, Ministry, and Institutions. A short Treatise. With a Catechism on each Chapter, forming a Course of Methodical Instruction on the subject.

By Edward Meyrick Goulburn, D.D., D.C.L.,

Dean of Norwich.

Contents.

What the Church is, and when and how it was founded-Duty of the Church towards those who hold to the Apostles' Doctrine, in separation from the Apostles' fellowship-The Unity of the Church and its Disruption-The Survey of Zion's towers, bulwarks, and palaces-The Institution of the Ministry, and its relation to the Church-The Holy Eucharist at its successive Stages-On the Powers of the Church in Council-The Church presenting, exhibiting, and defending the Truth-The Church guiding into and illustrating the Truth-On the Prayer Book as a Commentary on the Bible-Index.

Taterfoo 理Yace, london. 


\section{Goulburn's Collects of the Day.}

Third Edition. Two Vols. Crown 8vo. 8s. each. Sold separately.

The Collects of The Day : an Exposition, Critical and Devotional, of the Collects appointed at the Communion. With Preliminary Essays on their Structure, Sources, and General Character, and Appendices containing Expositions of the Discarded Collects of the First Prayer Book of $\mathbf{1 5 4 9}$, and of the Collects of Morning and Evening Prayer.

\section{By Edward Meyrick Goulburn, D.D., D.C.L., \\ Dean of Norwich.}

\section{Contents.}

Volume I. Book I. Introductory.-On the Excellencies of the Collects-On the Origin of the word Collect-On the Structure of a Collect, as illustrated by the Collect in the Burial Service-Of the Sources of the Collects : Of the Sacramentary of Leo, of the Sacramentary of Gelasius, of Gregory the Great and his Sacramentary, of the Use of Sarum, and of S. Osmund its Compiler-On the Collects of Archbishop Cranmer-Of the Restoration Collects, and of John Cosin, Prince-Bishop of Durham-Of the Collects, as representing the Genius of the English Church. Book II. Part 1.-The Constant Collect. Part II.-Collects varying with the Ecclesiastical Season-Advent to Whitsunday.

Volume II. Book II. contd.-Trinity Sunday to All Saints' Day. Book III. - On the Collects after the Offertory. APPENDIx A.-Collects in the First Reformed Prayer Book of 1549 which were suppressed in $1552-$-The Collect for the First Communion on Christmas Day-The Collect for S. Mary Magdalene's Day (July 22). Appendix B.-Exposition of the Collects of Morning and Evening Prayer-The Second at Morning Prayer, for Peace-The Third at Morning Prayer, for Grace-The Second at Evening Prayer, for PeaceThe Third at Evening Prayer, for Aid against all Perils.

\section{Knox Little's Good Friday Addresses.}

New Edition. Small 8vo. 2s.; or in Paper Cover, is.

The Three Hours' Agony of Our Blessed Redeemer : being Addresses in the form of Meditations delivered in S. Alban's Church, Manchester, on Good Friday 1877.

By the Rev. W. J. Knox Little, M.A.,

Canon Residentiary of Worcester, and Vicar of Hoar Cross.

adaterloo 招lace, Lomon. 


\title{
Luckock's After Death.
}

Fifth Edition. Crown 8vo. 6s.

After DeAth. An Examination of the Testimony of Primitive Times respecting the State of the Faithful Dead, and their relationship to the Living.

\author{
By Hërbert Mortimer Luckock, D.D., \\ Canon of Ely, etc. \\ Cantents.
}

PART I.--The Test of Catholicity-The Value of the Testimony of the Primitive Fathers-The Intermediate State-Change in the Intermediate StatePrayers for the Dead: Reasons for Our Lord's Silence on the Subject-The Testimony of Holy Scripture-The Testimony of the Catacombs-The Testimony of the Early Fathers-The Testimony of the Primitive LiturgiesPrayers for the Pardon of Sins of Infirmity, and the Effacement of Sinful Stains-The Inefficacy of Prayer for those who died in wilful unrepented Sin.

ParT II.-Primitive Testimony to the Intercession of the Saints-Primitive Testimony to the Invocation of the Saints-The Trustworthiness of the Patristic Evidence for Invocation tested-The Primitive Liturgies and the Roman Catacombs-Patristic Opinions on the Extent of the Krowledge possessed by the Saints-The Testimony of Holy Scripture upon the same Subject-The Beatific Vision not yet attained by any of the Saints-Conclusions drawn from the foregoing Testimony.

Supplementary Chapters. - (a.) Is a fuller Recognition of the Practice of Praying for the Dead desirable or not?-(b.) Is it lawful or desirable to practise Invocation of Saints in any form or not?-Table of Fathers, Councils, etc. Passages of Scripture explained or quoted-General Index.

\section{S. Bonaventure's Life of Christ.}

Crown 8vo. 7 s. $6 d$.

ThE LifE OF Christ.

By S. Bonaventure.

Translated and Edited by the Rev. W. H. Hutchings,

Rector of Kirkby Misperton, Yorkshire.

- The whole volume Is full of gems and rich veins of thought, and whether as a companion to the preacher or to those who seek food for their daily meditations, we can scarcely imagine a more acceptable book.' -Literary Churchman.

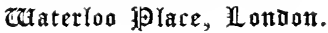




\title{
Newman's Selection from Sermons.
}

Third Edition. Crown 8vo. 5s.

Selection, adapted to the Seasons of the Ecclesiastical Year, from the 'Parochial and Plain Sermons' of John Henry Newman, B.D., sometime Vicar of S. Mary's, Oxford.

\author{
Edited by the Rev. W. J. Copeland, B.D., \\ Late Rector of Farnham, Essex.
}

\section{Contents.}

Advent:-Self-denial the Test of Religious Earnestness-Divine Calls-The Ventures of Faith-Watching. Christmas Day:-Religious Joy. Nezw Year's Sunday:-The Lapse of Time. Epiphany:-Remembrance of Past MerciesEquanimity-The Immortality of the Soul-Christian Manhood-Sincerity and Hypocrisy-Christian Sympathy. Septuagesima:-Present Blessings. Sexa. gesima:-Endurance, the Christian's Portion. Quinquagesima:-Love, the One Thing Needful. Lent:-The Individuality of the Soul-Life the Season of Repentance-Bodily Suffering-Tears of Christ at the Grave of LazarusChrist's Privations a Meditation for Christians-The Cross of Christ the Measure of the World. Good Friday:-The Crucifixion. Easter Day:-Keeping Fast and Festival. Easter-Tide:-Witnesses of the Resurrection-A Particular Providence as Revealed in the Gospel-Christ Manifested in RemembranceThe Invisible World-Waiting for Christ. Ascension:-Warfare the Condition of Victory. Sunday after Ascension:-Rising with Christ. Whitsunday:The Weapons of Saints. Trinity Sunday:-The Mysteriousness of our Present Being. Sundays after Trinity:-Holiness Necessary for Future Blessedness-The Religious Use of Excited Feelings-The Self-wise Inquirer-Scripture a Record of Human Sorrow-The Danger of Riches-Obedience without Love as instanced in the Character of Balaam-Moral Consequences of Single Sins-The Greatness and Littleness of Human Life-Moral Effects of Communion with God-The Thought of God the Stay of the Soul-The Power of the Will-The Gospel Palaces-Religion a Weariness to the Natural Man-The World our Enemy-The Praise of Men-Religion Pleasant to the ReligiousMental Prayer-Curiosity a Temptation to Sin-Miracles no Remedy for Unbelief-Jeremiah, a Lesson for the Disappointed-The Shepherd of our Souls -Doing Glory to God in Pursuits of the World.

Caterloo j⿴囗十ace, London. 


\title{
Early Influences.
}

Crown 8vo. 3s. $6 d$.

EARly Influences. New Edition.

With a Preface by Mrs. Gladstone.

Chapter I.-Infancy. Chapter II.-Watchfulness and Affection. Chapter III. -The Faults of Childhood and the Influence of Religious Instruction. Chapter IV.-Good Impulses and Moral Influence. Chapter V.-Manner and Accomplishments. Chapter VI.-The Mental Powers of Childhood-Instruction in General. Chapter VII.-Home-The Influence of Domestic Life upon the Country in General. Chapter VIII.-The Difficulty and the Reward.

\section{The School of Life.}

\author{
Crown 8vo. 4 s. $6 d$.
}

ThF SchoOL OF LifE. Seven Addresses delivered during the London

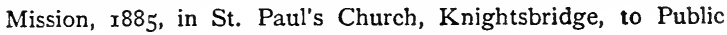
School Men, by late and present Head Masters.

With an Introduction by C. J. Vaughan, D.D.,

Dean of Llandaff and Master of the Temple. Formerly Head Master of Harrow School.

\section{H. L. Sidney Lear's Precious Stones.}

Three Vols. 32mo. Is. each; or in Paper Covers, 6d. each.

Precious Stones, collected by H. L. Sidney Lear.

$$
\begin{aligned}
& \text { I. PEARLS-GRACE. } \\
& \text { II. RUBIES-NATURE. } \\
& \text { III. DIAMONDS-ART. }
\end{aligned}
$$

Also a Superior Edition, 16 mo, with Red Borders, 2s. each.

\begin{abstract}
- Diamonds contains extracts having re. ference to Art. Many will appreciate the beautiful passages from Ruskin; and the carefully chosen thoughts from the writings of Newman, Faber, and Sir Joshua Reynolds will give pleasure. An undercurrent of devotional feeling has guided the choice of these extracts. In Pearls the compiler has taken a wider range. We

Kempis, Bishop Jeremy Taylor, Faber, Newman, Emerson, while one or two reflections fraught with practical wislom have been gathered from Lord Chesterfield. The collection called $R$ ubies contains reflections on Nature from S. Augustine, S. Francis de Sales, and S. Gregory, besides extracts from Ruskin, Neale, Hugh Macmillan, and Charles Kingsley.'-Times.
\end{abstract} find valuable meditations from 7 homas à

An Edition complete in One Volnme, r6mo, with Red Borders, 3 s. 6 d. 


\section{Jennings' Ecclesia Anglicana.}

Crown 8vo. 7 s. $6 d$.

Ecclesia Anglicana. A History of the Church of Christ in

England, extending from the Earliest to the Present Times.

By the Rev. Arthur Charles Jennings, M.A.,

Atsus College, Cambridge, sometime Tyrzhitt Scholar, Crosse Scholar, Hehrezv University Prizeman, Fry Scholar of S. Foln's College, Carus and Scholefield Prizeman, and Rector of King's Stanley,

\section{Bickersteth's The Lord's Table.}

Second Edition. I6mo. xs.; or Cloth extra, $2 s$.

The LORD'S TABLE; or, Meditations on the Holy Communion Office in the Book of Common Prayer.

By E. H. Bickersteth, D.D., Bishop of Exeter.

'We must draw our review to an end, without using any more of our own words, except one parting expression of cordial and sincere thanks to Mr. Bickersteth for this goodly and profitable "Companion to the Communion Service." -Record.

\section{Manuals of Religious Instruction.}

Nezw and Revised Editions. Small 8vo. 3s.6d. each. Sold separately.

MANUALS OF RELIGIOUS INSTRUetion.

Edited by John Pilkington Norris, D.D., A rchdeacon of Bristol and Canon Residentiary of Bristol Cathedral.

I. The Catechism and Prayer Book.

II. The Old Testament.

III. The New Testament.

CUaterlon 细Yace, 边onon. 


\section{Aids to the Inner Life.}

Five Vols. $32 m o$, Cloth limp, 6d. each; or Cloth extra, is. each. Sold separately.

These Five Volumes, Cloth extra, may be had in a Box, price 75 . Also an Edition with Red Borders, 2s. each.

Aids TO THE INNER LIFE.

Edited by the Rev. W. H. Hutchings, M.A., Rector of Kirkby Misperton, Yorkshire.

These books form a series of works provided for the use of members of the English Church. The process of adaptation is not left to the reader, but has been undertaken with the view of bringing every expression, as far as possible, into harmony with the Book of Common Prayer and Anglican Divinity.

OF THE IMITATION OF CHRIST. In Four Books. By Thomas A KEMPIS.

THE CHRISTIAN YEAR. Thoughts in Verse for the Sundays and Holy Days throughout the Year.

INTRODUCTION TO THE DEVOUT LIFE. From the French of $\mathrm{S}$. FrANCIS DE SALES, Bishop and Prince of Geneva.

THE HIDDEN LIFE OF THE SOUL. From the French of JEAN Nicolas Grov.

THE SPIRITUAL COMBAT. Together with the Supplement and the Path of Paradise. By LAurence Scupoli.

- We herrtily wish success to this im. portant series, and trust it may command an extensive sale. We are much struck, not only by the excellent manuer in which the design has been carried out in the Translations themselves, but also by the way in which Messrs. Rivington have done their part. The type and size of the volumes are precisely what will be found most con-

venient for common use. The price at which the volumes are produced is marvellously low. It may be hoped that a large circulation will secure from loss those who have undertaken this scheme for diffusing far and wide such valuable means of advancing and deepening, after so high a standard, the spiritual life.'-Literary Churchmar.

\section{Blunt's Theological Dictionary.}

Second Edition. Imperial 8vo. 42s. ; or in half-morocco, 52s. $6 d$.

Dictionary of Doctrinal and Historical Theology. By Various Writers.

Edited by the Rev. John Henry Blunt, D.D., Editor of the 'Annotated Book of Common Prayer,' etc., etc.

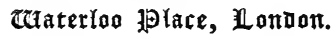




\section{Norris's Rudiments of Theology.}

Second Edition, revised. Crown 8vo. 7s. 6 d.

Rudimen's of Theology. A First Book for Students.

By John Pilkington Norris, D.D., Archdeacon of Bristol, and Canon Residentiary of Bristol Cathedral.

Contents.

Part I.-Fundamental Doctrines:-The Doctrine of God's Existence-The Doctrine of the Second Person of the Trinity-The Doctrine of the Atonement -The Doctrine of the Third Person of the Trinity-The Doctrine of The Church -The Doctrine of the Sacraments.

Part II.-The Soteriology of the Biele:-The Teaching of the Old Testament-The Teaching of the Four Gospels-The Teaching of S. PaulThe Teaching of the Epistle to the Hebrews, of S. Peter and S. John-Soteriology of the Bible (concluded).

Appendix-Illustrations of Part I. From the Early Fathers:-On the Evidence of God's Existence-On the Divinity of Christ-On the Doctrine of the Atonement-On the Procession of the Holy Spirit-On The Church-On the Doctrine of the Eucharist-Greek and Latin Fathers quoted or referred to in this volume, in their chronological order-Glossarial Index.

\section{Medd's Bampton Lectures.}

8vo. I6s.

The One Mediator. The Operation of the Son of God in Nature and in Grace. Eight Lectures delivered before the University of Oxford in the year 1882, on the Foundation of the late Rev. John Bampton, M.A., Canon of Salisbury.

By Peter Goldsmith Medd, M.A.,

Rector of North Cerney; Hon. Canon of S. Alban's, and Examining

Chaplain to the Bishop; late Rector of Barnes; Formerly

Fellow and Tutor of University College, Oxford.

đaterloo 佃依e, Rondon. 


\section{H. L. Sidney Lear's Christian Biographies.}

Eight Vols. Crown 8vo. 3s.6d. each. Sold separately.

Christian Biographies.

Bу H. L. Sidney Lear.

MADAME LOUISE DE FRANCE, Daughter of Louis xv., known also as the Mother Térèse de $\mathrm{S}$. Augustin.

A DOMINICAN ARTIST: a Sketch of the Life of the Rev. Père Besson, of the Order of S. Dominic.

HENRI PERREYVE. By A. Gratry. Translated by special permission. With Portrait.

S. FRANCIS DE SALES, Bishop and Prince of Geneva.

THE REVIVAL OF PRIESTLY LIFE IN THE SEVENTEENTH CENTURY IN FRANCE. Charles de Condren-S. Philip Neri and Cardinal de Berulle-S. Vincent de Paul-Saint Sulpice and Jean Jacques Olier.

A CHRISTIAN PAINTER OF THE NINETEENTH CENTURY: being the Life of Hippolyte Flandrin.

BOSSUET AND HIS CONTEMPORARIES.

FÉNELON, ARCHBISHOP OF CAMBRAI.

\section{H. L. Sidney Lear's Five Minutes.}

Third Edition. 16mo. 3s. 6 d.

Five Minutes. Daily Readings of Poetry.

Selected by H. L. Sidney Lear.

\section{Pusey's Private Prayers.}

Second Edition. Royal $32 m$. 2s. 6 d.

Private Prayers.

By the Rev. E. B. Pusey, D.D.

Edited, with a Preface, by H. P. Liddon, D.D., D.C.L.

Chancellor and Canon of St. Paul's. 


\section{Half-a-Crown Editions of Devotional Works.}

New and Uniform Editions.

Seven Vols. I6mo. 2s. 6d. each. Sold separately.

HALF-A-Crown Editions of Devotional Works.

Edited by H. L. Sidney Lear.

SPIRITUAL LETTERS TO MEN. By ARchbishop FÉnelon.

SPIRITUAL LETTERS TO WOMEN. By ARCHBISHOP FÉNELON.

A SELECTION FROM THE SPIRITUAL LETTERS OF S. FRANCIS

DE SALES, BISHOP AND PRINCE OF GENEVA.

THE SPIRIT OF S. FRANCIS DE SALES, BISHOP AND PRINCE

OF GENEVA.

THE HIDDEN LIFE OF THE SOUL.

THE LIGHT OF THE CONSCIENCE. With an Introduction by the Rev. T. T. Carter, M.A.

SELF-RENUNCIATION. From the French. With an Introduction by the

Rev. T. T. CARTer, M.A.

\section{H. L. Sidney Lear's Weariness.}

Large Type. Fourth Edition. Small 8vo. 5 s.

WEARINESS. A Book for the Languid and Lonely.

By H. L. Sidney Lear,

Author of 'For Days and Years,' 'Christian Biographies,' etc., etc.

\section{Maxims from Pusey.}

Third Edition. Crown 16mo. 2s.

Maxims and Gleanings from the Writings of Edward Bouverie PUSEY, D.D.

Selected and arranged for Daily Use, by C. M. S., Compiler of 'Daily Gleanings of the Saintly Life,' 'Under the Cross,' etc.

With an Introduction by the Rev. M. F. Sadker,

Prebendary of Wells, and Rector of Honiton.

Caaterlon 扔Yare, london. 


\section{Body's Life of Justification.}

Sixth Edition. Crown 8vo. 4s. б́d.

The Life of Justification. A Series of Lectures delivered in substance at All Saints', Margaret Street.

By the Rev. George Body, M.A.,

Canon of Durham.

Contents.

Justification the Want of Humanity-Christ our Justification-Union with Christ the Condition of Justification-Conversion and Justification-The Life of Justification-The Progress and End of Justification.

\section{Keys to Christian Knowledge.}

Seven Volumes. Small 8vo. is. 6d. each. Sold separately. The 2s. 6 d. Edition may still be had.

Edited by the Rev. John Henry Blunt, D.D., Editor of the 'Annotated Bible, 'A nnotated Book of Common Prayer,' etc., etc.

THE HOLY BIBLE.

THE BOOK OF COMMON PRAYER.

CHURCH HISTORY (ANCIENT).

CHURCH HISTORY (MODERN).

CHRISTIAN DOCTRINE AND PRACTICE (founded on the Church Catechism).

Edited by John Pilkington Norris, D.D., Arcindeacon of Bristol, and Canon Residentiary of Bristol Cathedral. Editor of the 'New Testament with Notes,' etc.

THE FOUR GOSPELS.

THE ACTS OF THE APOSILES.

Taterloo j⿴囗十ace, London. 
$1=$ 


\section{Date Due}

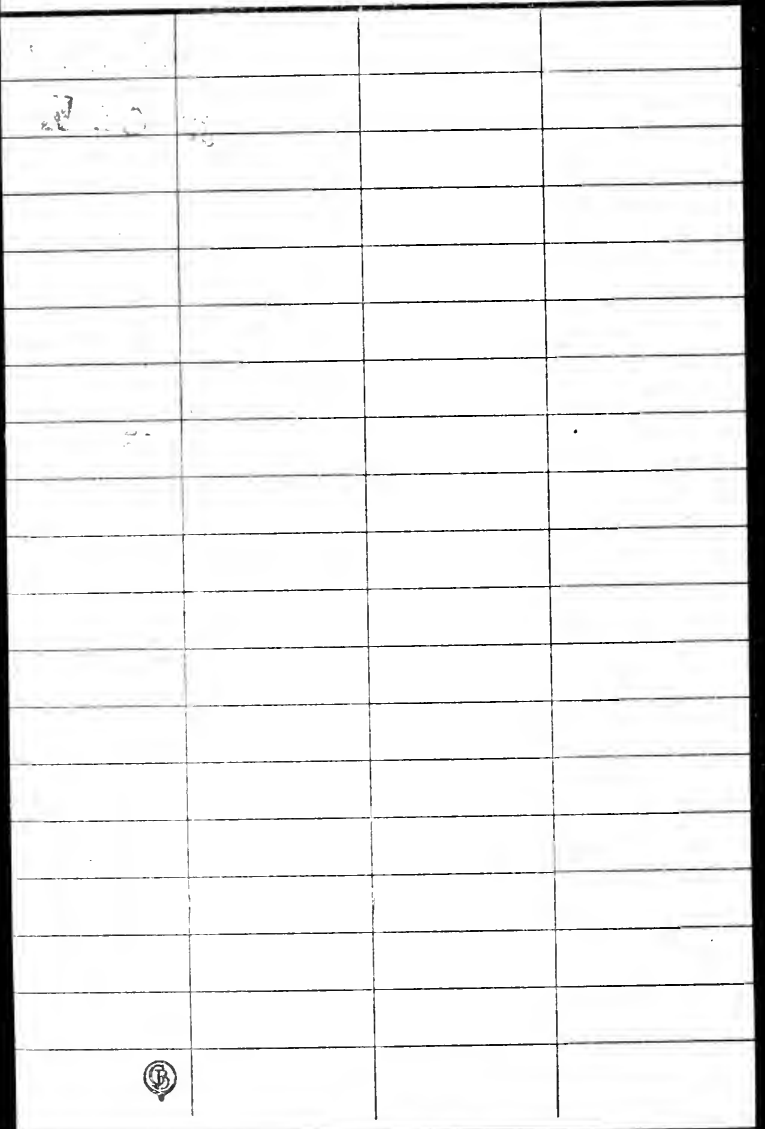



